\title{
SEQUENCE STRATIGRAPHY AND GEOCHEMISTRY OF THE UPPER LOWER THROUGH UPPER TRIASSIC OF NORTHERN ALASKA: IMPLICATIONS FOR PALEOREDOX HISTORY, SOURCE ROCK ACCUMULATION, AND PALEOCEANOGRAPHY
}

by

Landon N. Kelly, Michael T. Whalen, Christopher A. McRoberts, Emily Hopkin, and Carla Susanne Tomsich

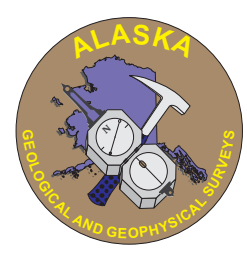

Published by

STATE OF ALASKA

DEPARTMENT OF NATURAL RESOURCES

DIVISION OF GEOLOGICAL \& GEOPHYSICAL SURVEYS 
Report of Investigations 2007-1

\section{SEQUENCE STRATIGRAPHY AND GEOCHEMISTRY OF THE UPPER LOWER THROUGH UPPER TRIASSIC OF NORTHERN ALASKA: IMPLICATIONS FOR PALEOREDOX HISTORY, SOURCE ROCK ACCUMULATION, AND PALEOCEANOGRAPHY}

by

Landon N. Kelly, Michael T. Whalen, Christopher A. McRoberts, Emily Hopkin, and Carla Susanne Tomsich 


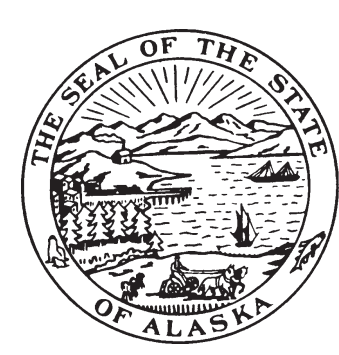

STATE OF ALASKA

Sarah Palin, Governor

DEPARTMENT OF NATURAL RESOURCES

Tom Irwin, Commissioner

DIVISION OF GEOLOGICAL \& GEOPHYSICAL SURVEYS

Robert F. Swenson, State Geologist and Acting Director

Division of Geological \& Geophysical Surveys publications can be inspected at the following locations. Address mail orders to the Fairbanks office.

Alaska Division of Geological

\& Geophysical Surveys

3354 College Road

Fairbanks, Alaska 99709-3707

Elmer E. Rasmuson Library

University of Alaska Fairbanks

Fairbanks, Alaska 99775-1005
University of Alaska Anchorage Library

3211 Providence Drive

Anchorage, Alaska 99508

Alaska State Library

State Office Building, 8th Floor

333 Willoughby Avenue

Juneau, Alaska 99811-0571

This publication released by the Division of Geological \& Geophysical Surveys was produced and printed in Fairbanks, Alaska at a cost of $\$ 5.00$ per copy. Publication is required by Alaska Statute 41, "to determine the potential of Alaskan land for production of metals, minerals, fuels, and geothermal resources; the location and supplies of groundwater and construction materials; the potential geologic hazards to buildings, roads, bridges, and other installations and structures; and shall conduct such other surveys and investigations as will advance knowledge of the geology of Alaska." 


\section{CONTENTS}

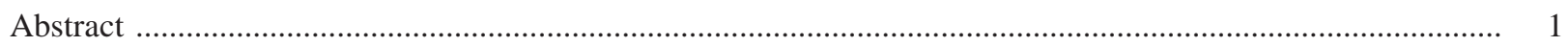

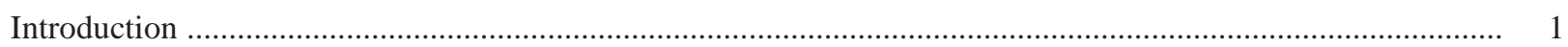

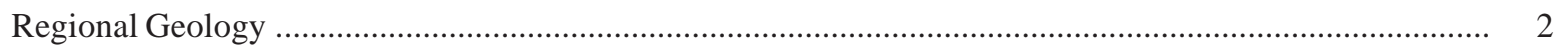

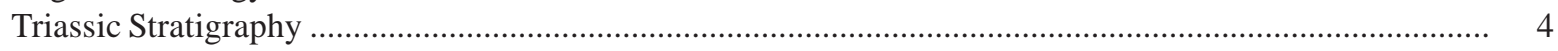

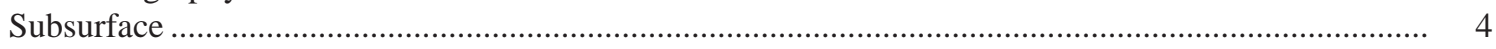

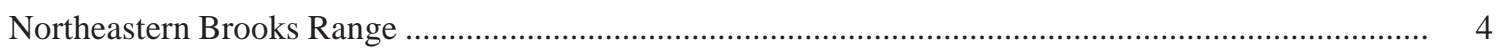

North-central Brooks Range ...................................................................................................................... 7

Previous Sequence Stratigraphic Models ................................................................................................... 7

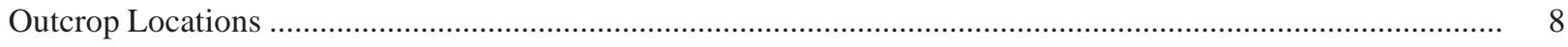

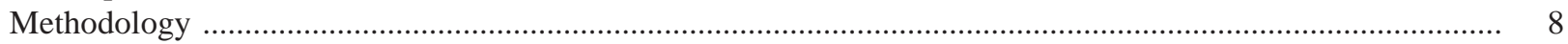

Field Methods ....................................................................................................................................... 8

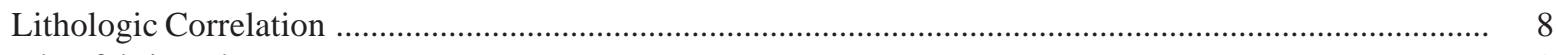

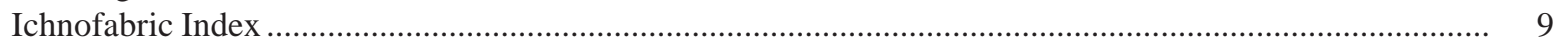

Biostratigraphic Correlation .................................................................................................................... 9

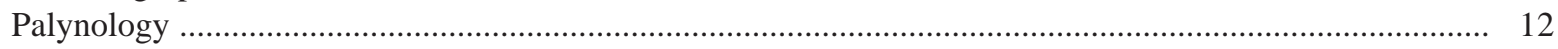

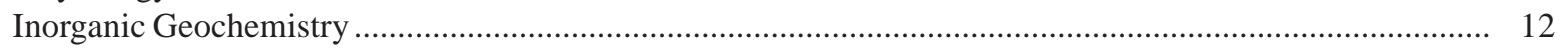

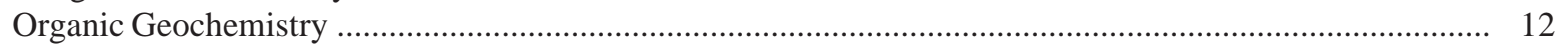

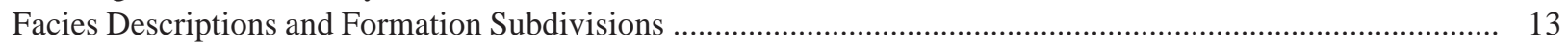

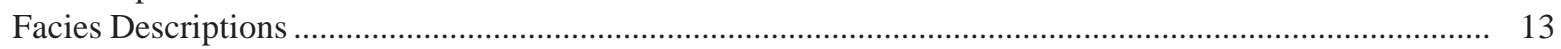

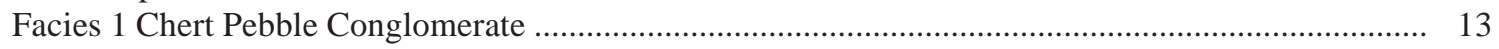

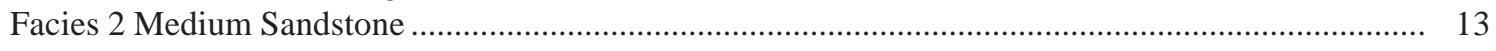

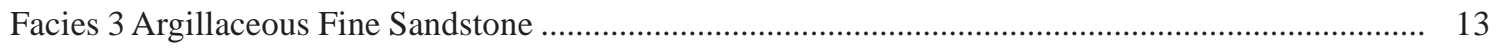

Facies 4 Siltstone

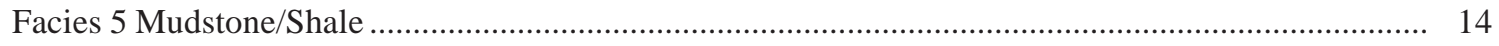

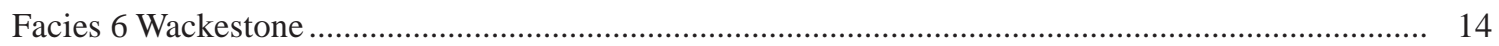

Facies 7 Silty/Argillaceous Limestone or Dolostone ......................................................................... 14

Facies 8 Phosphatic Wackestone and Packstone .................................................................................. 14

Facies 9 Phosphatic Siltstone and Fine Sandstone ............................................................................. 14

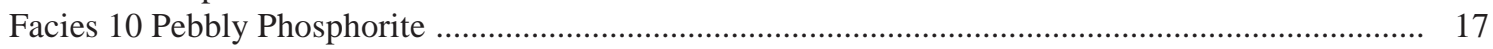

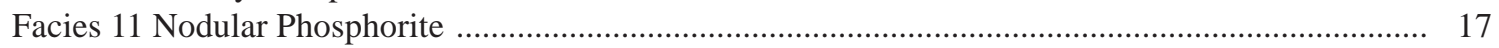

Facies 12 Sandy Phosphorite Facies …………….......................................................................... 17

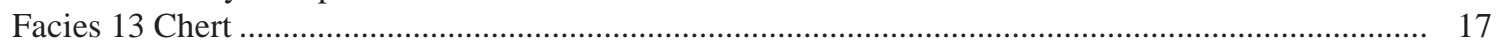

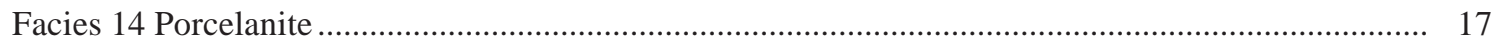

Subdivisions of the Shublik and Otuk Formations …….............................................................................. 17

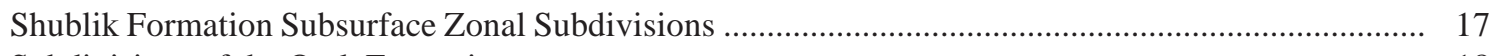

Subdivisions of the Otuk Formation ............................................................................................... 18

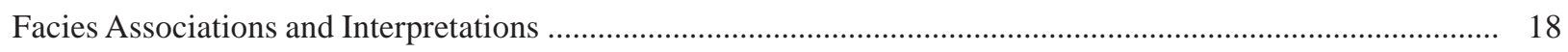

Siliciclastic Retrogradational Facies Association ................................................................................. 22

Siliciclastic, Phosphatic Progradational Facies Association ......................................................................... 22

Mixed Siliciclastic, Carbonate, Phosphatic Retrogradational Facies Association ........................................ 22

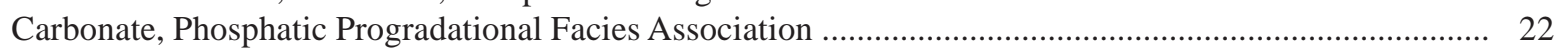

Siliciclastic, Phosphatic Retrogradational Facies Association ...................................................................... 23

Siliciclastic, Carbonate, Phosphatic Progradational Facies Association ................................................... 23

Siliciclastic, Siliceous Retrogradational Facies Association ....................................................................... 23

Siliciclastic, Siliceous Progradational Facies Association ............................................................................ 24

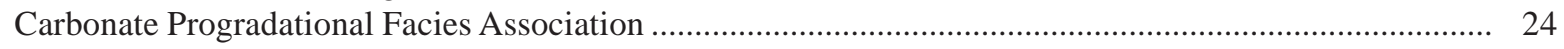

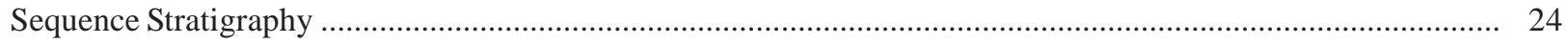

Sequences and Systems Tracts ........................................................................................................ 24

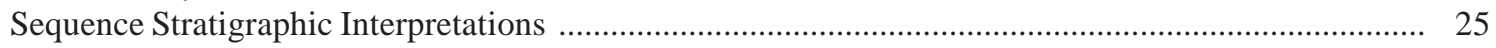

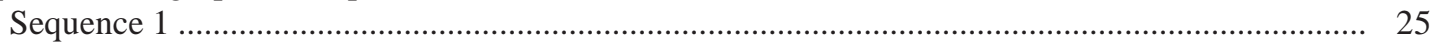

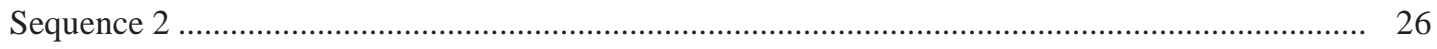

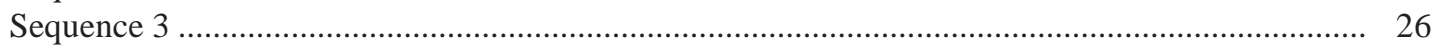




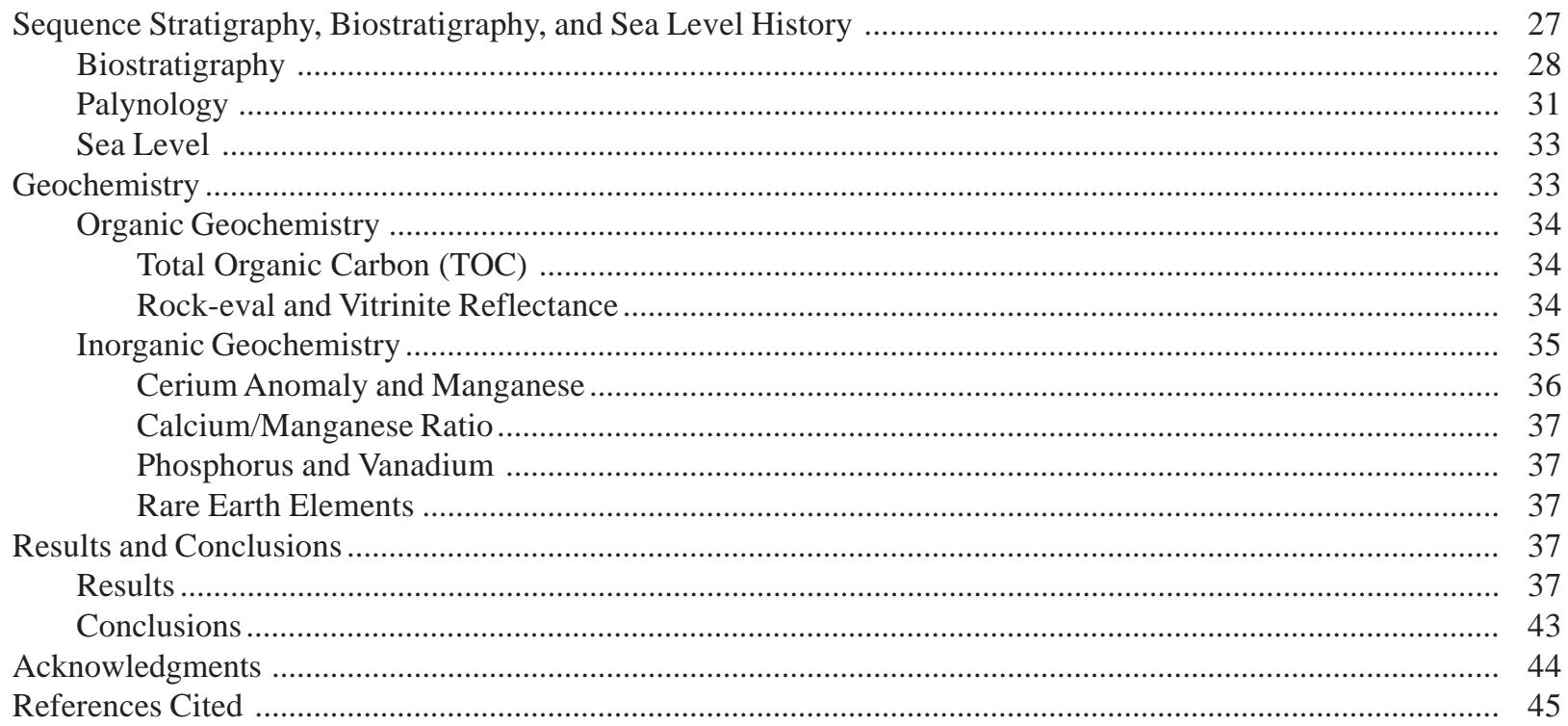

\section{TABLES}

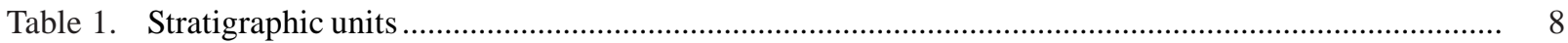

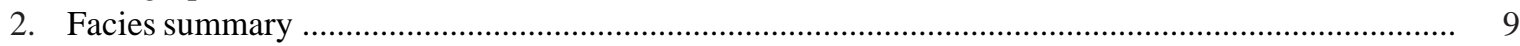

3. Rock-eval and vitrinite reflectance data ............................................................................................ 36

\section{FIGURES}

Figure 1. Map showing distribution of lithofacies and isopachs of Middle and Upper Triassic rocks, northern Alaska

2. Generalized subsurface stratigraphy of northern Alaska

3. Figure showing stratigraphy and gamma ray response of Lower(?) to Upper Triassic rocks exposed at Fire Creek, northeastern Brooks Range .....

4. Photos showing outcrop photographs of upper Lower-Upper Triassic rocks, northeastern and central Brooks Range

5. Photos of lithofacies $1-14$

6. Photos showing sedimentary structures, trace fossils, and megafossils from Triassic rocks of northern Alaska

7. Photos showing ichnofabric of the Shublik and Otuk Formations illustrating varying degrees of bioturbation of different ichnofabric indices (II)

8. Figure showing correlation of sequence one between the lower Otuk Formation at Tiglukpuk Creek and the Fire Creek Siltstone and lower Shublik Formation at Fire Creek.

9. Figure showing correlation of sequence two between the middle Otuk Formation at Tiglukpuk Creek and the lower to middle Shublik Formation at Fire Creek

10. Figure showing correlation of sequence three between the upper Otuk Formation at Tiglukpuk Creek and Atigun Gorge and the upper Shublik Formation at Fire Creek

11. Figure showing sequence stratigraphic correlation of the Shublik and Otuk Formations and related units

12. Photo showing representative and biostratigraphically significant bivalves from the Otuk Formation at Tiglukpuk Creek

13. Figure showing sea level curves for the Triassic period 
14. Figure showing Total Organic Carbon (TOC) trends for the Fire Creek, Atigun Gorge, and Tiglukpuk Creek sections

15. Figure showing Van Krevelen diagram of hydrogen vs. oxygen index for samples from the three study areas

16. Figure showing cerium anomaly and manganese trends and sequence stratigraphic subdivisions for the Fire Creek and Tiglukpuk Creek sections

17. Plots of calcium vs. manganese concentrations and groupings of the elements reflecting the stability of the minerals under varying redox conditions

18. Figure showing phosphorus and vanadium trends for the Fire Creek and Tiglukpuk Creek sections

19. Figure showing stratigraphic distribution of the rare earth elements gadolinium, dysprosium, erbium, and ytterbium in the Fire Creek and Tiglukpuk Creek sections

20. Figure showing schematic diagram depicting coastal upwelling models applicable to northern Alaska during the Triassic

21. Figure showing paleogeographic and paleoceanographic reconstructions for the Late Triassic depicting potential models for marine coastal upwelling 


\title{
SEQUENCE STRATIGRAPHY AND GEOCHEMISTRY OF THE UPPER LOWER THROUGH UPPER TRIASSIC OF NORTHERN ALASKA: IMPLICATIONS FOR PALEOREDOX HISTORY, SOURCE ROCK ACCUMULATION, AND PALEOCEANOGRAPHY
}

\author{
by \\ Landon N. Kelly ${ }^{1}$, Michael T. Whalen ${ }^{1 *}$, Christopher A. McRoberts², \\ Emily Hopkin ${ }^{2}$, and Carla Susanne Tomsich ${ }^{1}$
}

\begin{abstract}
Lower through Upper Triassic rocks in northern Alaska were examined using lithostratigraphic, biostratigraphic, sequence stratigraphic, and geochemical methods to better understand their depositional, paleoredox, and sea level histories; and patterns of source-rock accumulation; and provide insight into Triassic paleoceanography and paleogeography. The uppermost Ivishak and Shublik Formations and Karen Creek Sandstone are exposed in the northeastern Brooks Range and the partially equivalent Otuk Formation in the central Brooks Range. Our analyses provide criteria for subdividing these units into genetic depositional sequences and permit proximal to distal correlations across the Brooks Range. Comparison with previously published subsurface sequence stratigraphy permits surface to subsurface correlations.

Lithostratigraphic, ichnofabric, and geochemical data were collected to assess the temporal variation in paleoredox conditions and the potential for petroleum source-rock accumulation. Trends in facies stacking patterns indicating retrogradational and progradational events were used to define three genetic sequences deposited during the late Early to Late Triassic. Organic geochemical data, including total organic carbon, Rock-eval, and vitrinite reflectance, provide insight into the quality, type of organic matter, and thermal maturity of Triassic source rocks. Shublik source rocks include both marine and terrestrial organic matter, are mature to overmature, and are gas prone. Otuk source rocks are mature and fall within the middle oil to upper wet gas generation maturation fields. Ichnofabric data and sedimentary structures provide evidence of the degree of infaunal sediment reworking and insight into paleoredox conditions. A suite of inorganic geochemical data, including major, trace, and rare earth elements, was gathered to afford additional insight into syn- or early post-depositional paleoredox conditions. The proximal Shublik Formation records fluctuating oxygenation ranging from anoxic to oxic conditions while the more distal Otuk dominantly records oxic and dysoxic environments. We interpret the pattern to indicate the transit of a marine upwelling system during relative sea level change. As the locus of upwelling moved landward during transgressive (retrogradational) events, the associated oxygen minimum zone (OMZ) climbed up the continental shelf and superimposed dysoxic to anoxic deeper-water facies over more oxic shallower water facies. The Otuk Formation records some fluctuations in oxygenation but was probably deposited in deeper environments than the more shoreward impinging OMZ. This paleoceanographic setting was most likely to have formed along a northsouth-oriented shoreline where meridional upwelling was facilitated by southerly alongshore winds. A north-south-oriented shoreline meshes well with the rotational model for Arctic Alaska that calls for approximately $60-70^{\circ}$ of anticlockwise rotation during Mesozoic rifting of the Canada basin.
\end{abstract}

\section{INTRODUCTION}

We present here the results of a study of the Triassic Shublik and Otuk Formations and associated units (figs. 1-3), source rocks that generated much of the oil that accumulated in the Prudhoe Bay field (Bird and Molenaar, 1987; Magoon and Bird, 1988; Bird, 1994). The Shublik Formation was deposited on a gently sloping continental margin under fluctuating oceanic upwelling conditions (Dingus, 1984; Parrish, 1987; Parrish et al., 2001a, b). Modern zones of upwelling are commonly characterized by high primary biologic pro-

ductivity and the associated deposits are defined by a characteristic suite of lithofacies including glauconitic, phosphatic, organic-rich, and cherty sediments deposited from shoreface to basin, respectively (Baturin, 1982, 2000; Parrish, 1982; Thiede and Suess, 1983; Notholt and Jarvis, 1990; Föllmi, 1990; Föllmi et al., 1991). The organic-rich facies are of particular importance because of their source-rock potential. High-resolution correlation rests on a better understanding of the distribution of different rock types and has direct implications for the

\footnotetext{
${ }^{1}$ Department of Geology and Geophysics, University of Alaska Fairbanks, Fairbanks, AK 99775

*Corresponding Author: e-mail - ffmw@uaf.edu

${ }^{2}$ Department of Geology, State University of New York College at Cortland, Cortland, New York 13045
} 


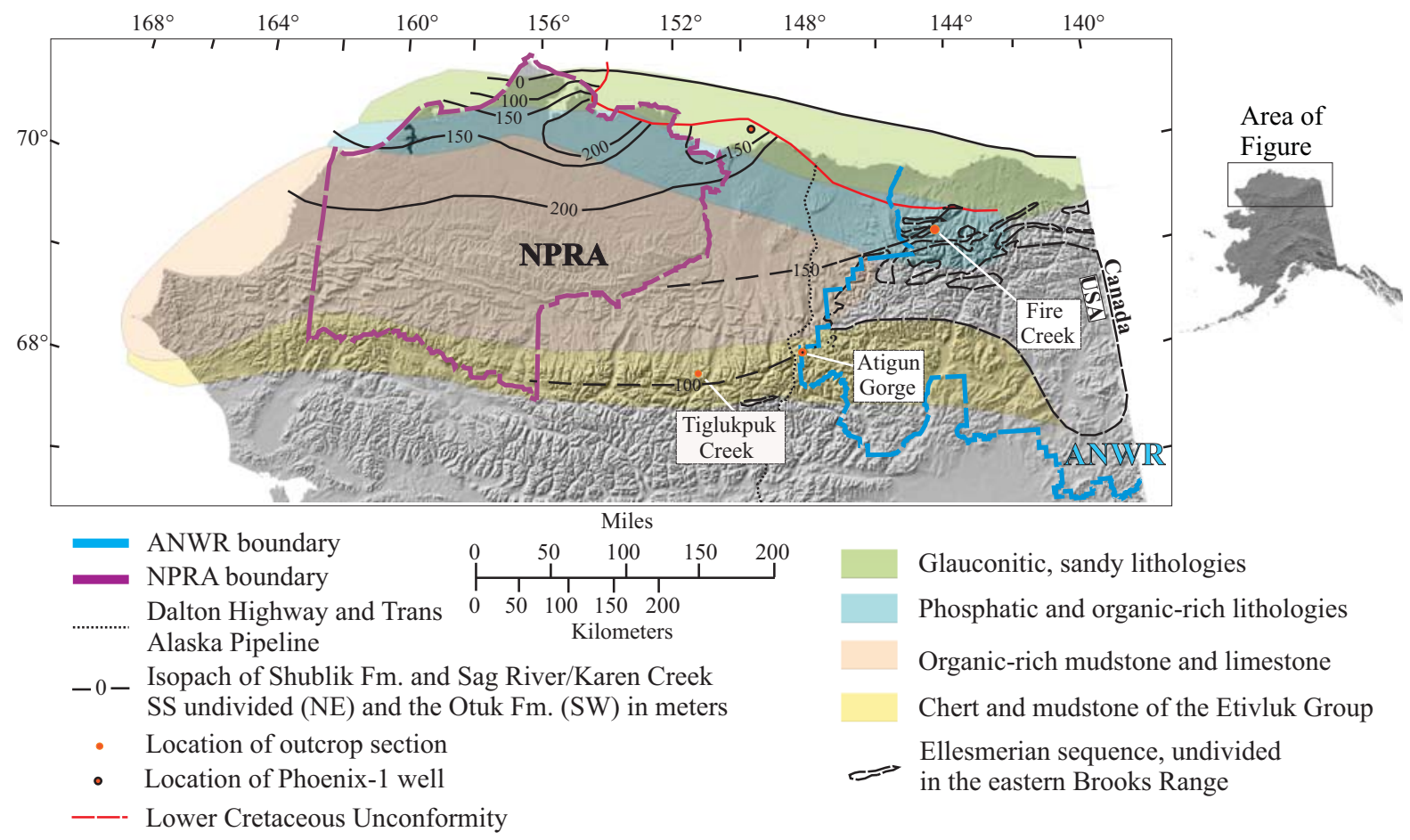

Figure 1. Distribution of lithofacies and isopachs of Middle and Upper Triassic rocks, northern Alaska. Also illustrated are the locations of outcrop sections and the boundaries for the National Petroleum Reserve-Alaska (NPRA) and the Arctic National Wildlife Refuge (ANWR). Modified from Hubbard et al. (1987); Parrish (1987); and Riehle et al. (1997).

source- and reservoir-rock potential of the Shublik and Otuk Formations.

Correlation of upper Lower to Upper Triassic North Slope subsurface units with equivalents exposed in the Brooks Range has only been attempted at the most basic level with a generalized regional correlation across the North Slope (Molenaar et al., 1986). We present a more complete and detailed correlation within a sequence stratigraphic framework. Detailed lithologic and geochemical analyses of the Shublik and Otuk Formations provide a basis for understanding the lateral and vertical distribution of the various upwelling-related facies as well as spatial and temporal variation in the ancient upwelling zone. The methods implemented in this study include detailed examination of the lithostratigraphy, biostratigraphy, chemostratigraphy, ichnofabric, and sequence stratigraphy of distally deposited sediments of upper Lower through Upper Triassic strata in northern Alaska. The sequence stratigraphic model developed in this study builds a foundation for understanding the occurrence and distribution of distally deposited Triassic source rocks on the North Slope of Alaska.

In addition, sequence stratigraphic analysis of these units expands our knowledge of the geology of Alaska, provides models applicable to paleogeographic reconstructions of the Arctic, and provides insight into the paleogeography and paleoceanography during a crucial period from pre-rifting through the onset of rifting in the Canada Basin (Hubbard et al., 1987; Hulm, 1999).

\section{REGIONAL GEOLOGY}

In northern Alaska, Mississippian through Recent rocks rest unconformably on a suite of dominantly metamorphosed early Paleozoic and Proterozoic sedimentary rocks (fig. 2; Moore et al., 1994). The rocks overlying this unconformity consist of eight megasequences, each coinciding with a major phase of basin evolution (Hubbard et al., 1987). The megasequences were grouped into three plate sequences: the Ellesmerian, Beaufortian, and Brookian (fig. 2; Hubbard et al., 1987). Upper Lower through Upper Triassic units are within the upper Ellesmerian megasequence (fig. 2). Deposition of the Ellesmerian sequence began early in the Carboniferous on a south-facing (present-day coordinates) continental margin and ended in the latest Triassic or early Jurassic. The Beaufortian sequence comprises Jurassic through early Cretaceous rocks overlain by a Lower Cretaceous unconformity (LCu; fig. 2; Moore et al., 1994).

In the northeastern Brooks Range the Lower Ellesmerian megasequence consists of Mississippian nonmarine and shallow marine siliciclastics of the Endicott Group, Mississippian-Pennsylvanian marine carbonates of the Lisburne Group (Alapah and Wahoo 
formations), Permian and Lower Triassic siliciclastic, nonmarine to marine facies of the Sadlerochit Group (Echooka and Ivishak Formations) and the upper Lower to Upper Triassic marine siliciclastics, phosphorites, and carbonates of the Shublik and related formations (fig. 2; Moore et al., 1994). A pre-Upper Permian unconformity separates the Lisburne Group and the Echooka Formation; the latter records Permian transgression with deposition of fluvial conglomerates, that infilled subaerial paleovalleys, grading upward into marine facies
(Crowder, 1990). The overlying Ivishak Formation is a southerly prograding deltaic and fluvial deposit of dominantly quartz arenite, conglomerate, and siltstone lithologies (Jones and Speers, 1976; Crowder, 1990). The Middle Triassic Fire Creek Siltstone makes up the uppermost Ivishak Formation and records the first marine deposition in the northeastern Brooks Range (figs. 2, 3; Crowder, 1990). The Shublik Formation conformably overlies the Fire Creek Siltstone (figs. 2, 3; Detterman et al., 1975).

A.

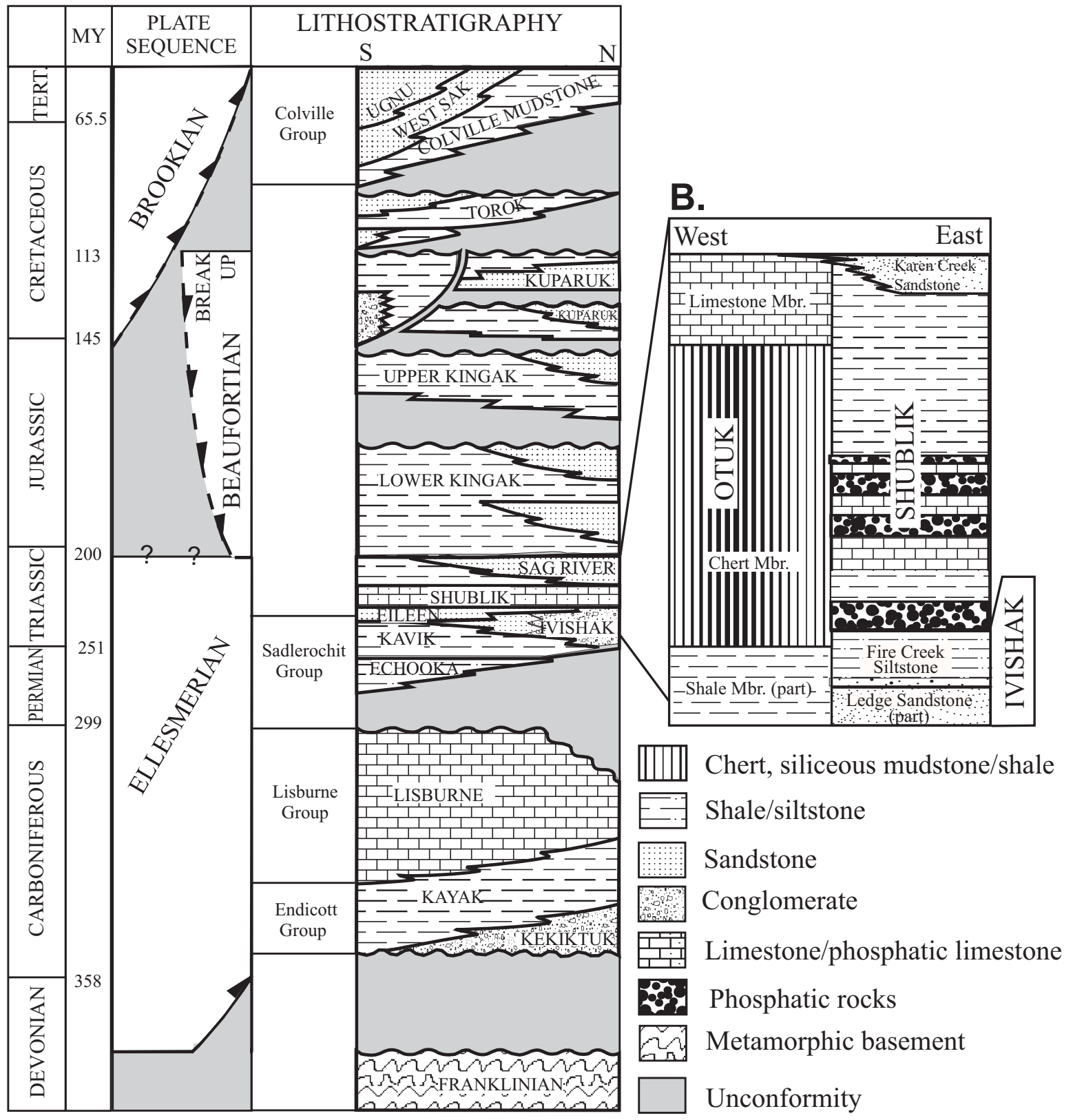

Figure 2. A. Generalized subsurface stratigraphy of northern Alaska (modified from Hubbard et al., 1987). Period boundary ages from Gradstein and Ogg (2004). B. Triassic outcrop stratigraphy of the central and northeastern Brooks Range (modified from Detterman et al., 1975; Mull et al., 1982; Bodnar, 1984; Parrish et al., 2001a, b). 
In the central Brooks Range, the Lower Ellesmerian succession is similar through the upper Lisburne Group but the uppermost Lisburne and overlying units imply deepening possibly due to greater differential subsidence (Whalen et al., 2005). Overlying the Lisburne are shales and siltstones of the Permian Siksikpuk Formation and Lower through Upper Triassic and Lower Jurassic rocks represented by the Otuk Formation (figs. 2, 3; Bodnar, 1984). The Otuk thus contains distal equivalents of the Ivishak and Shublik Formations. The Triassic units examined here include the uppermost Ivishak Formation and overlying Shublik Formation and the laterally equivalent Otuk Formation.

Regionally, the upper Lower through Upper Triassic units across the North Slope display a pronounced thickening and then gradual thinning from north to south, indicating a south-facing continental margin (fig. 1; Molenaar et al., 1986; Moore et al., 1994; Hulm, 1999). The most abrupt variations in thickness occur approximately parallel to the northern coastline of Alaska where deposition was influenced by paleohighs and post-depositional erosion (Jones and Speers, 1976; Hulm, 1999).

The northern Brooks Range consists of a series of thrust-fault-bounded, stacked allochthons, the lowest of which is the Endicott Mountains allochthon (Mull et al., 1982; Moore et al., 1994). Thrusting occurred from the Middle Jurassic through the Early Cretaceous and transport distances are estimated to range from tens to hundreds of kilometers (Mull et al., 1982; Mull et al., 1987; Stone and Wallace, 1987; Kelley and Brosgé, 1995). The northeastern Brooks Range has a different structural configuration, consisting of a series of parautochthons, i.e., thrust-faulted detachment folds (Moore et al., 1994; Wallace and Hanks, 1990). Deformation of the northeastern Brooks Range is reported to be a much later event than thrusting in the central and western Brooks Range, occurring through most of the Cenozoic and continuing to the present (Wallace and Hanks, 1990).

Incipient rifting of Arctic Alaska began during the Jurassic (Moore et al., 1994) or possibly as early as the Late Triassic (Hulm, 1999). In the Early Cretaceous (Hauterivian), Arctic Alaska began to rift away, most likely from the Canadian Arctic Islands, in a counterclockwise rotation about a pole in the Mackenzie Delta (Lawver and Scotese, 1990; Grantz et al., 1994; Mickey et al., 2002). This rotational model is the most widely accepted theory to explain the current configuration of Alaska's North Slope (Tailleur, 1973; Newman et al., 1979; Halgedahl and Jarrard, 1987; Grantz et al., 1994; Mickey et al., 2002). Rifting continued to early Late Cretaceous time (Grantz et al., 1994) and resulted in a change from northerly-derived Ellesmerian sediments to southerly-derived Brookian detritus.

\section{TRIASSIC STRATIGRAPHY \\ SUBSURFACE}

Stratigraphic terminology varies between the subsurface and progressively more distal Brooks Range outcrops. The Eileen Sandstone, Shublik Formation, and Sag River Sandstone (fig. 2) make up the Triassic of the North Slope subsurface. These units are truncated to the north where they onlap the Barrow arch or have been removed through post-depositional erosion along the LCu (Hubbard et al., 1987; Hulm, 1999; Parrish et al., 2001a, b). The Triassic units dip southward in the subsurface, across the North Slope, to the foothills of the Brooks Range where they or their distal equivalents appear as outcrops within thrust sheets (fig. 3).

The top of the Lower to Middle Triassic Ivishak Formation represents a regional erosional unconformity (Crowder, 1990; Robison et al., 1996; Hulm, 1999) and a sequence boundary. The overlying Eileen Sandstone is a fine- to medium-grained, burrowed to laminated marine sandstone (Robison et al., 1996) that grades up into the Shublik Formation. The Shublik Formation is a source rock unit and the subjacent Eileen Sandstone and superjacent Sag River Sandstone are reservoir rock units (Bodnar, 1984; Barnes, 1987; Bird and Molenaar, 1987; Bird, 1994; Kupecz, 1995; Hulm, 1999).

The Shublik Formation is laterally and vertically heterogeneous and is made up of claystones, organicrich shales, bioclastic wackestones and packstones, sandstones, nodular and pebbly phosphorites, and phosphatic and glauconitic sandstones (Detterman, 1970; Tourtelot and Tailleur, 1971; Parrish, 1987; Kupecz, 1995; Hulm, 1999; Parrish et al., 2001a, b; this study). It was subdivided into four lithologically and geophysically distinct zones (D through A) from the base to top (fig. 3) based on well log picks in the Prudhoe Bay Unit Common Database and subsurface core descriptions from the Prudhoe Bay Unit and NPRA (Kupecz, 1995; Hulm, 1999). The contact between the Shublik Formation and the overlying Sag River Sandstone has been described as both conformable (Barnes, 1987; Bird, 1985) and unconformable (Kupecz, 1995). The Sag River Sandstone is a tan, very fine- to fine-grained, bioturbated, argillaceous, glauconitic, quartz sandstone with minor siltstone and local shale (Barnes, 1987)

Triassic rocks, equivalent to those found in the subsurface of the North Slope of Alaska, are present as outcrops in the north-central and northeastern Brooks Range (Mull et al., 1982; Bodnar, 1984, 1989; Parrish et al., 2001a, b). These outcrop equivalents (fig. 4) to the subsurface strata are the focus of this study.

\section{NORTHEASTERN BROOKS RANGE}

From the coastal plain, Triassic units dip and thicken south toward the front of the Brooks Range (Molenaar 


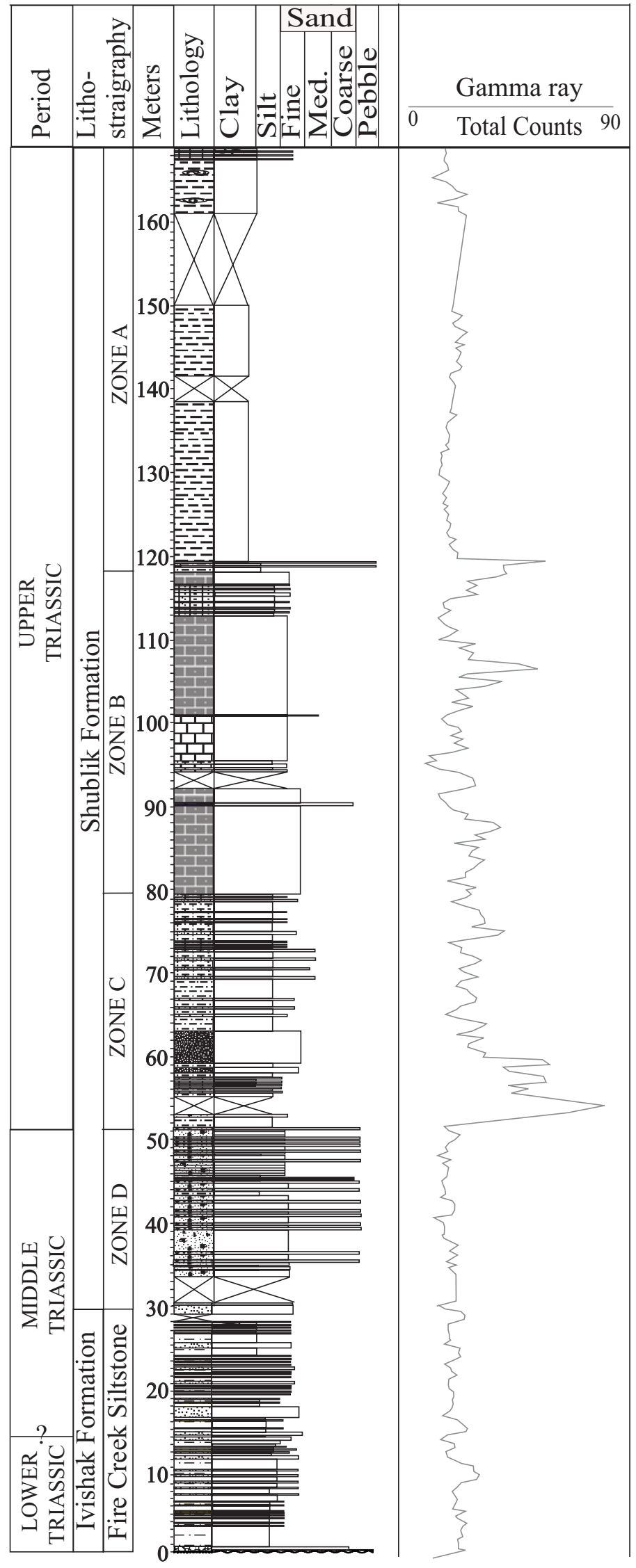

\section{Lithologies}

\begin{tabular}{|c|c|}
\hline & Sandstone \\
\hline & Siltstone \\
\hline & Calcareous siltstone \\
\hline $\begin{array}{l}E=\overline{=}=-7 \\
=\overline{=}=\overline{-}\end{array}$ & Mudstone/shale \\
\hline & $\begin{array}{l}\text { Calcareous mudstone/ } \\
\text { shale }\end{array}$ \\
\hline 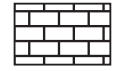 & Limestone \\
\hline $\begin{array}{ll}1 \\
1 \\
1 \\
1\end{array}$ & Phosphatic limestone \\
\hline & Phosphatic sandstone \\
\hline & Sandy phosphorite \\
\hline
\end{tabular}

Figure 3. Stratigraphy and gamma ray response of Lower(?) to Upper Triassic rocks exposed at Fire Creek, northeastern Brooks Range. Illustrated are geologic age, lithostratigraphic units, Shublik Formation zonal subdivisions, thickness in meters, lithology, average grain size, and gamma ray response. Note the high gamma ray response within dominantly phosphatic facies of Shublik Formation zones B and C. 
et al., 1986). Mississippian and younger rocks in the northeastern Brooks Range are part of a parautochthonous succession (fig. 2) similar to that found in the subsurface (Brosgé et al., 1962; Moore et al., 1994). Upper Lower to Upper Triassic rock units located in the northeastern Brooks Range include the Fire Creek Siltstone, the uppermost member of the Ivishak Formation, and the overlying Shublik Formation (figs. 3, 4; Detterman et al., 1975). The Fire Creek Siltstone is interpreted as the distal equivalent of the Eileen Sandstone, based on its stratigraphic position, erosional basal con- tact with the underlying Ledge Sandstone Member, and facies stacking patterns (Detterman et al., 1975; McMillen and Colvin, 1987). The Fire Creek Siltstone is Smithian (Early Triassic) in age and the Shublik Formation ranges in age from Anisian or Ladinian through the Norian stage of the Triassic (Detterman et al., 1975).

The Fire Creek Siltstone rests unconformably on the fluvio-deltaic Ledge Sandstone member of the Ivishak Formation and consists of a thin conglomerate and cyclic bedded mudstones, muddy siltstones, and finegrained, argillaceous sandstones (figs. 3-6; Crowder,

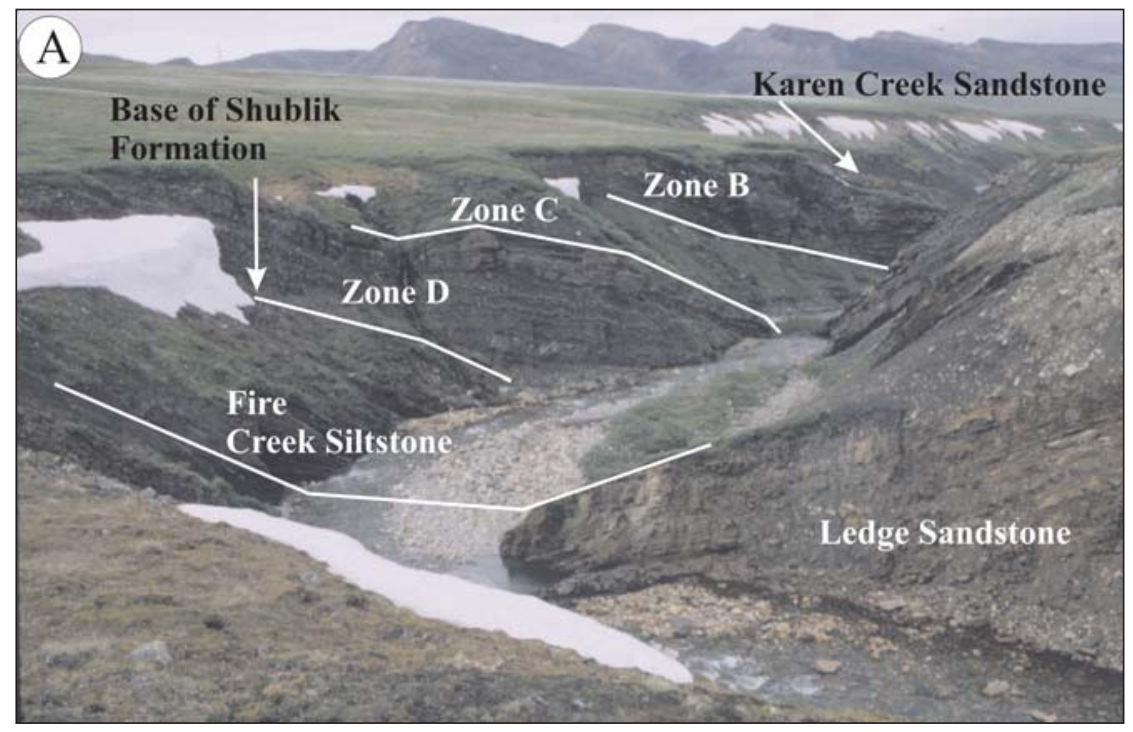

Figure 4. Outcrop photographs of upper Lower-Upper Triassic rocks, northeastern and central Brooks Range.

A. Photograph of the upper Ledge Sandstone and Fire Creek Siltstone members of the Ivishak Formation, the Shublik Formation, and Karen Creek Sandstone in outcrop along Fire Creek, Shublik Mountains. Individual units and zones within the Shublik Formation are illustrated. Note that Shublik Formation zone A is obscured by the topography of the outcrop that makes up upper zone B.

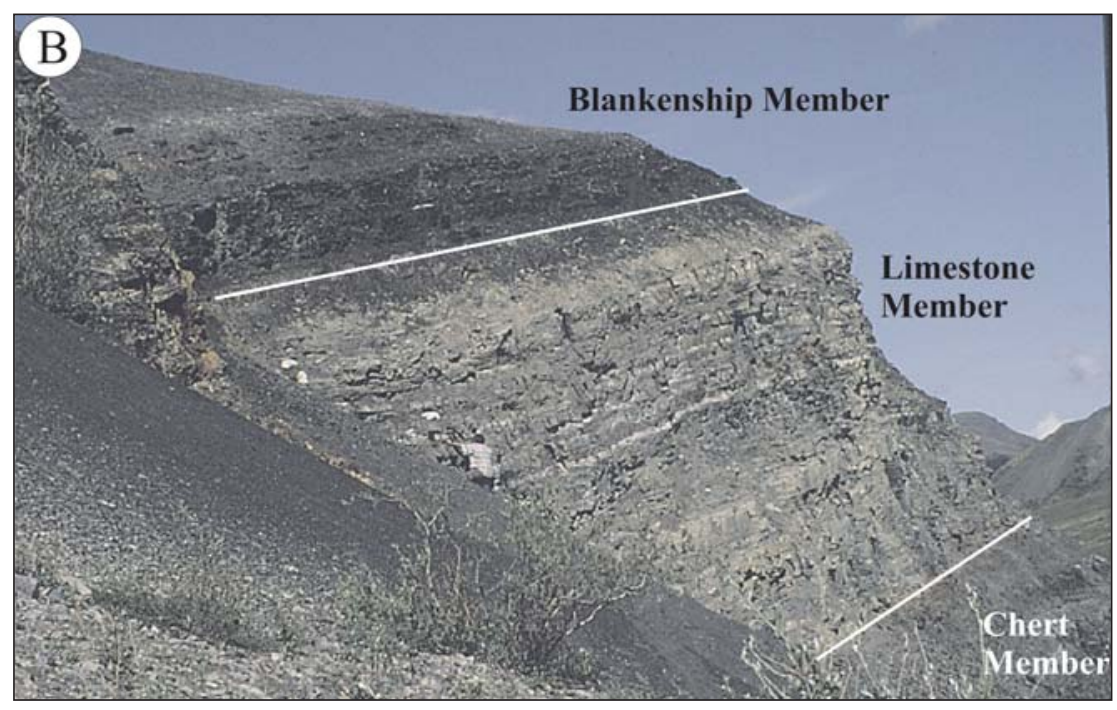

B. Outcrop photograph of the Otuk Formation exposed along the Atigun River. Illustrated are the upper parts of the chert, limestone, and Blankenship members. 
1990). It grades into phosphatic siltstone and fine sandstone of the lower Shublik Formation (fig. 3-6; Detterman et al., 1975; Crowder, 1990). The Karen Creek Sandstone, considered a distal equivalent of the Sag River Sandstone, conformably overlies the Shublik Formation (figs. 3, 4, 6; Detterman et al., 1975) and is massive, burrowed, fossiliferous, and locally phosphatic sandstone.

\section{NORTH-CENTRAL BROOKS RANGE}

The north-central Brooks Range exposes a series of seven stacked, thrust-faulted allochthons (Mull et al., 1982; Moore et al., 1994). Exposures of the Otuk Formation can be found in the northern foothills (fig. 4) within the structurally lowest Endicott Mountains Allochthon (Mull et al., 1982; Bodnar, 1984, 1989). The Otuk Formation contains the shale, chert, limestone, and Blankenship members and consists of mudstones, organic-rich shales, chert, and limestones ranging in age from early Triassic to Jurassic (Bodnar, 1984, 1989). It records deposition prior and subsequent to accumulation of the Fire Creek siltstone and Shublik Formation. The Fire Creek siltstone cannot be distinguished as a separate unit in Otuk Formation exposures. The limestone member of the Otuk Formation is locally capped by a thin sandy interval in outcrops as far west as Atigun
Gorge and a distinctive thin siltstone horizon found as far west as Shainin Lake that appear to be distal lithologic equivalents of the Karen Creek Sandstone (Bodnar, 1989). Our measured stratigraphic section at Tiglukpuk Creek can readily be correlated with that of Bodnar (1984) but we began our section at a thick silty dolostone bed that is located at $20 \mathrm{~m}$ (about $5 \mathrm{~m}$ above the base of the Otuk) in Bodnar's section.

\section{PREVIOUS SEQUENCE STRATIGRAPHIC MODELS}

Previous work on subsurface Triassic rocks of northern Alaska provides sequence stratigraphic models for comparison to the results presented here (Kupecz, 1995; Robison et al., 1996; Hulm, 1999). Kupecz (1995) described the depositional setting, sequence stratigraphy, diagenesis, and reservoir potential of the Shublik Formation in the Prudhoe Bay field. She interpreted the succession to represent two sequences in the Middle and Upper Triassic. A well-log interpretation of the Shublik Formation sequence stratigraphy by Robison et al. (1996) identified only one sequence in the Prudhoe Bay field. The most detailed subsurface sequence stratigraphic interpretation of the Shublik Formation to date, including
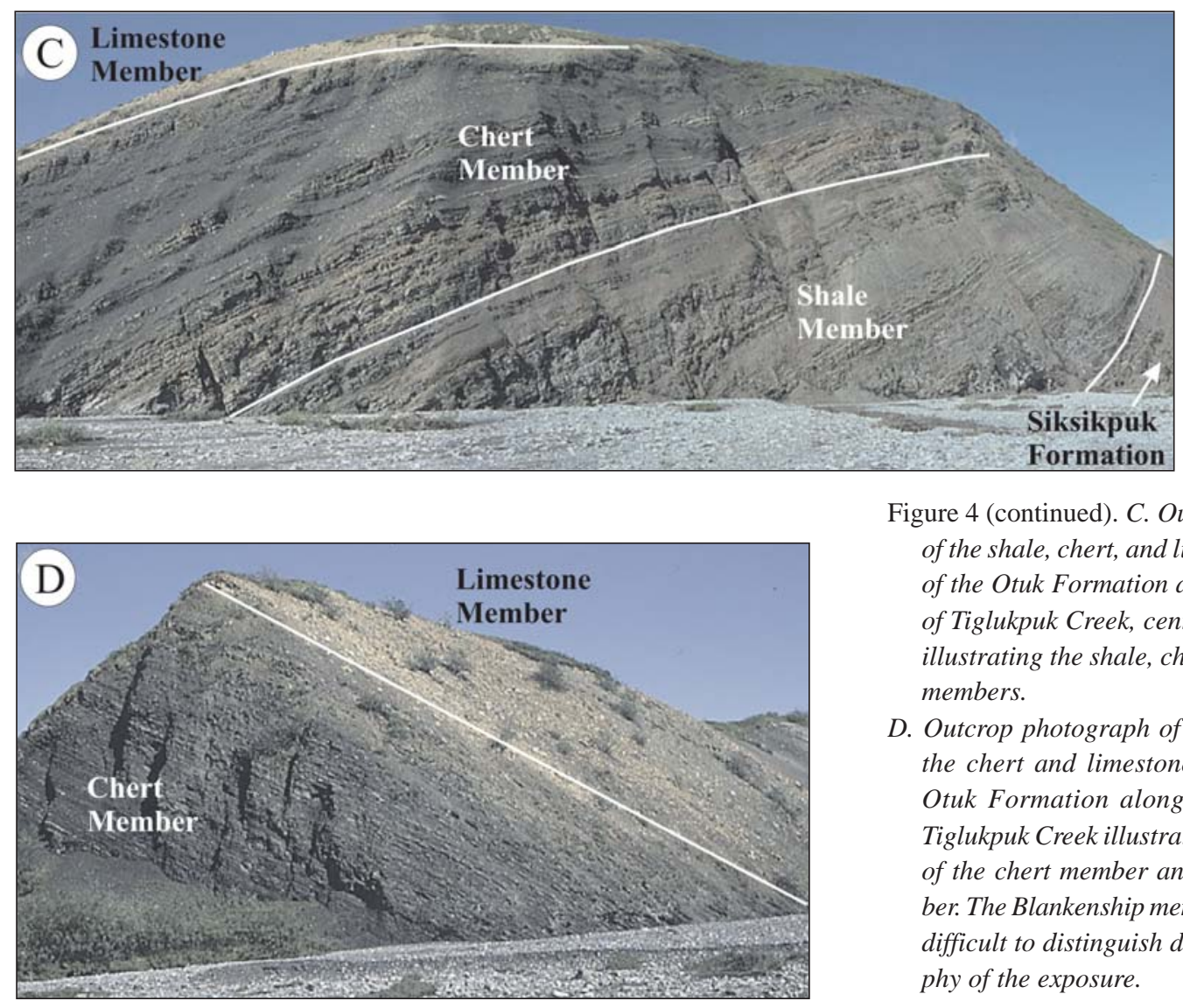

Figure 4 (continued). C. Outcrop photograph of the shale, chert, and limestone members of the Otuk Formation along the east side of Tiglukpuk Creek, central Brooks Range illustrating the shale, chert, and limestone members.

D. Outcrop photograph of the upper part of the chert and limestone members of the Otuk Formation along the west side of Tiglukpuk Creek illustrating the upper part of the chert member and limestone member. The Blankenship member is present but difficult to distinguish due to the topography of the exposure. 
the Eileen Sandstone and the Sag River Sandstone, identifies two complete sequences and a partial third sequence (Hulm, 1999).

\section{OUTCROP LOCATIONS}

The three outcrops that were visited in this study are located on Fire Creek (Ivishak and Shublik Formations), Tiglukpuk Creek (Otuk Formation), and the Atigun River (Otuk Formation) (figs. 1, 4; table 1). The Fire Creek section includes a complete succession of rocks from the base of the Fire Creek Siltstone through the top of the Karen Creek Sandstone (fig. 4). Exposures of the Ivishak and Shublik Formations on Fire Creek are located alternately on the north and south sides of the creek.

The Tiglukpuk Creek section in the north-central Brooks Range includes a nearly complete exposure of the Otuk Formation (fig. 4). The unit crops out on the east and west sides of Tiglukpuk Creek near its confluence with Firestone Creek (fig. 4, table 1). The bulk of the shale and chert members are well exposed on the west side of Tiglukpuk Creek (fig. 4). The upper chert member, limestone member, and lower Blankenship Member are exposed on the east side of the creek (fig. 4) where the upper limestone member forms a south-facing dip slope.

The Atigun River section is located in Atigun Gorge on the north side of the Atigun River approximately 5 $\mathrm{km}$ northeast of the Dalton Highway. A well-exposed section of the upper part of the chert, limestone, and Blankenship members of the Otuk Formation is located in a small bluff just above river level (fig. 4, table 1).

\section{METHODOLOGY}

Previous correlation and sequence stratigraphy of upper Lower through Upper Triassic units provide models of the subsurface geologic architecture (Kupecz, 1995; Hulm, 1999), but there has been little attempt to correlate these units to Brooks Range outcrops. Outcrop data allow Hulm's (1999) and Kupecz’s (1995) subsurface models to be tested and provide data needed for a more regional correlation of the rock units under investigation. Below we use multiple data sets to improve the accuracy of Triassic correlations and ultimately construct a high-resolution surface-to-subsurface sequence stratigraphic model for these rocks. Correlations are based on lithofacies and facies stacking patterns, ichnofabric and biostratigraphic data, gamma ray profiles, and geochemical data, including total organic carbon (TOC), major element, rare earth element (REE), and trace-metal data. All of the data were collected from measured stratigraphic sections in the northern Brooks Range (fig. 1, table 1).

\section{FIELD METHODS}

Each of the three outcrop sections in the Brooks Range (figs. 1, 4) were measured using a 1.5 m Jacob's staff, and samples for lithologic, biostratigraphic, and geochemical analyses were collected at approximately $1 \mathrm{~m}$ spacing. Shallowly covered sections were trenched for fresh samples.

Gamma ray or scintillometer profiles were collected from the outcrops during sampling with a portable gamma ray spectrometer or scintillometer that measures naturally occurring gamma ray emissions from the rocks. At Fire Creek a Scintrex 512 gamma ray spectrometer was used to collect quantitative total gamma ray and $\mathrm{K}$, $\mathrm{U}$, and Th values at half-meter intervals. Scintillometer readings were taken at the Atigun Gorge and Tiglukpuk Creek sections at half-meter intervals. Additional gamma ray spectrometer data were collected from the Tiglukpuk Creek section, which correlated well with the previously collected scintillometer data. The gamma ray and scintillometer profiles are used to aid correlation of outcrop sections with wire line log data from drill holes on the North Slope.

\section{LITHOLOGIC CORRELATION}

Field observation and description of outcrop sections combined with petrographic analysis of rock samples provides the data needed to compare and contrast facies

Table 1. Stratigraphic units present, their attitude, the section, township, range, and map quadrangle for each location.

\begin{tabular}{|c|c|c|c|c|c|}
\hline $\begin{array}{l}\text { Measured } \\
\text { Section }\end{array}$ & Units & Strike/Dip & Section & $\begin{array}{l}\text { Township } \\
\text { \& Range }\end{array}$ & Map \\
\hline $\begin{array}{l}\text { Tiglukpuk } \\
\text { Creek }\end{array}$ & Otuk Fm. & $\mathrm{N} 284^{\circ} / 25^{\circ} \mathrm{SW}$ & $\begin{array}{l}\text { SE } 1 / 4 \text { of SW } 1 / 4 \\
\text { Sec. } 34\end{array}$ & T12S, R1E & $\begin{array}{l}\text { Chandler } \\
\text { Lake B-4 }\end{array}$ \\
\hline Atigun Gorge & Otuk Fm. & $\mathrm{N} 17^{\circ} / 8^{\circ} \mathrm{NW}$ & $\begin{array}{l}\text { NE } 1 / 4 \text { of SW } 1 / 4 \text { of } \\
\text { NE } 1 / 4 \text { Sec. } 23\end{array}$ & T11S, R12E & $\begin{array}{l}\text { Phillip Smith } \\
\text { Mts. B-4 }\end{array}$ \\
\hline Fire Creek & $\begin{array}{l}\text { Fire Creek } \\
\text { Siltstone, } \\
\text { Shublik Fm. }\end{array}$ & $\mathrm{N} 94^{\circ} / 40^{\circ} \mathrm{NE}$ & $\begin{array}{l}\text { NW 1/4, SE 1/4, } \\
\text { \& SW 1/4 Sec. } 11\end{array}$ & T2N, R28E & $\begin{array}{l}\text { Mount Michelson } \\
\text { C-2 }\end{array}$ \\
\hline
\end{tabular}


stacking patterns in different sections. The Shublik and Otuk Formations are heterogeneous (table 2) and partially time correlative units along a proximal to distal transect and display quite different lithologic successions (Detterman et al., 1975; Mull et al., 1982; Bodnar, 1984; Parrish et al., 2001a, b). Lithostratigraphic correlations commonly cut across time boundaries and because of the extreme lithologic heterogeneity are not useful for correlation between the Shublik and Otuk Formations. We will employ facies stacking patterns and abrupt facies changes in the Shublik, Otuk, and related units to help establish temporal correlations in our sequence stratigraphic interpretation.

\section{ICHNOFABRIC INDEX}

The Ichnofabric Index (II) is a semi quantitative method for documenting the extent of bioturbation and preservation of original sedimentary fabrics in the stratigraphic record (Droser and Bottjer, 1986). The II ranges in value from 1 to 5 , with 1 indicating no bioturbation and complete preservation of sedimentary structures and 5 implying that the sediment was nearly to completely homogenized and all primary sedimentary structures were destroyed (fig. 7). Values in between are a measure of the degree to which disruption or preservation of depositional laminae or sedimentary structures has occurred. The presence of ichnofossils was noted during field research and samples were taken where appropriate. Further analysis of hand samples in the laboratory helped in identifying ichnofossils and the II (figs. 6, 7).

\section{BIOSTRATIGRAPHIC CORRELATION}

Biostratigraphy for the outcrop sections includes macrofossils and foraminifera. Biostratigraphy provides

Table 2. Facies summary. Table illustrates facies names and numbers, distinguishing sedimentary features, fauna and biogenic structures, and the interpreted depositional environment.

\section{Facies}

1 Chert pebble conglomerate

2 Medium sandstone

3 Argillaceous fine sandstone

4 Siltstone

5 Mudstone/ shale

6 Wackestone

7 Silty/argillaceous lime and dolostone

8 Phosphatic wacke/packstone

9 Phosphatic siltstone/fine sandstone

10 Pebbly phosphorite

11 Nodular phosphorite

12 Sandy phosphorite

13 Chert

14 Porcelanite
Distinguishing Features

Rounded clasts, clast- to matrix-supported

Well sorted quartz sand

Parallel laminae, wavy parallel and HCS less common

Massive, parallel laminae, platy, tabular cross

bedding, HCS

Platy, papery

Lenses, thin layers

Lenses, thin layers

Cliff forming, phosphatic nodules

Parallel laminae, platy, tabular cross bedding, HCS, phosphatic nodules

Discrete layers, phosphatic pebbles Discrete layers, phosphatic nodules Thin layers, phosphatic sand and nodules

Parallel laminae, 1-10 cm parallel beds Parallel laminae, 1-10 cm parallel beds

\section{Fauna/Biogenic Structures}

None observed
Large bivalves, vertical
burrows
Bioturbation
Cosmorhaphe, Halobia
Monotis/Halobia
Monotis/Halobia,
oysters
Sparse bivalves

Burrows, bioturbation, brachiopods/bivalves/ gastropods and molds Bioturbation, bivalves, shell fragments

Local shell fragments in nodules

Shell fragments, vertical borings

Shell fragments

Burrows/bioturbation

Burrows, bioturbation, Monotis/Halobia
II

Probable Environment

? Inner shelf

3-5 Inner to middle shelf (Swift et al., 1991; Ekdale et al., 1984)

1-3 Inner shelf to Middle (Duke et al., 1991; Cheel, 1991)

1-3 Inner to middle shelf (Duke et al., 1991; Cheel, 1991; Ekdale et al., 1984)

1-3 Middle to outer shelf or basin (Swift et al., 1991)

1-2 Middle to outer shelf (Burchette and Wright, 1992)

1-2 Middle to outer shelf (Burchette and Wright, 1992)

3-5 Middle shelf (Föllmi et al., 1991; Burchette and Wright, 1992)

3-5 Inner to middle shelf (Föllmi et al., 1991; Duke et al., 1991; Cheel, 1991; Ekdale et al., 1984)

? Inner to middle shelf (Föllmi, 1990; Föllmi et al., 1991)

1-2 Inner to middle shelf (Föllmi, 1990; Föllmi et al., 1991)

1-2 Middle shelf (Föllmi, 1990; Föllmi et al., 1991)

2-3 Marginal basin (Jones and Murchey, 1986)

2-3 Marginal basin (Jones and Murchey, 1986) 

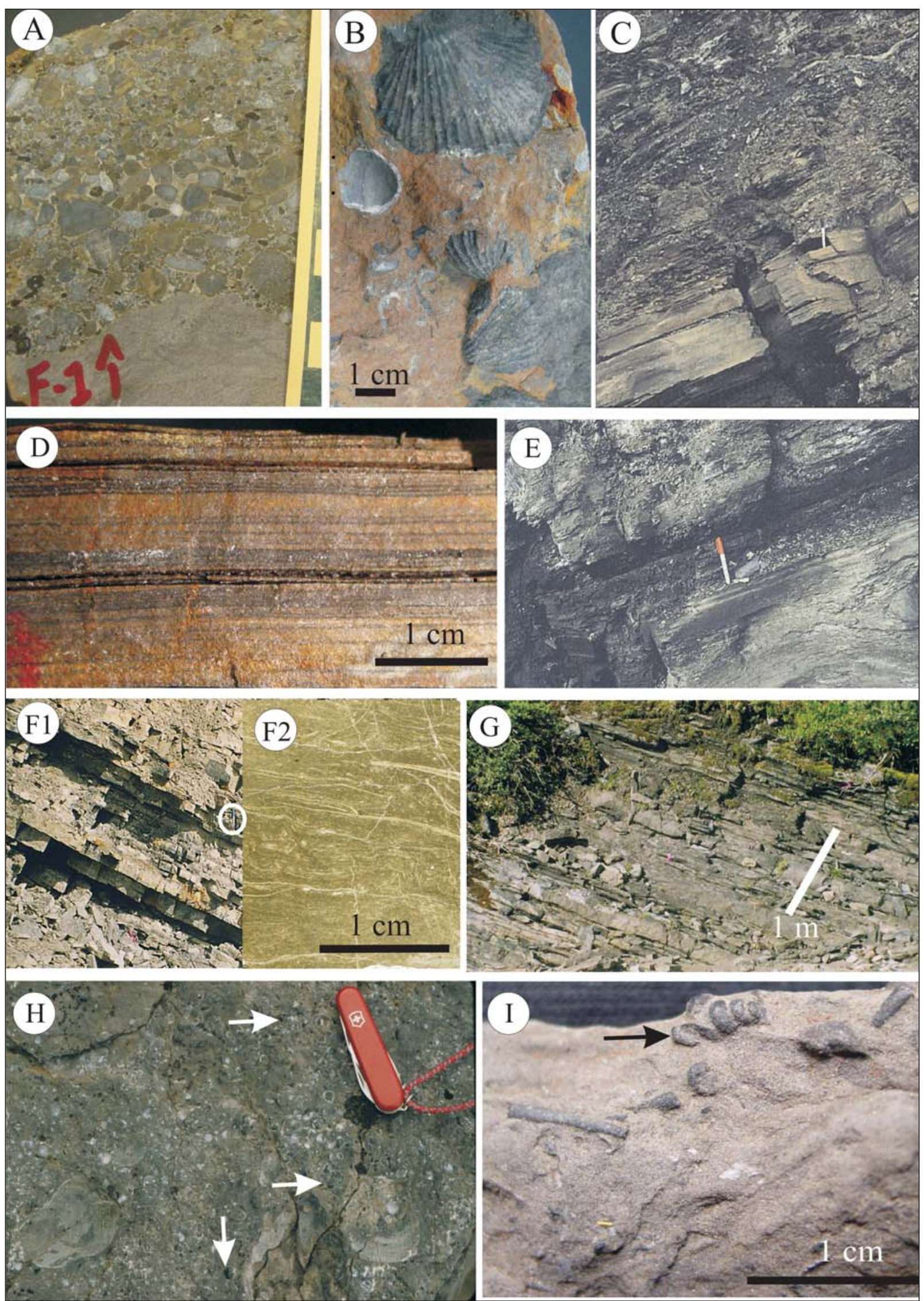


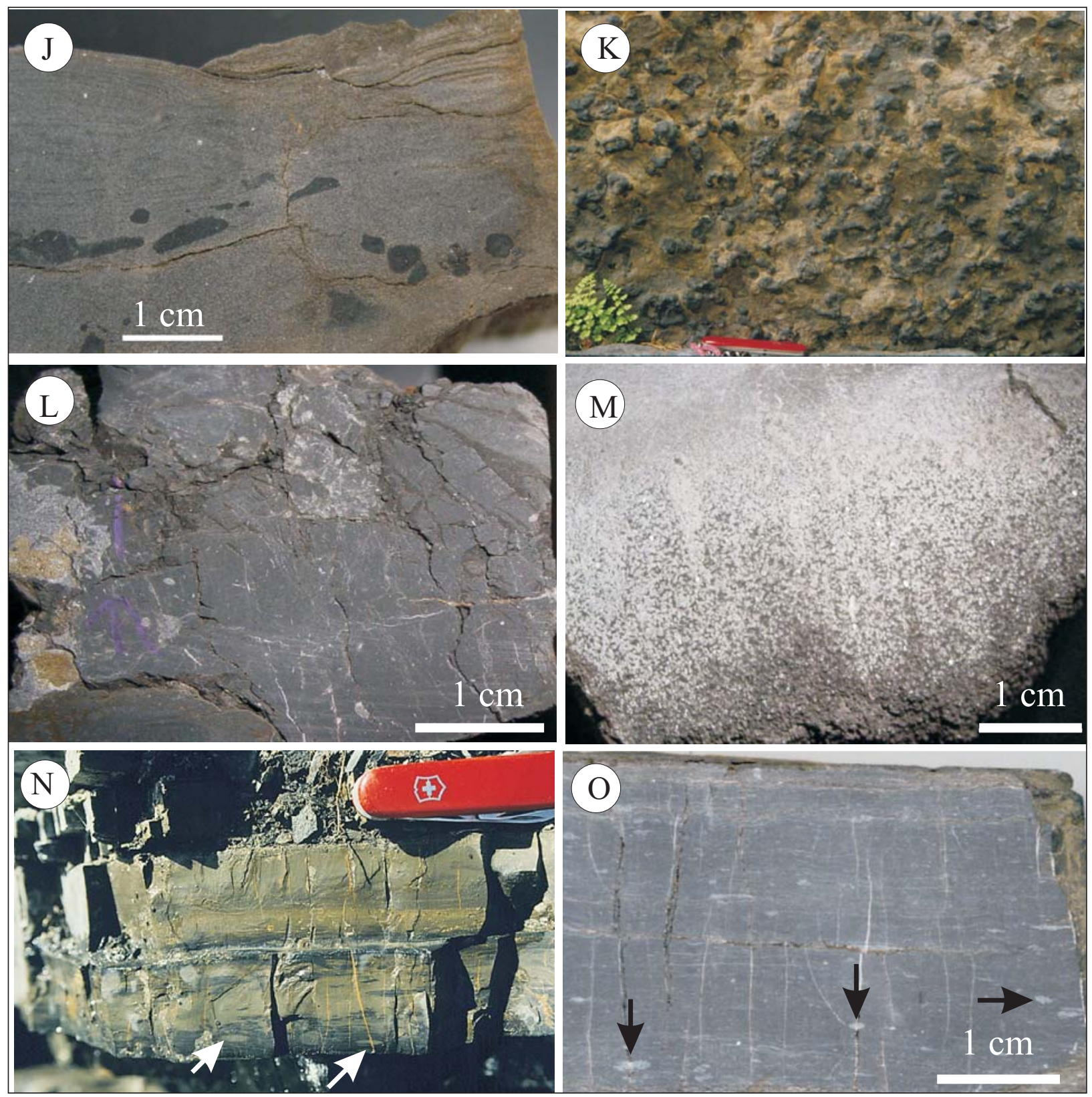

Figure 5. Lithofacies photographs.

A. Facies 1, quartz pebble conglomerate. Photograph of a cut surface of a sample collected at the base of the Fire Creek Siltstone, Ivishak Formation. Note the erosional nature of the basal contact and the grain-supported texture. Scale on right is in centimeters.

B. Facies 2, medium sandstone. Hand specimen photograph of fossiliferous sandstone from the lower Karen Creek Sandstone. Bivalves and other fossils are partially to completely phosphatized or are represented by phosphatized casts.

C. Facies 3 and 4, argillaceous fine sandstone (facies 3) overlain by more friable siltstone (facies 4). Outcrop photograph from the Fire Creek Siltstone. Marker, for scale, is $14 \mathrm{~cm}$ long.

D. Facies 4, siltstone, in Fire Creek Siltstone outcrop. Note the finely laminated texture and thin argillaceous partings.

E. Facies 5, mudstone and shale. Outcrop photograph from the Shublik Formation illustrates the recessive nature of the shale that was trenched for better exposure. Marker for scale.

F. Facies 6, wackestone.

F1. Outcrop photograph of thinly bedded wackestone interbedded with thinner bedded mudstone. Marker (circled) for scale.

F2. Thin section photomicrograph of wackestone with abundant thin-shelled bivalves. Both from the Otuk Formation limestone member. 
Figure 5 (continued).

G. Facies 7, silty argillaceous limestone in the Shublik Formation. Beds are arranged in a series of thin thickeningupward packages.

H. Facies 8, phosphatic wacke/packstone, Shublik Formation. Outcrop photograph illustrating abundant bivalves and other bioclasts, some of which are partially to completely phosphatized (arrows).

I. Facies 8, phosphatic wacke/packstone, Shublik Formation. Hand specimen photograph illustrating phosphatized internal casts of gastropods (arrow) and other bioclasts within a silty, limestone matrix.

J. Facies 9, phosphatic siltstone/fine sandstone. Note the relatively discrete layer of phosphatized burrows, casts, or pebbles within hummocky cross-stratified fine sandstone of the Shublik Formation.

K. Facies 10, pebbly phosphorite, Shublik Formation. Bedding plane photograph illustrating discrete layers with abundant phosphatic pebbles. Knife, for scale, at base of photograph is $9 \mathrm{~cm}$ long.

L. Facies 11, nodular phosphorite. Photograph of cut hand specimen from the Shublik Formation illustrating interlocking phosphatic nodules that include shell fragments and are locally bored.

M. Facies 12, sandy phosphorite. Photograph of cut hand specimen from the Shublik Formation illustrating the sandy texture and white calcitic matrix.

N. Facies 13, chert. Outcrop photograph from the chert member, Otuk Formation. Note the thin, resistant cherty beds with argillaceous partings. Beds are horizontally burrowed (arrows).

O. Facies 14, porcelanite. Photograph of cut hand specimen from the chert member, Otuk Formation. Note the thinly laminated texture and horizontal burrows (arrows).

relative age control between sections, which is essential when correlating laterally variable lithologies and sequences with correlative conformities over great distances. The facies in this study range from shallow marine sandstones and limestones to basinal organic-rich shales and cherts. Foraminiferal analyses were performed by Micropaleo Consultants Inc. (329 Chapalita Drive, Encinitas, California 92024) on samples of siltstone and shale facies. Bivalve biostratigraphy of the Tiglukpuk Creek section provides new age control for the Otuk Formation and greatly improved correlations in this study. Other biostratigraphic control for the Otuk can be found in Mull et al., (1982) and Bodnar (1984). Ages for the Fire Creek section are derived from Detterman et al. (1975) and from foraminifera documented in this study. Bivalve biostratigraphic analysis at Fire Creek would be useful to evaluate the accuracy of correlations between Fire Creek and more distal sections.

\section{PALYNOLOGY}

Palynological analysis provides information about the types of pollen, spores, and organic matter present in rocks or sediment. Samples were processed using standard palynomorph maceration and slide preparation techniques (Traverse, 1988). The objectives of conducting palynological analysis were to determine the origin of the organic matter, identify possible biostratigraphic markers, and document palynomorph affinities to better understand the flora of the region. Any such paleobotanical information might shed light on the nature of the prevailing climate and paleogeography.

\section{INORGANIC GEOCHEMISTRY}

Inorganic geochemical analyses of rock samples include major element, trace metal, and REE analyses. These analyses were preformed at XRAL (1885 Leslie Street, Toronto, ON Canada M3B 2M3). Major element analyses were conducted through $\mathrm{X}$-ray fluorescence (XRF), and trace-metal and rare earth element (REE) analyses were performed using inductively coupled plasma-mass spectrometry (ICP-MS).

The concentrations of certain trace metals vary, depending on the amount of available oxygen within the ocean bottom water or interstitial pore water below the sediment water interface (Breit and Wanty, 1991; Morford and Emerson, 1999; Quinby-Hunt and Wilde, 1996; Wenger and Baker, 1986). Variations in REEs have also been linked to paleoredox conditions (Wright et al., 1987; McLennan, 1989; German and Elderfield, 1990; McLeod and Irving, 1996; Shields and Stille, 2001) and trends in these elements provide additional insight into the depositional and early diagenetic environment.

\section{ORGANIC GEOCHEMISTRY}

Organic geochemical analyses include total organic carbon (TOC), vitrinite reflectance, and Rock-eval. These analyses were conducted at Baseline/DGSI (8701 New Trails Drive, The Woodlands, Texas 77381). TOC is the sum of the total kerogen (insoluble, disseminated organic matter) and bitumen (soluble, disseminated organic matter) in a rock (Waples, 1981) and the concentration is directly related to source-rock quality. The TOC content of a rock also provides some insight into the 
amount of available oxygen within the marine bottom water, because organic carbon is readily oxidized. Rockeval is a method used to determine the types of kerogen and the quality of the organic matter that relate to the petroleum-generative potential of a source rock (Peters, 1986); vitrinite reflectance is a method of determining the thermal maturity of a rock (Waples, 1981).

\section{FACIES DESCRIPTIONS AND FORMATION SUBDIVISIONS}

The Triassic units described here are heterogeneous (table 2) and it was necessary to use a variety of different classification schemes to characterize all the different facies. The following are descriptions of facies included within the Otuk Formation, the Fire Creek Siltstone, and the Shublik Formation. Dominantly siliciclastic rocks are categorized based on the scheme of Pettijohn (1975). For carbonate-rich facies, we use the Dunham (1962) and Embry and Klovan (1972) classification schemes. Many of the facies, especially in the Shublik Formation, contain phosphatic components. These include phosphatic nodules and cements and sedimentary and fossil material replaced by carbonate fluorapatite. Such facies are categorized using Föllmi et al.'s (1991) phosphatic rock classification. Cherty facies of the Otuk Formation are classified according to the scheme of Jones and Murchey (1986). Parrish (1987) and Parrish et al. (2001a) broke the Shublik Formation into four lithofacies including non-glauconitic sandstone, glauconitic, phosphatic, and organic-rich facies. Our facies analysis builds upon this previous work and we define 14 different lithofacies of the Shublik and Otuk Formations, Fire Creek Siltstone, and Karen Creek Sandstone based on lithology, sedimentary and diagenetic features, and biota.

\section{FACIES DESCRIPTIONS}

\section{FACIES 1 CHERT PEBBLE CONGLOMERATE}

The conglomerate facies is up to $10 \mathrm{~cm}$ thick and occurs only at the base of the Fire Creek Siltstone. It is clast supported at the base and grades upward to matrixsupported conglomerate (fig. 5A). Clasts include subangular to well-rounded chert and sandstone lithic pebbles, medium- to coarse-grained quartz sand and minor amounts of mud. Most pebbles have a pyritic coating, giving the conglomerate an orange-weathering appearance. The conglomerate facies is crudely graded but lacks other sedimentary structures, fossils, and trace fossils and overlies an erosionally truncated surface with several centimeters of relief.

\section{FACIES 2 MEDIUM SANDSTONE}

The medium sandstone facies is limited to the Karen Creek Sandstone (up to $5.5 \mathrm{~m}$ thick) and includes fossil- iferous, burrowed, quartz-dominated sandstones (fig. 5B) that can be classified as quartz to sublitharenites, some of which are phosphatic. The facies is tan to orange-tan weathering, well indurated, cemented with phosphatic minerals, and is composed of subangular to subrounded grains of well-sorted, fine to medium quartz sand and bivalve bioclasts with little or no matrix. Within the lower Karen Creek there are abundant, large, unidentified bivalves that are replaced by phosphate or contain internal phosphatic molds (fig. 5B) with calcite shell material preserved in larger, thick-shelled specimens. The center of the unit contains disseminated phosphate nodules several centimeters in diameter. The upper Karen Creek is free of phosphate and contains pyritized, vertical burrows (fig. 6D). The medium sandstone facies is underlain by a thick succession of shale with several limestone lenses just below the transition into sandstone.

\section{FACIES 3 ARGILLACEOUS FINE SANDSTONE}

The argillaceous fine sandstone facies is found throughout the Fire Creek Siltstone and is grain supported and composed of subrounded to rounded, fine- to medium-grained quartz sand with rare muscovite grains, a silt and minor clay matrix, and local calcite cement (fig. 5C). This facies weathers gray-brown or rusty orange-brown, is dark gray to black on a fresh surface (fig. 5C) and can be classified as a quartz arenite to wacke. This facies is parallel laminated to thin bedded (centimeters to decimeters) with local wavy laminae, hummocky cross stratification (HCS, fig. 6A), and soft sediment deformation including folds and ball and pillow structures (fig. 6B). Beds of this facies are locally burrowed and bioturbated. The argillaceous fine sandstone facies is also found locally as thin lenses within siltstone facies.

\section{FACIES 4 SILTSTONE}

The siltstone facies occurs within the Fire Creek Siltstone, Shublik Formation zone C and locally in zones A and $\mathrm{B}$, the Otuk Formation shale member, and locally within the Otuk Formation chert member. The facies is dark gray, locally calcareous or cherty and commonly grades into the argillaceous fine sandstone sand or silty/ argillaceous limestone or dolostone facies. The facies displays a variety of bedding types and sedimentary structures including; massive, parallel laminated (fig. 5D), platy, small-scale tabular cross-bedded, and HCS (fig. 6A). Calcareous siltstone is most commonly interbedded with silty limestones. Cherty siltstone generally occurs in association with Otuk Formation chert facies and contains microcrystalline quartz or spherulitic chalcedony and locally dark gray to black, oblong to ovate chert nodules ranging from 1 to $5 \mathrm{~cm}$ in diameter. There are several examples of the trace fossil Cosmorhaphe within siltstone facies at Fire Creek 
(fig. 6C). Crowder (1990) also noted the occurrence of Diplocraterion and Arenicolites traces within the Fire Creek Siltstone.

\section{FACIES 5 MUDSTONE/SHALE}

The mudstone/shale facies occurs mainly in Shublik Formation zone A. While the lower portion of the Otuk Formation is designated the shale member (Mull et al., 1982) and probably does contain some true shale we found that most shale member facies were silty and fall into facies 4 . The mudstone/shale facies is light gray to black and fissile, platy, or papery or it is siliceous with interbedded dark gray and green cherty lithologies (fig. 5E). The facies commonly contains a minor amount of disseminated pyrite and locally these form orangeweathering patches ranging from 5 to $25 \mathrm{~cm}$ in diameter. Several thin $(<15 \mathrm{~cm})$ brown clay layers occur interbedded with the light gray mudstone. No sedimentary or biological structures were observed in outcrop: however, the uppermost portion of this package contains impressions of well-preserved, black phosphatized monotid clams (fig. 6G).

\section{FACIES 6 WACKE/PACKSTONE}

The wacke/packstone facies occurs as thin to medium beds within Shublik Formation zones C, B and A, and in the Otuk Formation chert and limestone members. The facies is light to dark gray on a fresh surface and weathers light gray to tan and beds are $5-50 \mathrm{~cm}$ thick (fig. 5F1). Wackestone and packstone textures occur interbedded and as burrow-fills within one another. Most of the bioclasts observed in this facies were bivalves and locally they form coquinoid accumulations of halobids or monotids and oysters (figs. 5F2, 8-11). The wacke/packstone facies is associated with the siltstone, silty/argillaceous limestone or dolostone, mudstone and shale, chert, porcelanite, and phosphatic wacke/ packstone facies.

\section{FACIES 7 SILTY/ARGILLACEOUS LIMESTONE OR DOLOSTONE}

The silty/argillaceous limestone or dolostone facies is found in the shale, chert, and limestone members of the Otuk Formation and as part of zones C, B, and A of the Shublik Formation. It ranges in color from light gray to black when fresh, weathers dark gray, and is commonly interbedded with siltstone, mudstone/shale, wacke/packstone, or phosphatic wacke/packstone (fig. 5G) as thin elongate lenses or tabular beds 5-50 cm thick. Lithologically the facies is lime mudstone or locally wackestone. Bioclasts are sparse in this facies but local accumulations of the bivalve Gryphea sp. and rare brachiopods were observed at Atigun Gorge and rare bioclasts were observed in thin sections from Tiglukpuk Creek. When associated with phosphatic facies, silty limestones usually have a phosphate-cemented lime mud matrix.

\section{FACIES 8 PHOSPHATIC WACKE/PACKSTONE}

The phosphatic wacke/packstone facies is confined to Shublik Formation zones C and B. It is dark gray in color on both weathered and fresh surfaces and is generally massive, forming cliff faces. It is associated with siltstone, silty/argillaceous limestone, and wacke/ packstone facies. Fauna in this facies includes brachiopods, bivalves, gastropods, ostracods, crinoids, and foraminifera locally concentrated in coquinas (fig. 5H, I, 7F). Phosphate occurs as elongate to irregular nodules that range in size from a few millimeters to several centimeters and as internal molds of gastropods, brachiopods, and bivalves, burrow fills, and partial-to-complete replacement of bioclasts or matrix (fig. 5H, I). This facies commonly contains minor amounts of pyrite that locally replaces shell material.

\section{FACIES 9 PHOSPHATIC SILTSTONE AND FINE SANDSTONE}

The phosphatic siltstone and fine sandstone facies is restricted to Shublik Formation zone D. It consists of subrounded to rounded very fine quartz and local glauconitic sand or silt-size grains in a black phosphatic matrix (fig. 5J). Phosphate nodules, scattered throughout the matrix, range from a few millimeters to several centimeters in diameter, and are rounded to elongate or irregular in shape. Beds are commonly separated by pebbly phosphorites. The phosphatic siltstone and fine

Figure 6 (right). Sedimentary structures, trace fossils, and megafossils from Triassic rocks of northern Alaska.

A. Hummocky cross-stratification, Fire Creek Siltstone, Ivishak Formation. Knife, for scale, is $14 \mathrm{~cm}$ long.

B. Ball and pillow soft sediment deformation load structures, Fire Creek Siltstone, Ivishak Formation. Knife for scale.

C. Trace fossil Cosmorhaphe, Fire Creek Siltstone, Ivishak Formation.

D. Vertical Skolithos-like burrows, Karen Creek Sandstone.

E. Horizontal to subhorizontal burrows, Limestone member, Otuk Formation. Lens cap, for scale, is $6 \mathrm{~cm}$ in diameter.

F. Abundant horizontal to subhorizontal burrows, Limestone member, Otuk Formation.

G. Phosphatized Monotis ochotica, Shublik Formation.

H. Phosphatized bivalve, Shublik Formation.

I. Impression of a halobid bivalve, Shublik Formation. Marker for scale. 

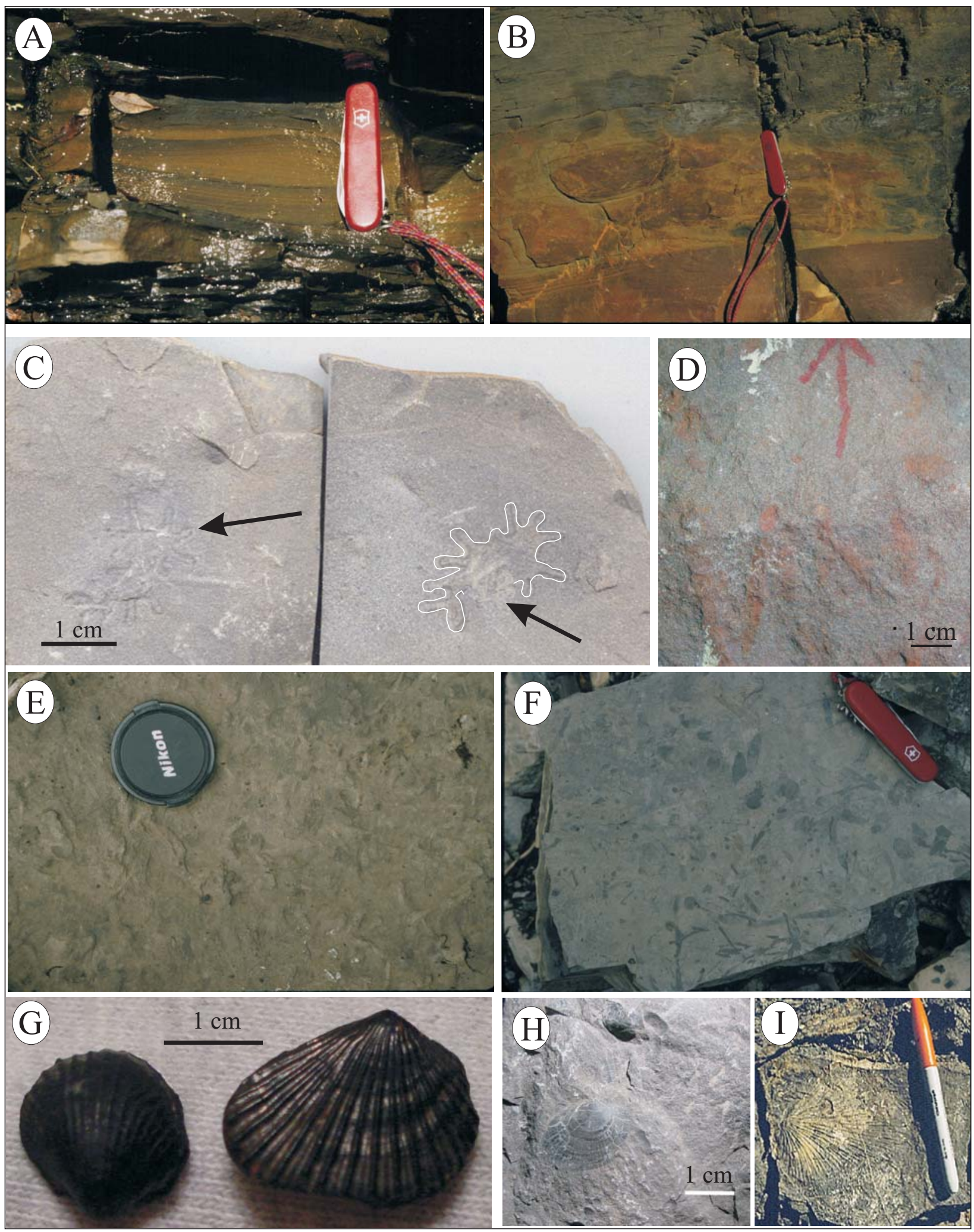


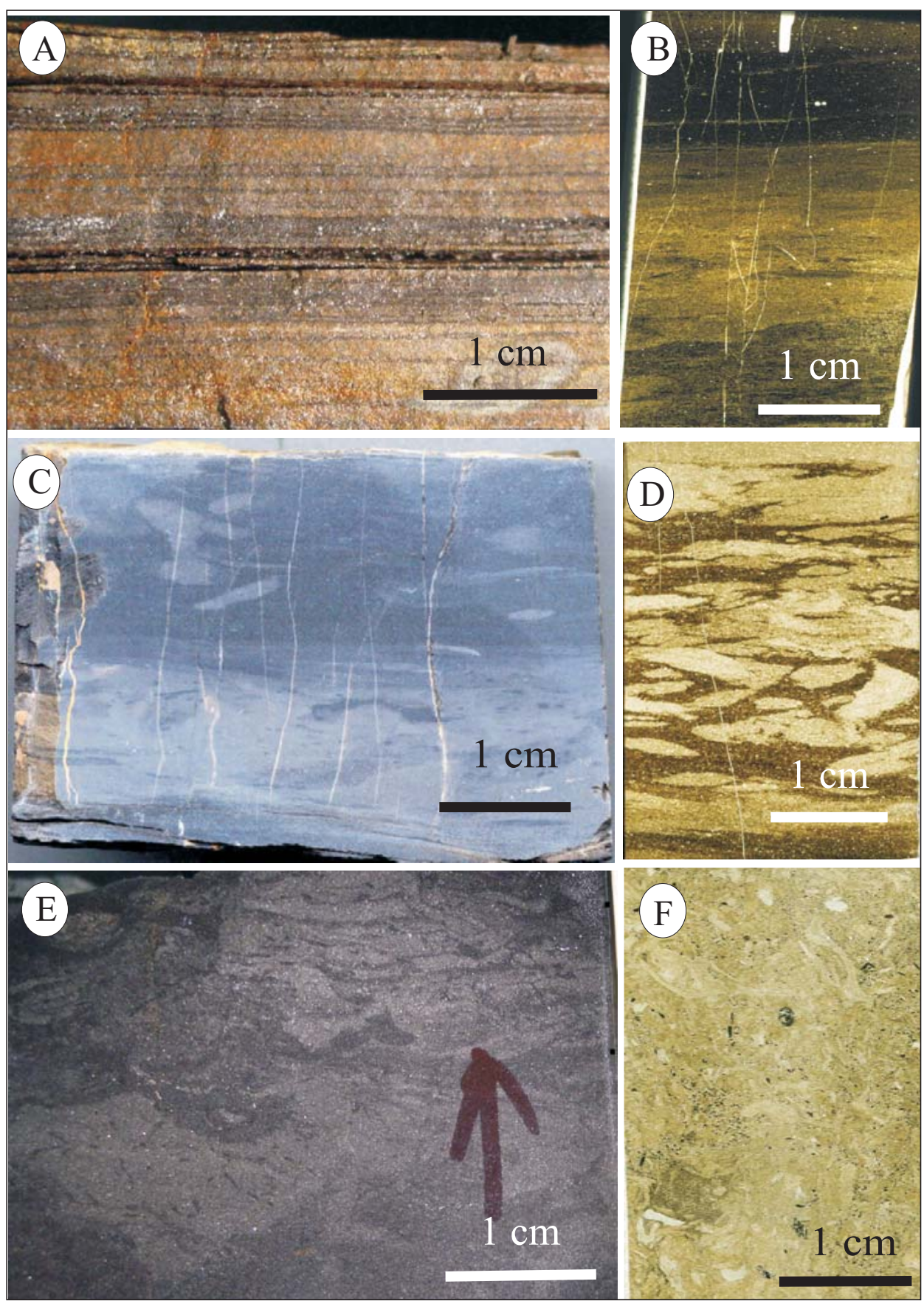

Figure 7. Ichnofabric of the Shublik and Otuk Formations illustrating varying degrees of bioturbation of different ichnofabric indices (II).

A. II-1, sedimentary laminations completely preserved, cut hand specimen, siltstone facies.

B. II-2, minor disruption of bedding by local subhorizontal burrows, thin section photomicrograph, porcelanite facies.

C. II-3, moderate disruption of primary bedding and some cross-cutting burrows, cut hand specimen, wackestone facies.

D. II-4, most primary bedding destroyed, many cross-cutting burrows, thin section photomicrograph, silty argillaceous limestone facies.

E. II-5, most primary bedding destroyed, many burrows cross-cut or obliterated by later bioturbation, cut hand specimen, phosphatic siltstone-fine sandstone facies.

F. II-5, complete homogenization of sediment, thin section photomicrograph, phosphatic wacke/ packstone facies. 
sandstone facies is locally burrowed and commonly homogenized by bioturbation (II=5, fig. 7E). Burrows are up to $0.5 \mathrm{~cm}$ in diameter, oriented horizontal to subhorizontal and filled with phosphatic minerals.

\section{FACIES 10 PEBBLY PHOSPHORITE}

Pebbly phosphorites are concentrated in discrete layers within the phosphatic siltstone and fine sandstone facies (fig. 5K). Beds are usually less than a half meter thick and grade upward from grain to matrix supported. The phosphate pebbles are rounded to subrounded grains, ranging in size from one to a few centimeters. Some pebbles represent internal molds of bivalves, gastropods, brachiopods, or other fossils. The matrix is composed of rare fine quartz sand or silt and the facies commonly contains patchy phosphatic cement.

\section{FACIES 11 NODULAR PHOSPHORITE}

The nodular phosphorite facies is represented by two thin layers at the top of Shublik Formation zone D at Fire Creek. Dark gray to black phosphatic nodules range in size from 3 to $6 \mathrm{~cm}$ and contain pyritized shells and shell fragments and small vertical borings filled with calcite (fig. 5L). Some nodules represent internal molds of bivalves, gastropods, brachiopods, or other fossils. The sediment surrounding the nodule layers is dark gray, rusty orange-weathering siltstone with abundant pyrite nodules.

\section{FACIES 12 SANDY PHOSPHORITE}

The sandy phosphorite facies is documented only in the lower portion of Shublik Formation zone C. It is grain supported, with rounded to well-rounded, very fine to medium sand-sized black phosphatic and quartz grains in a sparry calcite matrix (fig. 5M). This unit weathers a dark bluish gray and is dark gray on a fresh surface. Beds are up to $20 \mathrm{~cm}$ thick, have wavy bedding surfaces and are locally interbedded with siltstone. Phosphatic grains include ooids (most with quartz sand nuclei), peloids, and intraclasts. The facies contains bivalve shell fragments, rare echinoderm fragments, and scattered phosphate nodules about 1 to 2 centimeters in diameter. Most shell fragments are relatively unaltered but some are recrystallized or replaced with pyrite.

\section{FACIES 13 CHERT}

The chert facies is largely restricted to the Otuk Formation chert member although nodules of chert are found within the shale, chert, and limestone members. The chert facies is composed dominantly of microcrystalline quartz or chalcedony with less than 25 percent siliciclastic impurities (Jones and Murchey, 1986). This facies ranges in color from gray to light brown on a fresh surface (fig. 5N). Bedding thickness ranges from 1 to 10 cm; beds are usually parallel laminated with burrows (fig. $5 \mathrm{~N}$ ), and are commonly intercalated with millimeter-scale beds of mudstone or shale. Chert is also associated with siltstone and porcelanite. The chert facies may include minor amounts of nodular or disseminated pyrite. Identifiable siliceous biogenic remains include rare radiolarians and sponge spicules.

\section{FACIES 14 PORCELANITE}

The porcelanite facies is found mainly within the Otuk Formation chert member but also in the limestone member. It is dominantly siliceous with $25-50$ percent siliciclastic impurities (Jones and Murchey, 1986). Most of the silica is recrystallized to microcrystalline quartz although some is chalcedonic. This facies ranges in color from medium gray to dark gray on a fresh surface and from tan to dark gray when weathered (figs. 5O, 7B). Identifiable siliceous biogenic remains include radiolarians and sponge spicules. This facies also contains recrystallized halobid or monotid or other bivalves or casts of their shells. The number of shells ranges from a few per hand sample to packed coquinas of layered flat shells that create parting surfaces and a wavy-bedded appearance. This facies is usually parallel laminated and commonly associated with chert and interbedded with centimeter- to decimeter-scale beds of siltstone or less commonly mudstone and shale. Porcelanite commonly contains burrows that are easily recognizable by their well-defined oval or elongate shapes that weather a different color than the rest of the rock (fig. 50). The porcelanite facies commonly includes disseminated pyrite or centimeter-scale pyrite nodules.

\section{SUBDIVISIONS OF THE SHUBLIK AND OTUK FORMATIONS}

In the Prudhoe Bay subsurface, the Shublik Formation was divided into five members by Jones and Speers (1976) based on lithofacies and geophysical logs. The lowermost member of Jones and Speers was later broken out as the Eileen Sandstone, a lithologic equivalent of the Fire Creek Siltstone (Detterman et al., 1975). The upper four members of Jones and Speers were later described as four zones in the Prudhoe Bay Common Unit database (e.g., Kupecz, 1995). Hulm (1999) extended the zonal subdivision over a much broader area including the NPRA. The subsurface zonal subdivision is applied to the outcrop at Fire Creek but there are some differences in the lithostratigraphy that are summarized below (figs. 8-11). The boundaries for the zones are recognizable and commonly occur at or near divisions between systems tracts (discussed below).

\section{SHUBLIK FORMATION ZONAL SUBDIVISIONS}

Detterman et al. (1975) informally subdivided the Shublik Formation into a siltstone, limestone and dolostone, and clay shale members. In the subsurface of 
northern Alaska the Shublik Formation is subdivided into four zones designated D through A (figs. 8-11) and this subdivision can also be recognized in outcrop. Zone D represents the lowermost Shublik Formation and is up to $14 \mathrm{~m}$ thick but commonly is not present at all (figs. 8, 11; Kupecz, 1995; Hulm, 1999). It is a massive, fine- to medium-grained, moderately- to well-sorted phosphatic sandstone, calcareous shale, and bioclastic limestone with a paucity of fossils (Kupecz, 1995; Hulm, 1999). At Fire Creek, zone D is $18 \mathrm{~m}$ thick and consists mainly of phosphatic sandstone and siltstone and pebbly phosphorites with locally interbedded siltstone. In the subsurface zone $\mathrm{C}$ is from 0 to $22 \mathrm{~m}$ thick and consists of a thin layer of phosphatic sand overlain successively by sandy shale, black shale, thinly interlaminated black shale, siltstone, thin calcareous sandstone, dark gray lime packstone and grainstone, and light gray shaly limestones (figs. 9, 11; Kupecz, 1995; Hulm, 1999). In the Fire Creek exposure, zone $\mathrm{C}$ is $27 \mathrm{~m}$ thick and dominated by siltstones but contains sandy phosphorite in the lower part and interbedded wacke/packstone and silty lime mud/ wackestone. In the subsurface, zone B ranges in thickness from 0 to $17.5 \mathrm{~m}$ and consists of pelletal and nodular phosphorites, phosphatic carbonates with interlaminated shale, phosphatic shales, phosphatic siltstones, and graded packstone and grainstone that are locally oolitic s (figs. 9, 11; Kupecz, 1995; Hulm, 1999). At Fire Creek, zone B is 38.5 m thick and composed dominantly of phosphatic wacke/packstone with intervals of wacke/ packstone, silty/argillaceous limestone, and siltstone. In the subsurface, zone A is $0-27 \mathrm{~m}$ thick (figs. 10, 11; Kupecz, 1995). The contact between zones A and B is sharp, with basal black shales grading vertically into dark gray interlaminated shale and carbonate grainstone and packstone or siltstones (Kupecz, 1995; Hulm, 1999). The interlaminated shales and carbonates grade upward into light gray, bioturbated, shaly bioclastic limey grainstone and packstone (Kupecz, 1995; Hulm, 1999). In the Fire Creek section, zone A is $50 \mathrm{~m}$ thick. The base is sharp and overlain by two distinctive beds of nodular phosphorite. The overlying section is dominated by mudstone and shale with nodules and thin interbeds of wacke/ packstone near the top of the zone.

\section{SUBDIVISIONS OF THE OTUK FORMATION}

The Otuk Formation has previously been divided into five members including the informally named shale, chert, and limestone members (Mull et al., 1982), and the formally designated Karen Creek and Blankenship Members (figs. 8-11; Bodnar, 1989). The following is a summary of the Otuk Formation lithofacies descriptions from Bodnar (1984).
The shale member consists of black pyritic shale interbedded with gray-weathering silty or argillaceous dolostone and limestone beds and nodules with local light-green dolomitic siltstone interbeds and siliceous phosphate nodules and concretions (figs. 8, 11). The chert member consists of rhythmically interbedded chert and black shale with minor thin, black limestone beds (figs. 8-11). Local occurrences of very thin coquinoid limestone laminae were noted throughout the chert member, but are most common in the upper portion. The limestone member consists of rhythmically interbedded, tan-weathering, fine-grained limestone and black shale, with local occurrences of thin coquinoid layers (figs. 10, 11). The limestone member is locally capped by a black, orange-tan weathering, calcareous cemented siltstone or fine-grained sandstone that lacks sedimentary structures (figs. 10, 11). The Blankenship Member is dominantly black, organic-rich shale, but the top 0.2 to $0.5 \mathrm{~m}$ is gray and yellow mottled clay. Additional detailed descriptions of Otuk Formation exposures specific to Tiglukpuk Creek and Atigun Gorge can be found in Mull et al. (1982) and Bodnar (1984; 1989).

\section{FACIES ASSOCIATIONS AND INTERPRETATIONS}

The facies described in this study cover a wide variety of lithologies, grain sizes, and textures. The conformable vertical stacking of facies implies lateral facies relationships and the association of adjacent facies provides information about depositional environments. Key features of individual facies such as sedimentary or biogenic structures, the fauna, and ichnofabric index also provide criteria for interpreting the depositional setting (table 2). The 14 facies defined above occur in nine associations that we interpret below in terms of depositional environments. These facies associations form the building blocks for our sequence stratigraphic model and interpretation of sea-level history. Facies associations are based on stratal stacking patterns that indicate retrogradation, progradation, or aggradation and imply transgression, regression, or stillstand of ancient shorelines, respectively. Facies stacked into genetic units that are bounded above and below by marine flooding surfaces are considered parasequences and similar stacked sedimentary cycles are referred to as parasequence sets (Van Wagoner et al., 1988). Due to variations in lithostratigraphy, facies associations in the more proximal Fire Creek section differ significantly from those at the more distal Atigun Gorge and Tiglukpuk Creek localities. Six proximal and three distal facies associations are described below. 


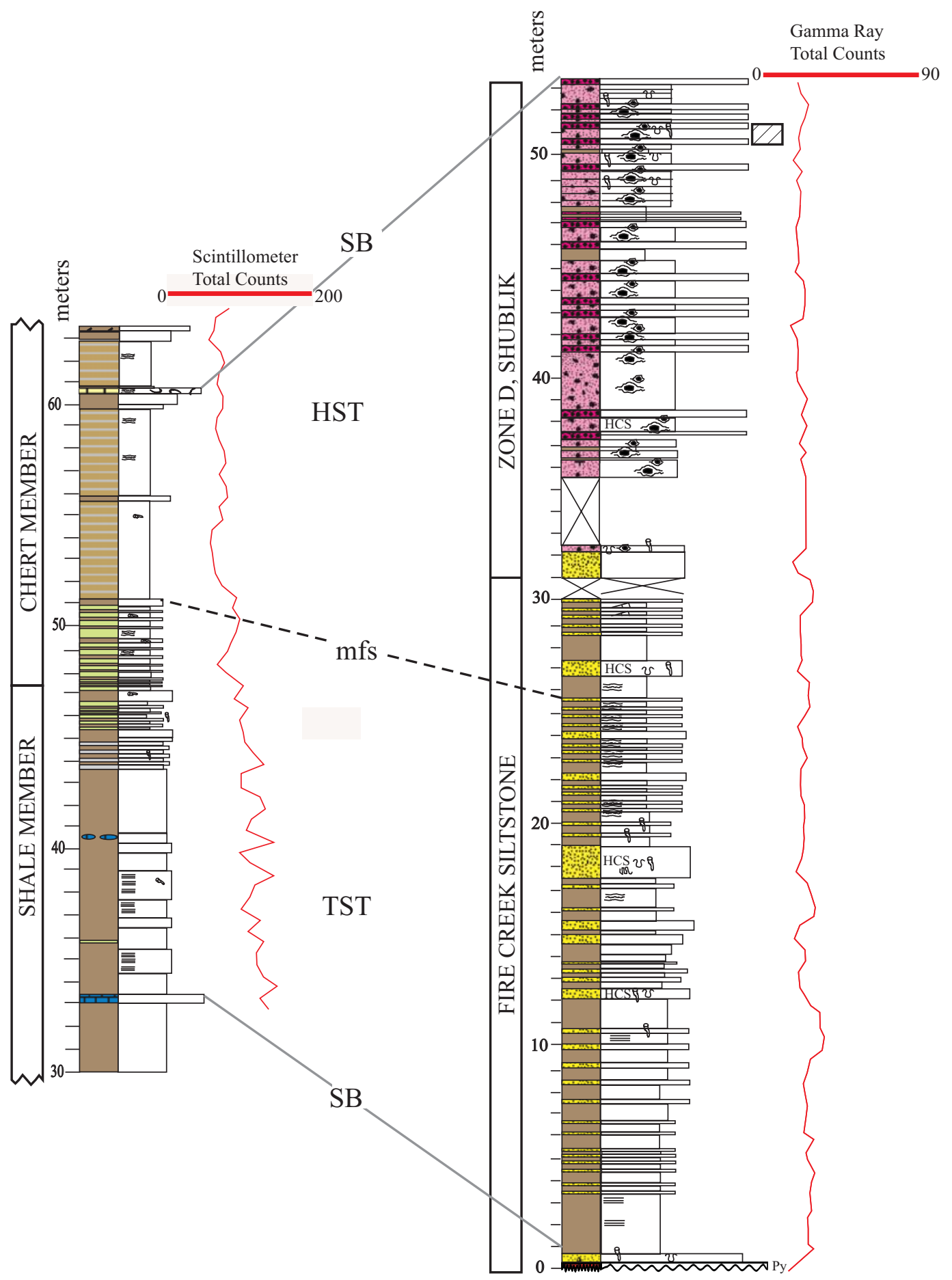

Figure 8. Correlation of sequence one between the lower Otuk Formation at Tiglukpuk Creek (left) and the Fire Creek Siltstone and lower Shublik Formation at Fire Creek (right). Illustrated in the figure are sequence boundaries (SB), the maximum flooding surface ( $\mathrm{mfs}$ ), the transgressive systems tract (TST), and highstand systems tract (HST). Also illustrated, to the right of each measured section, are field-collected scintillometer or gamma ray data. See figure 11 for key to symbols and patterns. 


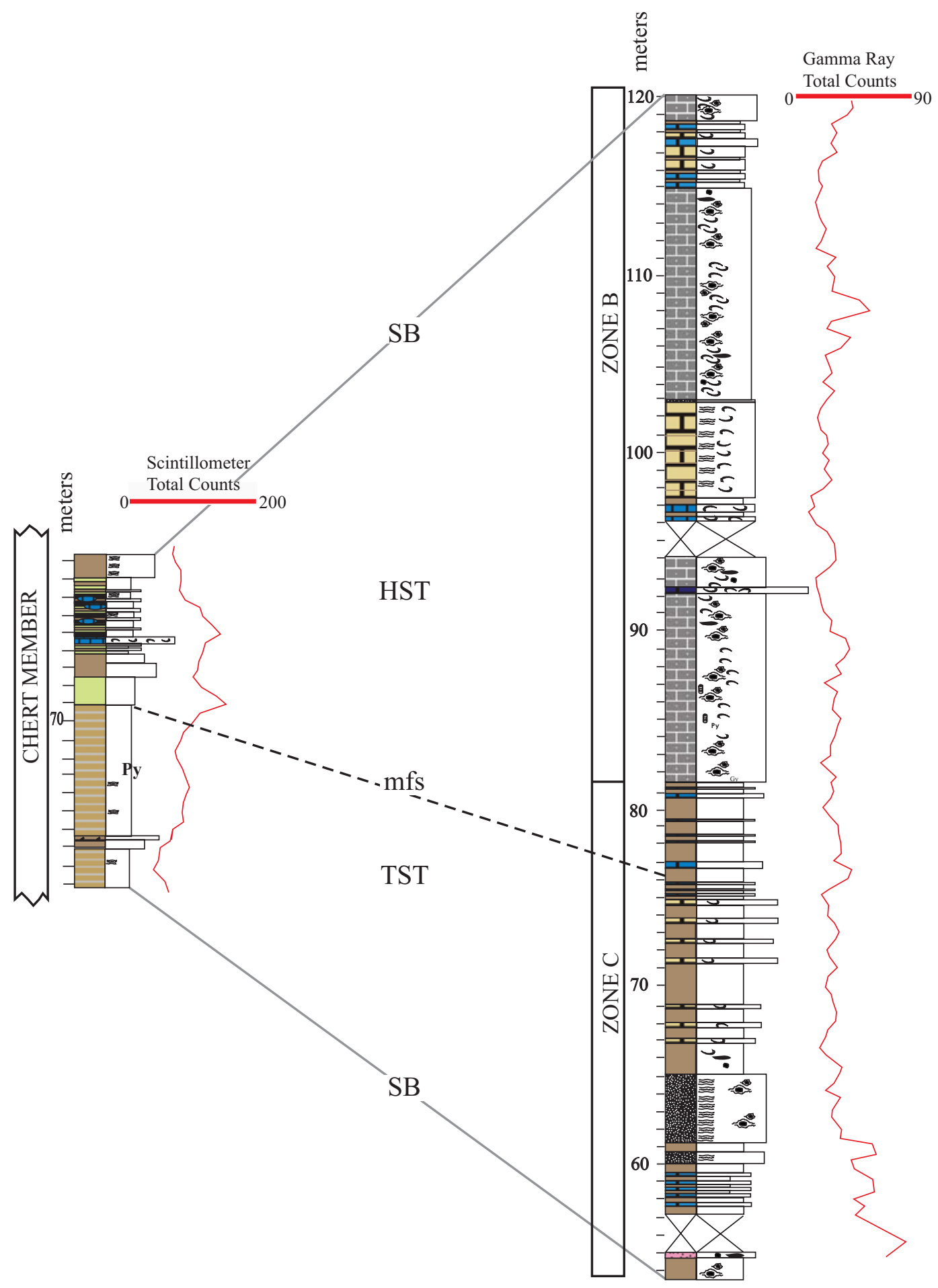

Figure 9. Correlation of sequence two between the middle Otuk Formation at Tiglukpuk Creek (left) and the lower to middle Shublik Formation at Fire Creek (right). Illustrated are sequence boundaries (SB), the maximum flooding surface (mfs), the transgressive systems tract (TST), and the highstand systems tract (HST). Also illustrated, to the right of each measured section, are field-collected scintillometer or gamma ray data.. See figure 11 for key to symbols and patterns. 


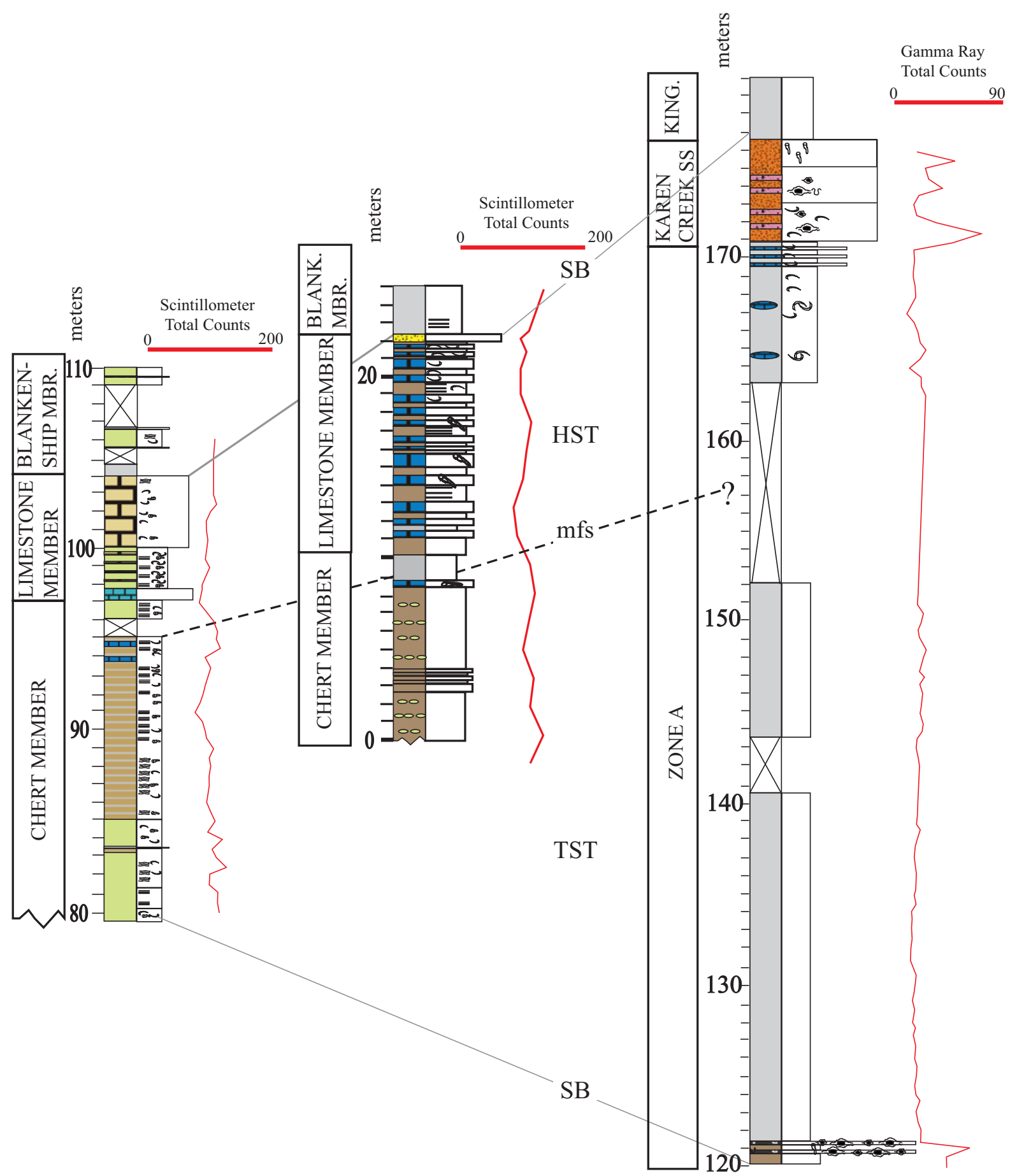

Figure 10. Correlation of sequence three between the upper Otuk Formation at Tiglukpuk Creek (left) and Atigun Gorge (center) and the upper Shublik Formation at Fire Creek (right). Illustrated are sequence boundaries (SB), the maximum flooding surface (mfs), the transgressive systems tract (TST), and the highstand systems tract (HST). Also illustrated, to the right of each measured section, are field-collected scintillometer or gamma ray data. See figure 11 for key to symbols and patterns. 


\section{SILICICLASTIC RETROGRADATIONAL FACIES ASSOCIATION}

The coarse-grained texture and rounded pebbles of the thin chert pebble conglomerate at the base of the Fire Creek Siltstone are indicative of a relatively highenergy depositional environment (figs. 5A, 8, 11). Crowder (1990) interprets the underlying Ledge Sandstone Member of the Ivishak Formation as a delta plain deposit. The conglomerate probably represents reworking of lowstand foreshore tidal and/or deltaic channel sediments during initial rise of sea level (Posamentier and Allen, 1999). The conglomerate quickly grades into pebbly medium- and fine-grained argillaceous quartz sandstone (facies 3) and then into dark gray siltstone (facies 4), which makes up the bulk of the Fire Creek Siltstone. Vertical burrows observed in the thin pebbly sandstone just above the conglomerate support a nearshore interpretation for these facies (Ekdale et al., 1984). Overlying the pebbly sandstone is a succession of parallel laminated siltstone (facies 4) characterized by burrows, bioturbation, tabular cross bedding and HCS (figs. 6A, 7A). These features are usually associated with deposition in an inner shelf environment (Duke et al., 1991; Cheel, 1991; Ekdale et al., 1984). The change from nearshore to shelf environments indicates that the Fire Creek Siltstone is a siliciclastic retrogradational facies association.

\section{SILICICLASTIC, PHOSPHATIC PROGRADATIONAL FACIES ASSOCIATION}

The next facies association is represented by the upper portion of the Fire Creek Siltstone and zone D of the Shublik Formation (figs. 8, 11). The base of the Shublik Formation is sandstone with abundant phosphatic nodules, horizontal to subhorizontal burrows, and disseminated pyrite nodules. The remainder of the unit consists of phosphatic sandstone (facies 9) and pebbly phosphorite (facies 10) interbedded with thin siltstone (facies 4) and phosphatic siltstone (facies 9). Layers of rounded to subrounded phosphatic pebbles from 10 to $20 \mathrm{~cm}$ in thickness occur approximately every 1 to $3 \mathrm{~m}$ and commonly display graded bedding (fig. 5J, K). Upward through zone $\mathrm{D}$ the number and frequency of pebble layers increases in conjunction with an increase in pebble and sand grain size. This package also displays local tabular cross bedding and HCS (fig 6A). The relatively coarse grain size and sedimentary structures of zone D are characteristic of deposition in an inner shelf environment (Duke et al., 1991; Cheel, 1991; Ekdale et al., 1984; Föllmi, 1990). The increase in frequency of phosphatic pebble layers and of pebble and sand grain size indicates a relative increase in energy and shallowing on the inner shelf and indicates this succession is a phosphatic progradational facies association.

\section{MIXED SILICICLASTIC, CARBONATE, PHOSPHATIC RETROGRADATIONAL FACIES ASSOCIATION}

The next facies association consists of interbedded siltstone (facies 4), wackestone (facies 6), argillaceous limestone (facies 7), and sandy phosphorite (facies 12) and makes up most of zone $\mathrm{C}$ of the Shublik Formation at Fire Creek ( 23 m thick; figs. 9, 11). The base of the association is marked by a transition from pebbly phosphorites and phosphatic sandstone to siltstone and thin beds of argillaceous limestone. Overlying the initial fine-grained facies is wavy bedded, grain-supported, rounded to well-rounded, medium-grained sandy phosphorite (facies 12) interpreted as a condensed section. The sandy phosphorite grades into a thick package of dark gray to black siltstone (facies 4) with thin (decimeter scale) layers of silty, bioclastic, argillaceous limestone (facies 7) and wackestone (facies 6).

Megafossils found in this study were not biostratigraphically useful, however Detterman et al. (1975) documented occurrences of Daonella frami, Lima sp., Camptonectes sp., and spiriferid brachiopods from the lower portion of this section. The fauna and fine-grained nature of the unit imply that deposition took place in middle to outer shelf depositional environments. The generally fining and thinning upward silty bioclastic limestones imply retrogradation and we classify the unit as a mixed siliciclastic, carbonate, and phosphatic retrogradational facies association.

\section{CARBONATE, PHOSPHATIC PROGRADATIONAL FACIES ASSOCIATION}

This facies association is comprised of phosphatic wacke/packstone (facies 8), pebbly and nodular phosphorite (facies 10 and 11), wackestone (facies 6), silty limestone (facies 7), and siltstone (facies 4), and represents upper zone C (5 m thick) and zone B (38.5 m thick) of the Shublik Formation (figs. 9, 11). The lower portion is dominated by phosphatic wackestone with minor phosphatic packstone and bivalve and brachiopod shells, internal phosphatic molds of gastropods, bivalves, and brachiopods, and minor crinoid stem fragments, occurring as pristine phosphatized particles and condensed phosphatic sediments. Most original shell material in this facies has been replaced by carbonate fluorapatite and/ or pyrite. Pyrite and phosphatic nodules are common throughout the section (figs. 5K, L). The phosphatic 
nodules are locally concentrated in layers that coarsen upward. These layers are interpreted as condensed phosphatic sediments. Nodules range in size from pebble to gravel, with pebble being the predominant size. Bedding thickens and begins to pinch and swell and become more silt-rich up section. Near the top of zone B, the limestone becomes more massive and contains more bioclasts and larger phosphate nodules. The top of zone $\mathrm{B}$ is marked by a change from the massive phosphatic limestone to shale facies (fig. 11).

Bioclastic grains and bioturbation are common throughout the association, but are more frequently observed in the upper portions. Based on lithofacies and fauna, upper zone $\mathrm{C}$ and zone $\mathrm{B}$ indicate the initiation of a carbonate ramp deposited in a middle shelf or ramp environment (Burchette and Wright, 1992). Carbonate ramps generally show little change in facies as a result of fluctuations in sea level (Burchette and Wright, 1992). The most obvious change in facies occurs during sea level rise, as carbonate ramps are easily drowned and deposition of siliciclastic facies takes over (Burchette and Wright, 1992). The presence of pristine condensed and allochthonous phosphatic sediments indicates that deposition occurred under fluctuating hydrodynamic conditions. The increasing nodule size, increase in bedding thickness, increase in carbonate content, and more abundant bioclasts and bioturbation upward through the section imply that this is a progradational phosphatic carbonate ramp facies association.

\section{SILICICLASTIC, PHOSPHATIC RETROGRADATIONAL FACIES ASSOCIATION}

The next Shublik Formation facies association consists of siltstone (facies 4), mudstone and shale (facies 5) and nodular phosphorites (facies 11) of lower zone A ( 38 m thick; figs. 10, 11). Poor exposure and weathering obscure many sedimentary textures and stratigraphic features. The nodular phosphorite layers are interpreted as hybrid phosphatic sediments that were deposited through multiple phosphatization events during a period of very low sedimentation rates (Föllmi et al., 1991). Overlying the nodular phosphorites are $50 \mathrm{~m}$ of light gray fissile mudstone and shale (facies 5). A thick covered interval prevents an accurate estimate of the stratigraphic position of the top, and hence the thickness of this facies association. Based on lithology, this association is interpreted as a middle to outer shelf deposit. The shift in facies from siltstone to nodular phosphorite implies condensation likely related to transgression. The change to shale deposition further supports a retrogradational interpretation. This facies association is thus interpreted to represent marine transgression, complete drowning of the underlying carbonate ramp, and a shift back to dominantly siliciclastic sedimentation in a siliciclastic, phosphatic retrogradational facies association.

\section{SILICICLASTIC, CARBONATE, PHOSPHATIC PROGRADATIONAL FACIES ASSOCIATION}

The last facies association at Fire Creek consists of mudstone and shale (facies 5), argillaceous limestone (facies 7), phosphatic sandstone (facies 9), and medium sandstone (facies 2) of the uppermost Shublik Formation and Karen Creek Sandstone (figs. 10, 11). The mudstone and shale are laminated to thinly bedded and contain abundant phosphatized bivalves in the upper portion (fig. 6G, H). The lack of current or wave-induced structures indicates that this facies was deposited on the outer or deep middle shelf. The upper $8 \mathrm{~m}$ of the Shublik Formation contains several light gray, fossiliferous, argillaceous limestone lenses and beds (figs. 10, 11). The overlying phosphatic sandstone contains large bivalves with internal phosphatic molds and original shells that are partially phosphatized and interpreted as pristine phosphatic particles. The uppermost medium sandstone contains vertical burrows (fig. 6D), indicating that deposition of this facies took place in middle to inner shelf depositional environment under the influence of tides (Swift et al., 1991; Ekdale et al., 1984; Föllmi, 1990; Föllmi et al., 1991). The transition from mudstone and shale to interbedded shale and limestone, to phosphatic and medium sandstone indicates shoaling upward and progradation. A progressive coarsening upward trend in grain size, increasing abundance of shelly fauna, and vertical burrows in the uppermost sandstone supports the interpretation of this unit as a siliciclastic, carbonate, phosphatic progradational facies association.

\section{SILICICLASTIC, SILICEOUS RETROGRADATIONAL FACIES ASSOCIATION}

The association of interbedded siltstone (facies 4), silty limestone or dolostone (facies 7), shale (facies 5), chert (facies 13), and porcelanite (facies 14) was documented in three different parts of the Otuk Formation. The lowermost example is dominantly siliciclastic while the remaining two are mostly siliceous facies. The lower example is within the Otuk shale and lower chert members (33-51m, fig. 8) and grades upward from alternating black and green siltstone and silty limestone and dolostone to thinly interbedded shale and porcelanite (figs. 8, 11). Burrows are present throughout, although they are not abundant. No indications of current activity were observed within these units, as all of the facies are parallel bedded, leading to the conclusion that these are 
hemipelagic sediments deposited in a marginal basin environment (Jones and Murchey, 1986). The other two examples of this facies association show only a slight gradation from chert or porcelanite (with minor siliciclastic material) to chert (with very little to no siliciclastic components) and consist of the middle chert member (64-71 m, fig. 9) and the uppermost chert member (80$95 \mathrm{~m}$, figs. 10, 11). These facies are also burrowed and parallel bedded, indicating deposition in a marginal basin-to-basin plain environment (Jones and Murchey, 1986). A decrease in the grain size and amount of siliciclastic material upward through these facies associations supports a retrogradational interpretation.

\section{SILICICLASTIC, SILICEOUS PROGRADATIONAL FACIES ASSOCIATION}

An association of chert (facies 13), porcelanite (facies 14), shale (facies 5), wacke/packstone (facies 6), and siltstone (facies 4) was documented in the lower to middle part of the chert member (51-61 m, figs. 8, 11) and the upper middle part of the chert member (71-79 m, figs. 9, 11). This facies association generally shows depositional patterns opposite to those of the siliciclastic, siliceous retrogradational facies association, grading from chert and porcelanite facies into more siliciclastic shaly and silty facies. Bedding is parallel with minor erosive bedding contacts, and burrows are common, thus the siliciclastic, siliceous progradational facies association was deposited in an outer shelf to marginal basin environment (Jones and Murchey, 1986). An increase in the size and amount of siliciclastic material upward through this facies association supports the interpretation that this is a siliciclastic, siliceous progradational facies association.

\section{CARBONATE PROGRADATIONAL FACIES ASSOCIATION}

The association of shale (facies 5), porcelanite (facies 13), argillaceous limestone (facies 7) and wacke/ packstone (facies 6) occurs in the uppermost chert member and limestone member of the Otuk Formation (figs. 10, 11). This facies association grades from thinly interbedded shale and porcelanite to argillaceous limestone and wacke/packstone. These facies are all parallel bedded and contain abundant bivalves, horizontal burrows, and bedding plane traces indicating that it was deposited in an outer shelf environment (Jones and Murchey, 1986; Burchette and Wright, 1992). The general increase in grain size, thickening upward trend in limestone facies, and increase in abundance of shelly fauna support a progradational interpretation.

\section{SEQUENCE STRATIGRAPHY}

Sequence stratigraphy has become a standard method for analysis of sedimentary successions that form in response to changing relative sea level. Sequence stratigraphic subdivision proceeds through the identification of a hierarchy of stratigraphic elements including sequences that are subdivided into systems tracts that represent specific phases during a rise and fall of relative sea level (Van Wagoner et al., 1988). Systems tracts are subdivided into shallowing-upward, marine floodingsurface bounded sedimentary cycles referred to as parasequences (Van Wagoner et al., 1988).

\section{SEQUENCES AND SYSTEMS TRACTS}

Grouping genetically related sedimentary facies into facies associations is a way of linking lithofacies that make up a depositional system (Collinson, 1969), and allows interpretations to be made about the specific depositional environments. Sequence stratigraphy subdivides stratigraphic successions into chronostratigraphically significant packages that are bounded by unconformities or correlative conformities (Van Wagoner et al., 1988). Unconformities, stratal geometries, and facies stacking patterns provide crucial evidence of relative sea level change and are key features used to define depositional sequences and systems tracts deposited during different stages of relative sea level. Sequence stratigraphy is a powerful tool because it permits predictions of facies stacking patterns where geological data are limited.

A lowstand systems tract (LST) is indicated by a significant basinward shift in facies and progradation of a basin-restricted wedge. It will lie above a surface correlative with a significant updip subaerial exposure surface and unconformity (type 1 sequence boundary). A shelf margin systems tract (SMST) is similar but lies above a surface correlative with an updip unconformity that does not represent significant subaerial exposure (type 2 sequence boundary). SMSTs typically display an aggradational facies stacking pattern indicating relative still-stand of sea level.

Retrogradation of facies is characteristic of transgressive systems tracts (TSTs) that overlie either LSTs or SMSTs. Thinning and fining upward facies indicate progressive deepening up to a maximum flooding surface (mfs). Some TSTs and maximum flooding intervals are associated with very slow rates of sedimentation and commonly result in condensed sections and locally the development of hardgrounds (Loutit et al., 1988; Posamentier and Allen, 1999). Phosphatization and glauconitization are common mineralization processes within such intervals (Loutit et al., 1988; Föllmi, 1990). The maximum flooding surfaces recognized in this study locally coincide with an elevated gamma ray response 
due to slow deposition and development of a condensed section allowing naturally occurring radioactive elements (K, Th, and U) to become concentrated in the sediment. Shelf-wide progradational facies stacking patterns indicate highstand systems tracts (HSTs) deposited after maximum flooding. Relative fall in sea level after deposition of an HST initiates development of a new sequence boundary and the extent of subaerial exposure will determine whether the HST is overlain by a LST or SMST. Once systems tracts are identified, they are grouped into depositional sequences bounded by proximal unconformities or more distal correlative conformities (Van Wagoner et al., 1988). The sequence stratigraphic model and terminology described here are in widespread use today (Loucks and Sarg, 1993; Weimer and Posamentier, 1994; de Graciansky et al., 1998; Harris et al., 1999; Posamentier and Allen, 1999).

One major difference between the sequences we have defined and those of the standard sequence stratigraphic model (Vail et al., 1977; Van Wagoner et al., 1988; Posamentier and Allen, 1999) is that each sequence lacks evidence of either a LST or SMST. The TSTs that we have identified commonly contain evidence of reworking and it is likely that LST or SMST deposits were reworked during subsequent transgression. The sequences defined here are thus bounded by transgressive surfaces that are indicated by abrupt changes in facies from more coarse-grained late HST deposits to finergrained TST deposits.

\section{SEQUENCE STRATIGRAPHIC INTERPRETATIONS}

\section{SEQUENCE 1}

Sequence 1 at Fire Creek is $53.5 \mathrm{~m}$ thick and consists of the Fire Creek Siltstone and zone D of the Shublik Formation (figs. 8, 11). The lower boundary is marked by an erosive surface at the top of the Ledge Sandstone Member of the Ivishak Formation, which is overlain by the thin conglomerate at the base of the Fire Creek Siltstone. This is the only type 1 sequence boundary within the entire succession. The upper boundary of sequence 1 is marked by an abrupt change from phosphatic sand and pebbly phosphorite to silty shale at $53.5 \mathrm{~m}$ that is interpreted as a transgressive surface. The thin conglomerate and pebbly sandstone at the base of the Fire Creek Siltstone is interpreted as a transgressive lag, deposited during incision of the shelf and reworking of upper shelf sediments during lowstand and early transgression. The pyritization that characterizes the conglomerate was most likely mediated by sulfur-reducing bacteria in a dysoxic or anoxic marine environment. Overlying thin-bedded argillaceous sandstones displaying HCS interbedded with parallel bedded or laminated siltstone likely represent periodic storm and storm relaxation or fairweather shelf deposition, respectively (Duke et al., 1991; Cheel, 1991). The generally fining upward nature of this package bolsters its interpretation as a siliciclastic retrogradational facies association and a TST.

The Fire Creek Siltstone displays low to moderate but fluctuating gamma ray response related to interbedding of sandy and more clay-rich facies. Gamma ray response is relatively low and does not provide evidence of condensation during maximum flooding. A series of cycles consisting of generally thinning upward sandstone beds to about $26 \mathrm{~m}$ in the section is interpreted to indicate a maximum flooding surface (mfs). Above this level sandstones become thicker, indicating progressively more proximal depositional environments. The remainder of the Fire Creek Siltstone and zone D of the Shublik Formation make up the siliciclastic, phosphatic progradational facies association that is interpreted as a HST. This package consists of two cycles or parasequences (32-45 $\mathrm{m}$ and $45-53.5 \mathrm{~m}$ ). Each is characterized by a general increase in grain size and frequency of pebbly phosphorites upsection indicating shoaling and regression. The lower portions of the cycles contain siltstone or phosphatic siltstone and sandstone while the upper portions are characterized by phosphatic sandstone and pebbly phosphorites. Similar phosphorite beds were observed in the Meade Peak Member of the Phosphoria Formation (Whalen, 1996; Hiatt and Budd, 2003). Phosphorite beds from both the Phosphoria and Shublik Formations are grain supported, usually overlie a sharp erosional surface, locally exhibit a coarse sand or pebble lag and a poorly defined fining-upward texture and are commonly bioturbated (Hiatt and Budd, 2003; this study).

Abundant phosphate nodules and cementation at the top of zone D, also noted by both Detterman et al. (1975) and Parrish et al. (2001a), indicate that it is a hardground, implying a hiatus in sedimentation. The outcrop gamma ray profile records a low but fluctuating gamma response with a peak at the hardground surface (fig. 8) supporting this interpretation.

Sequence 1 at Tiglukpuk Creek is $28 \mathrm{~m}$ thick and consists of the upper shale member and lower chert member of the Otuk Formation (figs. 8, 11). The lower boundary (correlative conformity to the type 1 sequence boundary at Fire Creek) is marked by the last thin silty dolostone unit at $33 \mathrm{~m}$ in the section within a dominantly siltstone succession. Identification of the lower boundary of sequence 1 is equivocal due to the lack of biostratigraphic control. The dolostone bed marks the top of a thickening upward succession in the lower part of the shale member that we interpret as the last package deposited at the end of a progradational episode most likely coeval with deposition of the more proximal Ledge 
Sandstone Member of the Ivishak Formation. A thin layer of bioclastic wackestone marks the upper boundary of sequence 1 at Tiglukpuk Creek (60 m, fig. 8).

The upper portion of the shale member consists of argillaceous sandstone and siltstone that grade upward into porcelanite, indicating progressive deepening. This interval is thus a siliciclastic, siliceous retrogradational facies association and is interpreted as the TST of sequence 1 . An abrupt change from interbedded porcelanite and siltstone facies to chert at about $51 \mathrm{~m}$ indicates a cessation in siliciclastic input during transgression and is interpreted as a mfs. Maximum flooding marks the beginning of a siliciclastic, siliceous progradational facies association characterized by chert, mudstone, siltstone, and a thin layer of bioclastic limestone. Mudstone and siltstone facies indicate a reinitiation of siliciclastic deposition. A half-meter-thick package of decimeter bedded siltstone, just below the bioclastic limestone, displays a thickening and coarsening upward trend. The facies relationships and general increase in grain size indicate a general shallowing and the interpretation of this package as a HST. Sequence 1 of the Otuk Formation is not exposed at Atigun Gorge.

\section{SEQUence 2}

Sequence 2 at Fire Creek is $66.5 \mathrm{~m}$ thick and consists of zones $\mathrm{C}$ and $\mathrm{B}$ of the Shublik Formation (figs. 9, 11). The lower boundary (at $53.5 \mathrm{~m}$ ) is marked by a change from phosphatic sandstone and pebbly phosphorites, with sedimentary features and bioturbation indicative of a high-energy environment, to interbedded siltstone and thin limestone, indicating deepening and less siliciclastic input. The upper boundary of sequence 2 is marked by an abrupt change from massive phosphatic wackestone to interbedded mudstone and silty shale at $120 \mathrm{~m}$ in the section (fig. 11).

The deepening recorded at the base of sequence 2 is characterized by a significant increase in gamma ray response and results in deposition of the siliciclastic, carbonate, and phosphatic retrogradational facies association. The lower $7 \mathrm{~m}$ of the package is dominated by siltstones with thin argillaceous limestone interbeds. A 5-m-thick interval of sandy phosphorite begins at $60 \mathrm{~m}$ in the section. This is interpreted as a phosphatic condensed section, deposited in a moderate energy environment during transgressive reworking of inner shelf sediments. Retrogradation is apparent as the facies shift from sandy phosphorite to cycles of siltstone with isolated, thin interbeds of wackestone. These cycles generally thicken upward while wackestone beds generally thin upward, indicating deepening and increasing accommodation space. The retrogradational character of this unit indicates that it is a TST. Maximum flooding is interpreted to lie within the upper part of Shublik Formation zone C, where there is a positive gamma ray response at $77 \mathrm{~m}$ in the section.
Overlying the mfs is a 43-m-thick package dominated by phosphatic carbonates with minor amounts of siltstone and argillaceous limestone that makes up uppermost zone $\mathrm{C}$ and zone B of the Shublik Formation. Much of zone B is massive and forms a prominent cliff face, but the siltstone and argillaceous limestone units display a more recessive weathering pattern. Uppermost zone $\mathrm{C}$ and zone $\mathrm{B}$ record three parasequences dominated by massive phosphatic limestone units that are underlain by mudstone or siltstone and interbedded argillaceous limestone. Flooding events at parasequence boundaries caused a decrease in carbonate production, and fine-grained siliciclastics and argillaceous limestones were deposited. Carbonate deposition ensued when the carbonate factory prograded seaward. The phosphatic limestone units thin upsection, indicating decreasing accommodation space. This package thus represents a carbonate and phosphatic progradational facies association and is interpreted as the HST of sequence 2.

Sequence 2 at Tiglukpuk Creek is only 16 m thick and consists of the middle chert member of the Otuk Formation (figs. 9, 11). The lower sequence boundary is marked by an abrupt change from bioclastic limestone to chert at about $61 \mathrm{~m}$ in the section. The upper boundary of sequence 2 is marked by an abrupt change from chert nodule bearing siltstone to porcelanite at $79.5 \mathrm{~m}$ in the section.

The lower part of sequence 2 is $7.5 \mathrm{~m}$ thick and dominated by chert. The chert commonly contains burrows and thin shale interbeds preserve abundant impressions of Monotis bivalves. The cherty facies indicates a return to environments that were as deep as the deepest water facies in sequence 1 , indicating retrogradation. This siliciclastic, siliceous retrogradational facies association is interpreted as the TST of sequence 2 . An abrupt change from chert to porcelanite and a positive gamma ray response at about $71 \mathrm{~m}$ are interpreted to indicate a $\mathrm{mfs}$.

Overlying the $\mathrm{mfs}$ is an 8.5-m-thick unit, marked by a shift in facies from chert to porcelanite, which is much more heterogeneous than the underlying TST. The unit consists from base to top of porcelanite and siltstone, thin interbedded siltstone, porcelanite, and wackestone or argillaceous limestone lenses, and finally chert nodule bearing calcareous siltstone. The change from porcelanite to more siliciclastic and carbonate dominated facies indicates shoaling and progradation and this package is interpreted to comprise a siliciclastic, siliceous progradational facies association making up the HST of sequence 2. Sequence 2 of the Otuk Formation is not exposed at Atigun Gorge.

\section{SEQuence 3}

Sequence 3 at Fire Creek is $56.5 \mathrm{~m}$ thick and consists of zone A of the Shublik Formation and the Karen Creek Sandstone (figs. 10, 11). The lower boundary is 
marked by an abrupt change from phosphatic bioclastic wacke/packstone to thinly bedded or laminated siltstone at $120 \mathrm{~m}$ in the section. The upper boundary of sequence 3 is marked by the top of the Karen Creek Sandstone that is overlain by papery black shale of the Kingak Formation (figs. 10, 11).

The lower portion of sequence 3 contains several covered intervals but it appears to be dominated by laminated to thin-bedded mudstones and shales. Two prominent beds of nodular phosphorite that exhibit a high gamma ray response occur near the base of sequence 3 and are interpreted to be a winnowed condensed section (figs. 10, 11). The abrupt change in grain size at the sequence boundary, condensed phosphorites, and the fine-grained nature of subsequent deposits, indicate that this is a siliciclastic and phosphatic retrogradational facies association and it is interpreted as the TST of sequence 3. It appears that a significant period of nondeposition took place during the TST, indicated by the phosphatic condensed section. Similar phosphorites at the same stratigraphic position are documented in many subsurface wells (Hulm, 1999). Gamma ray response through the section shows little variation but the exact position of the mfs within zone A is likely obscured by a thick covered interval in the Fire Creek section (figs. $10,11)$. Due to the covered interval the exact thickness of the TST cannot be determined but it is between 32 and 43 m thick.

Just above the covered interval, facies stacking patterns record a change from shale with calcareous nodules to thin argillaceous limestone interbedded with shale to phosphatic sandstone and medium sandstone. The increasing grain size and influx of sand indicate that this is a siliciclastic, carbonate, and phosphatic progradational facies association and it is interpreted as the HST of sequence 3 . The HST is no less than $13.5 \mathrm{~m}$ thick and no more than $24.5 \mathrm{~m}$ thick.

Sequence 3 at Tiglukpuk Creek is $24.5 \mathrm{~m}$ thick and consists of the upper part of the chert member and the limestone member of the Otuk Formation (figs. 10, 11). Most of sequence 3 is also exposed in Atigun Gorge, including the upper part of the chert member and the limestone member that is capped by a thin unit of argillaceous sandstone that appears to be equivalent to the Karen Creek Sandstone (figs. 10, 11; Bodnar, 1989). The lower boundary of sequence 3 is marked by a facies change from chert nodule bearing siltstone to porcelanite at $79.5 \mathrm{~m}$ in the Tiglukpuk Creek section. The upper boundary of sequence 3 is inferred to be at the top of the limestone member at Tiglukpuk Creek and at the top of the thin sandstone at Atigun Gorge.

The lower portion of sequence 3 at Tiglukpuk Creek consists dominantly of porcelanite interbedded with thin black shales overlain by a 10 -m-thick chert unit. The decrease in siliciclastic content and dominance of chert indicates significant deepening and deposition of a siliciclastic, siliceous retrogradational facies association that is interpreted as the TST of sequence 3. The TST is $15.5 \mathrm{~m}$ thick, ending at $94 \mathrm{~m}$ in the section where an increased gamma response suggests a mfs. The partially exposed TST at Atigun Gorge is $10 \mathrm{~m}$ thick and includes flaggy-bedded siltstone, shale, and porcelanite, indicating a slightly more proximal setting. The mfs is marked by a shift in facies from siltstone to shale but the gamma response through this interval in the Atigun Gorge section displays only a slight increase (figs. 10, 11).

Lying above the TST at Tiglukpuk Creek is a 9-mthick package that consists of porcelanite, wackestone, and minor siltstone facies. A 1-m-thick covered interval separates the underlying chert from interbedded porcelanite and fossil-rich limestone facies of the lower limestone member. The percentage of porcelanite decreases upward as the facies changes to bioclastic wackestone and packstone. The change in facies indicates shoaling and deposition of a carbonate progradational facies association interpreted as the HST of sequence 3 .

At Atigun Gorge the HST of sequence 3 is $12.5 \mathrm{~m}$ thick and consists of interbedded siltstone and burrowed, argillaceous limestone capped by a 0.35-m-thick, well cemented, fine sandstone (Karen Creek Member; Bodnar. 1989). At both Tiglukpuk Creek and Atigun Gorge, the upper boundary of sequence 3 is overlain by black shale of the Blankenship Member.

\section{SEQUENCE STRATIGRAPHY, BIOSTRATIGRAPHY, AND SEA LEVEL HISTORY}

The Fire Creek Siltstone, Shublik Formation, and Karen Creek Sandstone and the laterally equivalent portion of the Otuk Formation were deposited from the Smithian to the end of the Norian. Depending on the geologic time scale used, this interval spans between about 32-35 (Palmer and Geismann, 1999) or 41-46 million years (Gradstein and Ogg, 2004). These rock units can be divided up into three depositional sequences based on identification of major flooding surfaces and facies stacking patterns. The average time of deposition for each of the sequences is thus about 10-15 million years, indicating that they are third order or high frequency second order sequences (Vail et al., 1977; Goldhammer et al., 1987). These sequences can be correlated from the subsurface northwest of Prudhoe Bay to the northeastern and central Brooks Range (fig. 11). A significant erosional unconformity is recorded only at the base of sequence 1 at Fire Creek. The base of sequences 2 and 3 are defined by fine-grained transgressive facies abruptly overlying more coarse-grained late highstand facies. 
The Triassic units in northern Alaska exhibit pronounced cyclicity at a variety of scales. Documented here are second or third order depositional sequences in the Shublik Formation and adjacent units and the Otuk Formation. These sequences comprise systems tracts with either non-cyclic intervals or higher frequency shoaling upward cycles bounded by marine flooding surfaces (parasequences). Cycles within the Shublik Formation sequences generally shoal upward from organic-rich shales or fine-grained siltstones through phosphatic sandstones or phosphatic limestones to limestones. Otuk Formation cycles begin with shales, organic-rich shales, or cherts and shoal upward through porcelanite, siltstone, and/or argillaceous/silty limestone or wacke/packstone facies.

Kupecz (1995) and Robison et al. (1996) published the first sequence stratigraphic analyses of the Shublik Formation and related units and both interpreted the succession as a single sequence. Kupecz (1995) examined core samples from 11 drill holes in the Prudhoe Bay field, and described erosional contacts at the base and top of the Shublik Formation as sequence boundaries. Using well-log and geochemical data and descriptions of continuous core from the Phoenix well, Robison et al. (1996) likewise defined only two sequence boundaries, one between the Ivishak Formation and Eileen Sandstone and the other at the top of the Shublik Formation. Kupecz (1995) describes two shallowing upward parasequences, within the Shublik Formation.

Based on well log analysis of 97 wells and detailed core description from ten of those wells, Hulm (1999) described two sequences and a partial third sequence, which encompass the Eileen Sandstone through a portion of the Sag River Sandstone in Prudhoe Bay and NPRA. He placed sequence boundaries at the base of the Eileen Sandstone, at the top of Shublik zone C, and at the base of the Sag River Sandstone. Application of sequence stratigraphic analysis in this study facilitates more accurate correlation of these units at the systems tract scale (fig. 11) and analysis of facies stacking patterns permitted us to refine the model of Hulm (1999). Parasequence correlations are more difficult to demonstrate due to some non-cyclic intervals and the tremendous facies heterogeneity of the units in question.

Condensed sections are important in correlation and sequence stratigraphic analysis (Loutit et al., 1988), because they often contain a higher-than-normal concentration of radioactive elements, which show up well on gamma ray logs. Kupecz (1995) recognized three condensed sections at Prudhoe Bay; one near the base of zone C and two within zone B. Robison et al. (1996) recognize only one condensed interval near the top of zone $C$ despite several other significant gamma ray excursions. Hulm (1999) recognizes two surfaces of maximum flooding and condensation; one at the top of zone
D and another at the top of zone B, both of which correspond to gamma ray peaks. In this study three condensed sections with elevated gamma ray response, interpreted to indicate maximum flooding and condensation, are recognized. These include the two documented by Hulm (1999) and a third near the top of Shublik zone A and the contact with the Karen Creek Sandstone. Interpretation of the last of these gamma ray peaks as a maximum flooding surface implies that a similar peak within the Sag River Sandstone (Hulm, 1999; Robison et al., 1996) are likely correlative. Hulm (1999) interpreted the Sag River Sandstone to represent a LST. Some authors have documented a gradational rather than abrupt contact between the Sag River Sandstone and the Shublik Formation (Bird, 1994; Barnes, 2001) although it is represented by an erosional unconformity in proximal areas and a glauconitic-phosphatic hardground in more distal locations. Barnes (2001) implied that rather than a LST overlying a type-1 sequence boundary, the Sag River/ Shublik transition likely represents deposition above a type-2 sequence boundary. Our interpretation of the lower part of Shublik zone A and the upper part of the chert member of the Otuk Formation as representing a TST is not at odds with the interpretation of Barnes (2001), although another possibility is that the very monotonous facies in the lower portion of sequence 3 represent a shelf margins systems tract with an overlying TST and HST. Maximum flooding is indicated by a minor gamma ray peak in the upper part of the chert member of the Otuk Formation. At Fire Creek, a thick covered interval may obscure the mfs (figs. 10,11). Much of the Sag River Sandstone in the subsurface would thus be interpreted to represent either a SMST and/or TST. The HST is represented by the upper part of Shublik Formation zone A and relatively thin package of sandstone and/or limestone in outcrop localities and by the upper Sag River Sandstone in the subsurface. The abrupt contact with the overlying Kingak Shale or Blankenship Member of the Otuk Formation indicates a significant transgressive surface and termination of sequence 3 .

\section{BIOSTRATIGRAPHY}

Biostratigraphic control for the outcrop sections investigated in this study includes macrofossils and foraminiferal biostratigraphic data. Our biostratigraphic data, in conjunction with published data from outcrop (Detterman et al., 1975; Bodnar, 1984; 1989; Mull et al., 1987) and the subsurface (Hulm, 1999; Blodgett and Bird, 2002), permit refinement of temporal correlations between the subsurface and outcrops in the Brooks Range.

The Fire Creek Siltstone was dated as Smithian in age (Detterman et al., 1975). Lower zone D of the Shublik Formation is Anisian to Ladinian (Detterman et al., 1975) but the presence of the bivalve Daonella frami 


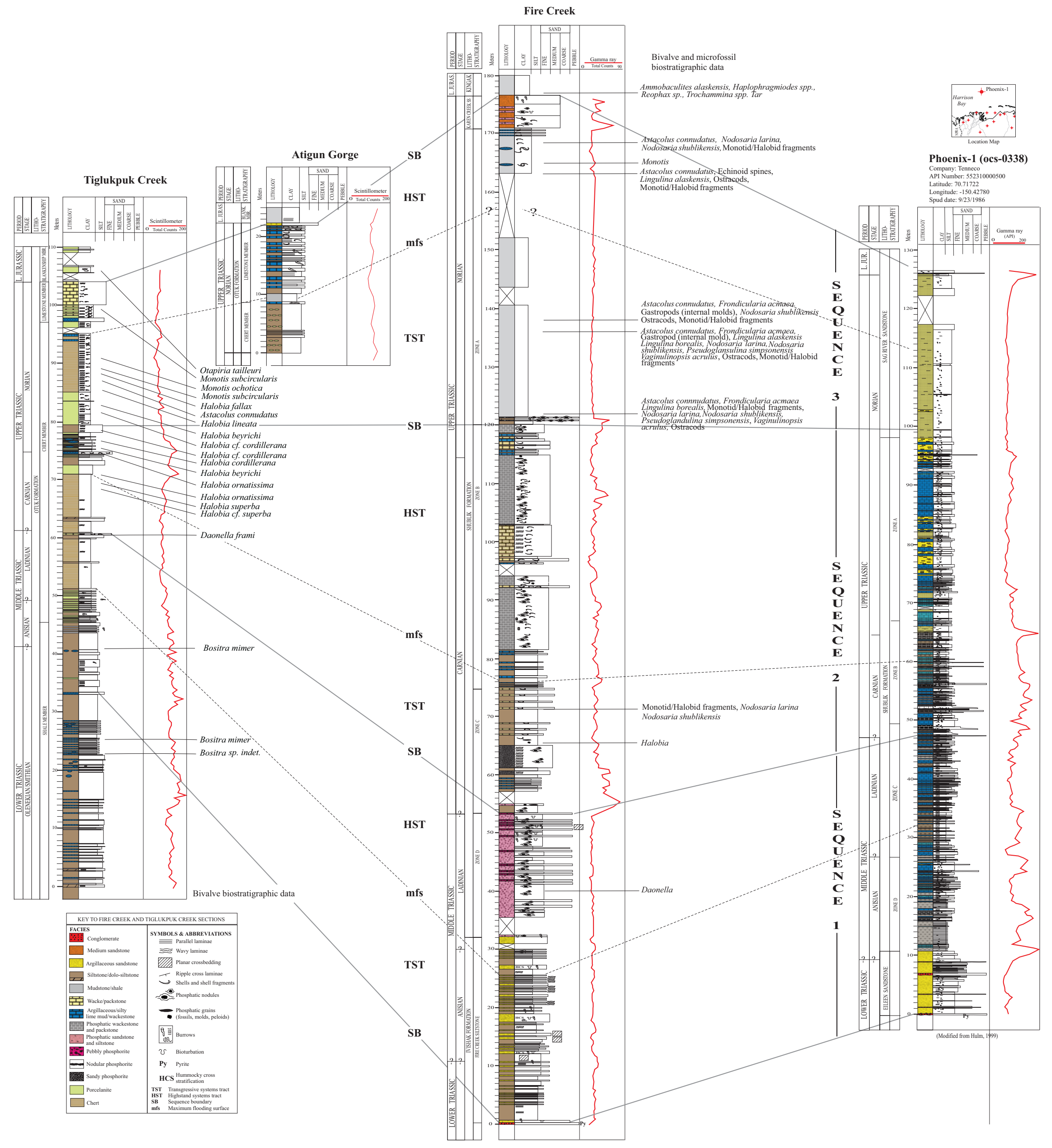

Figure 11. Sequence stratigraphic correlation of the Shublik and Otuk Formations and related units. Stratigraphic columns illustrate geologic age, lithostratigraphic units, Shublik Formation zonal subdivisions, thickness in meters, lithology, average grain size, and gamma ray response for Tiglukpuk Creek, Atigun Gorge, Fire Creek, and the Phoenix-1 subsurface well (the latter modified from Hulm, 1999). Sequence stratigraphic subdivisions and surfaces illustrated include transgressive (TST) and highstand systems tracts (HST), maximum flooding surfaces ( $\mathrm{mfs}$ ), and sequence boundaries (SB). 
This page has intentionally been left blank. 
confines rocks above about $40 \mathrm{~m}$ (lower zone D, Fire Creek section) to a Ladinian or younger age. Ages from the lower and middle parts of zone $\mathrm{C}$ are reported to be Ladinian (Detterman et al., 1975); however, foraminiferal analyses in this study identify probable Carnian fossils at 71.5 m (upper middle zone C, Fire Creek section). Foraminiferal analyses indicate that the probable boundary between the Carnian and Norian lies at about $94 \mathrm{~m}$ in the Fire Creek section and the rest of the Shublik Formation and Karen Creek Sandstone were deposited in the Norian. One foraminiferal sample taken a meter above the top of the Karen Creek Sandstone was Early Jurassic in age. Ages from Detterman et al. (1975) are largely correlative with the ages presented here but our data help refine some of the biochronology. Because biostratigraphic control at Fire Creek is insufficient to serve as a check on sequence stratigraphic correlations, the age relationships for sequences and systems tracts are largely derived from the Otuk Formation.

Bivalve biostratigraphy of the Tiglukpuk Creek section provides new age control for the Triassic section and improved correlations in this study (fig. 11). Initial transgression began after a relative low in sea level in the late Early Triassic, based on the occurrence of the bivalve Bositra mimer (just above 40 m; figs. 11, 12E). Daonella frami (fig. 12D), identified at $60.5 \mathrm{~m}$ in the section, is Ladinian in age. Halobia cf. superba, indicative of a Carnian age, was documented at $68 \mathrm{~m}$ in the section (fig. 11). The Ladinian-Carnian boundary is thus between 60.5 and $68 \mathrm{~m}$ in the section. Biostratigraphic resolution is not sufficient to accurately date the mfs but it is likely that the upper TST and HST of sequence 1 were deposited during the Ladinian stage. The base of sequence 2 approximates the Ladinian-Carnian boundary. The TST and lower HST of sequence 2 are entirely Carnian, while the uppermost HST was deposited in the lowermost Norian based on the stratigraphic position of the flat clam Halobia cf. beyrichi. The Carnian-Norian boundary is at $74.5 \mathrm{~m}$ in the section (based on Halobia ornatissima and Halobia beyrichi; figs. 11, 12C). The upper chert and limestone members were deposited during Norian time. Sequence 3 was deposited entirely during the Norian (fig. 11) and the top of the sequence is at or near the Triassic-Jurassic boundary as indicated by Jurassic foraminifera in the overlying Kingak Formation (Fire Creek) and Otapiria tailleuri in the Blankenship Member (105 m, Otuk Formation, Tiglukpuk Creek). The latter fossil was also reported in the Blankenship Member by Bodnar (1984).

\section{PALYNOLOGY}

In addition to bivalve biostratigraphy, we also performed palynological analysis on five samples from the Fire Creek Siltstone, three from Shublik Formation at Fire Creek, and four samples from the Otuk Formation at Tiglukpuk Creek to characterize the contained terrestrial and marine organic matter. The samples contain kerogen macerals, but the majority of the palynomorphs are highly degraded, indicating a high degree of thermal alteration that is confirmed by their dark brown to black color (Dorning, 1986) and $\mathrm{T}_{\mathrm{MAX}}$ values from Rock-eval. The organic particles are of both marine and terrestrial origin. Land-derived grains are mostly wood and plant tissue. Pollen and spores are minor components and they are comparatively small in size. The marine organics consist of algal matter, acritarchs and possibly dinoflagellate cysts. However, much of the kerogen is indeterminable, consisting of amorphous material that could be algal or bacterial matter as well as metabolic byproducts. Proportionally the largest group of marine palynomorphs is small acritarchs, mostly Micrhystridium spp. with round central bodies and spiny processes.

Terrestrial plant matter consists of small structured phytoclasts such as wood, cuticle, vascular (tracheid) tissue, and small leaf or stem fragments. The wood is irregularly fractured and displays evidence of pyritization. Some phytoclasts possess microscopic venation of 2-3 $\mu \mathrm{m}$ in diameter and may be derived from leaves. Pollen and spores are rare, but a few well-preserved spores and pollen grains were found. Cycadopites sp., a monosulcate pollen associated with cycads, but also collected from gingkophytes (Traverse, 1988), was positively identified. Bisaccate gymnosperm pollen, which is produced by conifers and distributed by wind, was abundant during the Triassic but is rare in the rocks of the Shublik and Otuk Formations. Only one specimen of Triadisporites sp., a bisaccate pollen affiliated with the Triassic conifer Darneya (Traverse, 1988), was recovered.

Among the spores identified with confidence are Stereisporites sp., Stereisporites (Distcyclosporis) trizonatus Schulz, Stereisporites antiquasporites (Wilson and Webster) Dettmann, Nevesisporites limbatus Playford, Limatulasporites sp., Limatulasporites limatulus (Playford) Helby and Foster, Carnisporites megaspiniger sp., Carnisporites spiniger Leschik, Anapiculatisporites telephorous (Pautsch) Klaus, Todites sp., Osmundacidites sp., Osmundacidites parvus de Jersey and, sparsely distributed, Cicatricosisporites sp. and Calamospora spp. Other poorly preserved spores could not be identified to the species level but appear to belong to the following form genera: Deltoidospora, Lophotriletes, Leiotriletes, Aratrisporites, Reticulitriletes, Verrucosisporites, Punctatisporites, and Ringosporites.

Botanic affiliations for some of these taxa are well established. Stereisporites, Nevisisporites, and Limatulasporites are bryophyte spores related to sphagnum moss (Traverse, 1988; Raine et al., 2005). Calamospora spores, although rare in the Triassic, were produced by 


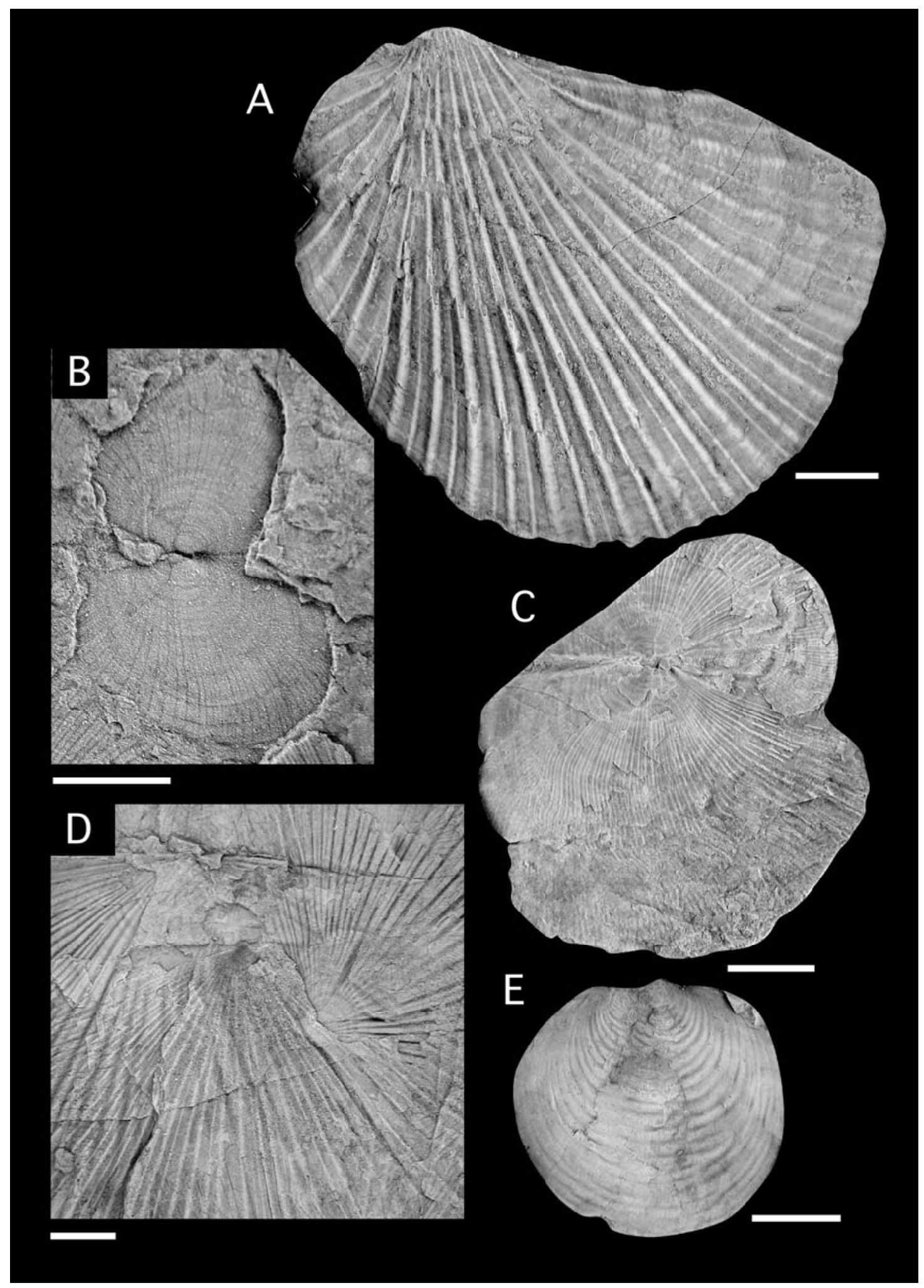


sphenopsids (Tschudy and Scott, 1969). Todites and Osmundacidites spores were obtained from osmundaceous ferns (Traverse, 1988; Raine et al., 2005). Carnisporites spores are thought to have come from Cynepteris ferns and Cicatricosisporites spores are affiliated with schizaeaceous ferns (Traverse, 1988). Cycads, bryophytes, and osmundaceous ferns thus produced most of the identified pollen and spores. Cycad pollen and the spores Cicatricosisporites and Stereisporites were found in the lower portions of both formations. There are, however, considerably fewer sporomorphs in the Otuk Formation, likely due to its more distal depositional environment.

Unfortunately, many palynomorphs remain unidentified due to the poor state of preservation. From these limited findings, a nearshore flora consisting in part of bryophytes, sphenopsids, ferns, fern trees, cycads, and possibly gingko trees is documented. The floral assemblage is suggestive of a temperate climate zone and the rarity of wind-distributed pollen implies that continental runoff rather than eolian processes likely delivered palynomorphs.

\section{SEA LEVEL}

Our sequence stratigraphic analysis forms the basis for construction of a relative sea level curve for the late Early through the Late Triassic (fig. 13). Based on facies stacking patterns and significant transgressive surfaces, we have identified three or possibly four sea level cycles. Based on the time represented they would be considered third order cycles (Vail et al., 1977). Previously published Triassic sea level curves (Embry, 1988; Haq et al., 1988) document additional relative or eustatic sea level events compared to the Triassic rocks of northern Alaska. The Embry (1988) and Haq et al. (1988) sea level curves display six sea level cycles from late Early Triassic through the Norian stage of the Late Triassic (fig. 13). The major discrepancies between our sea level curve and those of Embry (1988) and Haq et al. (1988) arise during the Carnian and older portions of the section. Embry (1988) and Haq et al. (1988) indicate that the Carnian is characterized by three sea level events and the late Early Triassic through the Ladinian record two events (fig. 13). We can only distinguish a single sea level event during the Early Triassic through the Ladinian. During the Carnian we may be able to break out two separate sea level events but this is a very condensed portion of the stratigraphic succession and we present this as an alternative (dashed line; fig. 13) to our interpretation of a single event during the Carnian. All three sea level curves are in agreement that the Norian is characterized by a single sea level event. The Rhaetian stage is not recognized in North America and the sea level rise recorded by the Blankenship Member of the Otuk Formation and the Kingak Formation (figs. 2, 13) juxtapose Hettangian (lowermost Jurassic) rocks directly above uppermost Norian facies.

A possible explanation for the discrepancy in number of recorded sea level events could lie in the low angle nature of the Triassic depositional surface and the relatively distal setting of our outcrop sections. The laterally extensive (in both strike and dip directions) facies belts (fig. 1) support a broad, low gradient surface that would require significant changes in water depth to initiate a major change in facies that would be interpreted as a deepening or transgressive event. The distal, relatively deep setting, especially in the Otuk Formation, might also have caused some sea level events to go unrecorded (missed beats).

\section{GEOCHEMISTRY}

A total of 136 samples were analyzed for inorganic geochemistry, 27 samples were analyzed for sulfur content, 138 samples were analyzed for total organic carbon (TOC), 18 samples were analyzed by Rock-eval methods, and five samples were examined for vitrinite reflectance. Whole rock inorganic geochemical analyses are used to determine the abundances of common major oxide compounds. These analyses help in classification of chemically different rocks, an important aspect when dealing with rocks containing above average amounts of chemically precipitated material, such as phosphatic rock types (Hiatt and Budd, 2003).

The redox conditions at the time of sediment deposition play an important role in whether a rock will be a potential source rock, because anoxic waters favor the preservation of organic material (Demaison and Moore, 1980). As a general rule oil source rocks have $>1$ percent TOC and both the Shublik and Otuk Formations are proven source rocks (Hughes et al., 1985; Magoon and Bird, 1988; Bird, 1994). A reducing state just below the sediment-water interface at the time of deposition

Figure 12 (left). Representative and biostratigraphically significant bivalves from the Otuk Formation at Tiglukpuk Creek. Scale bar is $1 \mathrm{~cm}$.

A. Monotis subcircularis upper Norian Cordilleranus Zone, CM02TIG-31.

B. Halobia ornatissima, upper Carnian, CM02TIG-19.

C. Halobia cf. cordillerana, lower or middle Norian, CM02-TIG-6.

D. Daonella frami, lower Ladinian; CM02TIG-1.

E. Bositra mimer, Olenikian (Lower Triassic), CM02TIG-15. 
also allows certain trace metals to accumulate at higherthan-normal concentrations during development of condensed sections (Loutit et al., 1988; Quinby-Hunt and Wilde, 1996). Geochemical analysis of trace metal concentrations in rock samples from the Fire Creek and Tiglukpuk Creek sections are used to help determine the paleoredox conditions of marine bottom or pore waters penecontemporaneous with deposition. The trace metals vanadium, nickel, manganese, molybdenum, cadmium, cerium, copper, strontium, uranium, various rare earth elements, and manganese/calcium ratios (Breit and Wanty, 1991; Curiale, 1987; Mozley and Hoernle, 1990; Morford and Emerson, 1999; Quinby-Hunt and Wilde, 1996; Wenger and Baker, 1986; Hiatt and Budd, 2003; Shields and Stille, 2001) have all been proposed as proxies for the redox state of marine bottom or pore waters.

\section{ORGANIC GEOCHEMISTRY TOTAL ORGANIC CARBON (TOC)}

TOC values were highest in the Tiglukpuk Creek section (fig. 14) reaching up to 10.77 percent. The average TOC content for the entire Tiglukpuk Creek section

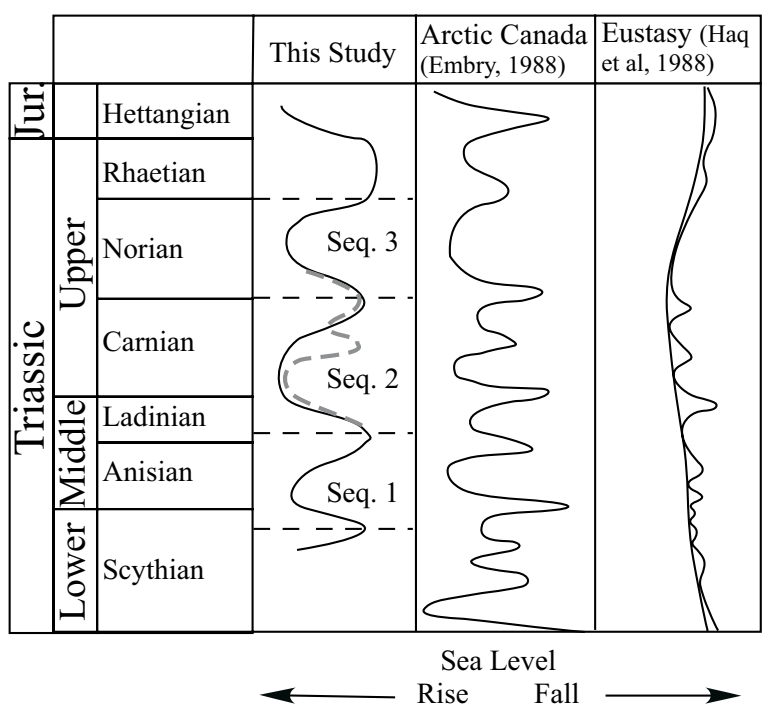

Figure 13. Sea level curves for the Triassic based on this study, rocks exposed in Arctic Canada (modified from Embry, 1988), and a eustatic curve modified from Haq et al. (1988). Note that we document a single rise and fall of sea level during the Anisian while Embry (1988) records two and Haq et al. (1988) document three. During the Ladinian through Carnian we document one (solid black line) or possibly two (dashed gray line) sea level events while both of the other curves imply three events. All three curves are in agreement that the Norian is characterized by a single rise and fall of sea level. is 2.87 percent. The total thickness of facies with $>2$ percent TOC in the Tiglukpuk Creek section is about $44.3 \mathrm{~m}$ and the total thickness of facies with $>5$ percent TOC is about $5.3 \mathrm{~m}$. The upper portion of the Otuk Formation that is exposed in Atigun Gorge includes at least $8 \mathrm{~m}$ of organic-rich facies with $>2$ percent TOC. The highest TOC value from the Atigun Gorge section (8.04 percent) is from the Blankenship Member. The most organic-rich rocks in the Otuk Formation (Tiglukpuk Creek and Atigun Gorge sections) occur in porcelanite and shale facies in all three sequences.

Compared to the Otuk Formation TOC content is much lower in the Shublik and associated units at Fire Creek (fig. 14) where the highest value was 3.53 percent. The average TOC content of the Fire Creek section is 1.07 percent. The total thickness of facies with $>2$ percent TOC in the Fire Creek section is less than $1 \mathrm{~m}$. The most organic-rich facies in the Shublik Formation at Fire Creek are within shale and siltstone that is interbedded with calcareous facies, and phosphatic wacke-stone and packstone facies in sequence 2 (fig. 14). The lower values in the Fire Creek section are probably a result of varying factors, which may include dilution of the organic matter by high sediment accumulation rates, sediment reworking and oxidation during times of very low sediment accumulation rates, and oxidation of organic matter during fluctuations of the oxygen minimum zone. Fine-grained facies at Fire Creek are very friable and surface weathering may also have affected TOC content. In contrast, many of the samples from Tiglukpuk Creek are siliceous and more resistant to weathering. Robison et al. (1996) report Shublik Formation TOC values in the Phoenix-1 well ranging from 0.5 percent to 10.2 percent while Kupecz (1995) reported values $>6$ percent for wells in the Prudhoe Bay subsurface. These high TOC values from the subsurface Shublik Formation may be a result of deposition within a restricted estuarine environment (Hulm, 1999) but also probably indicate better preservation of organic carbon in unweathered cores.

\section{ROCK-EVAL AND VITRINITE REFLECTANCE}

Eighteen samples from the Shublik and Otuk Formations were subjected to Rock-eval pyrolysis and five Otuk samples were analyzed for vitrinite reflectance. Within the oil window, the reflectance of vitrinite deposited in reducing marine or lacustrine environments is often lower (e.g., 0.15-0.55 VR $_{0}$ compared to vitrinite deposited in more oxic environments. This lower reflectance can be influenced by lipids incorporated into the vitrinite structure, vitrinite-like macerals derived from degradation of marine plants, migrated oil, and the generation of bitumen, among other causes (Waples, 1981). 
The results of Rock-eval and vitrinite reflectance on highTOC samples from the Shublik and Otuk Formations provide information about thermal maturity and the type of organic matter. Twelve samples from the Otuk Formation at Tiglukpuk Creek indicate that the $\mathrm{T}_{\mathrm{MAX}}$ ranges from $439^{\circ}$ to $453^{\circ} \mathrm{C}$ (table 3). Five samples from Atigun Gorge indicate that the $\mathrm{T}_{\mathrm{MAX}}$ ranges from $443^{\circ}$ to $450^{\circ} \mathrm{C}$ (table 3). All of the samples from the Otuk Formation fall within the oil window of petroleum generation. Results from the Shublik Formation indicate a $\mathrm{T}_{\text {MAX }}$ of $486^{\circ} \mathrm{C}$ (table 3 ). Kerogen in all Otuk samples was mainly

Fire Creek Section

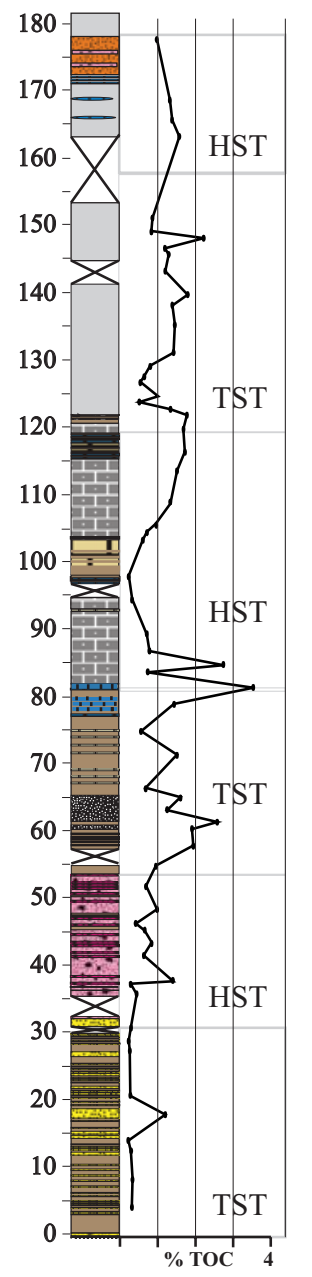

micrinized unstructured lipids and solid bitumen with small amounts of inertinite and vitrinite. Mean vitrinite reflectance $\left(\mathrm{VR}_{\mathrm{o}}\right)$ values for the Tiglukpuk Creek section range from 1.09 to 1.38 and one sample from the Atigun Gorge section had a value of 1.31, passing just into the wet gas phase of hydrocarbon generation (table 3). Rocks of the Otuk Formation are mature, falling within the middle oil to upper wet gas generation maturation fields. The single sample from Fire Creek falls into the more gas-prone region based on Rock-eval data (fig. 15). Rock-eval data on samples from all three exposures in the Brooks Range reinforce the interpretation of the degree of thermal maturity for these rock units (table 3, fig. 15).

Rock-eval and TOC analyses of rocks in the Phoenix well indicate that the lower to middle portion of the Shublik Formation is more organically enriched, has higher generation potential, and contains more oil-prone kerogen than the upper portion (Robison et al., 1996). This interval coincides with the upper TST and HST of sequence 1 and the TST and lower HST of sequence 2 (fig. 11). This corresponds reasonably well with TOC data from sequence 2 in the Fire Creek section but values are generally low in sequence 1. The Otuk Formation at Tiglukpuk Creek contains relatively organic-rich facies in all three sequences but the highest values are within sequence 3 rather than 2 . This pattern might indicate a progressive change in the locus of accumulation of organic matter from more proximal settings in sequence 1 to more distal areas in sequence 3 . Alternatively, this pattern could be influenced by increased proximal siliciclastic influx during the deposition of sequence 3 indicated by the thick mudstone and shale interval and Karen Creek Sandstone at Fire Creek and the Sag River Sandstone in the Phoenix well (fig. 11). This increased siliciclastic influx would have served to dilute the concentration of organic matter leading to lower TOC values in proximal settings within sequence 3 .

\section{INORGANIC GEOCHEMISTRY}

A total of 136 whole-rock samples were analyzed by XRF and ICP-MS for inorganic geochemistry. These analyses have provided a wealth of geochemical data for the Shublik and Otuk Formations. Only a selected suite of data is examined in detail for this study.

Gorge, and Tiglukpuk Creek sections. Note that the highest TOC values occur mainly in transgressive systems tracts (TSTs) and lower highstand systems tracts (HSTs). Highest values are found in the TST of sequence 3 of the Otuk Formation. See figure 11 for key to symbols and patterns. Some thin lithologic units cannot be illustrated at this scale. 


\section{CERIUM ANOMALY AND MANGANESE}

The elements cerium and manganese are both good indicators of penecontemporaneous paleoredox conditions in marine bottom or pore waters (Sholkovitz et al., 1994; Quinby-Hunt and Wilde, 1996; Shields and Stille, 2001). More specifically, cerium precipitates from seawater under reducing conditions (McLennan, 1989; Sholkovitz et al., 1994; Shields and Stille, 2001) and manganese precipitates from seawater under oxidizing conditions (Quinby-Hunt and Wilde, 1996). Cerium is the only REE that can undergo a redox transformation at ambient oceanic conditions (Goldberg et al., 1963; McLennan, 1989).

The Cerium anomaly $\left(\mathrm{Ce}_{\text {anom }}\right)$ is calculated based on the enrichment or depletion of Ce relative to the neighboring REEs La and Nd. Comparison among REEs is facilitated by normalizing their values to the North American Shale Composite (McLennan, 1989; Condie, 1991). $\mathrm{Ce}_{\mathrm{anom}}$ is related to the decrease in solubility that accompanies the oxidation of Ce(III) to Ce(IV), thus recording variations in the bottom water and/or porewater oxygenation. The equation for $\mathrm{Ce}_{\text {anom }}$ has not been standardized but the most commonly used algorithm is from Elderfield and Greaves (1982):

$$
\mathrm{Ce}_{\text {anom }}=\left(3 \mathrm{Ce} \mathbf{e}_{\mathrm{N}} /\left(2 \mathrm{La}_{\mathrm{N}}+\mathrm{Nd}_{\mathrm{N}}\right)\right)
$$

where " $N$ " signifies the shale-normalized concentration. The $\mathrm{Ce}_{\text {anom }}$ has been interpreted as a redox indicator (Wright et al., 1987; Wang et al., 1993; Macleod and Irving, 1996). In studies of apatite fossils REE uptake was demonstrated to occur during early diagenesis at or just below the sea floor (Wright et al., 1987; Sholokvitz et al., 1994). Cerium tends to precipitate with phosphatic and carbonaceous sediments and concentrations may be affected by diagenesis and weathering (Shields and Stille, 2001).

Due to the complexities of the system and potential diagenetic effects Shields and Stille (2001) advised caution when interpreting paleoredox conditions. Because of these complications we do not use the $\mathrm{Ce}_{\text {anom }}$ exclusively as a paleoredox indicator. In general, in modern oceans, most anoxic environments display a $\mathrm{Ce}_{\text {anom }}$ of zero or greater (Sholkovitz et al., 1992). In studies of ancient rock or fossils a $\mathrm{Ce}_{\text {anom }}$ of $<-0.1$ is considered indicative of oxic conditions while higher values indicate low oxygen conditions (Wang et al., 1993; MacLeod and Irving, 1996; Holser, 1997). However, a recent experimental study concluded that the Ce anomaly could not be used as a reliable proxy of redox conditions in organic-rich waters or in minerals that formed in equilibrium with organicrich waters (Davranche et al., 2005). Our TOC data (fig. 14) clearly indicate that rock units sampled here are commonly organic rich, calling into question the utility of the $\mathrm{Ce}_{\text {anom }}$ as a paleoredox indicator.

$\mathrm{Ce}_{\text {anom }}$ trends in the Fire Creek and Tiglukpuk Creek sections vary significantly but most are above 0.2 and would thus all appear to indicate anoxic environments (fig. 16). Some intervals with abundant bioturbation and high ichnofabric indices were clearly deposited under

Table 3. Rock-eval and vitrinite reflectance data. Table records sample numbers, weight percent total organic carbon (TOC), S1, S2, S3, $T_{\max }$, hydrogen index (HI), oxygen index (OI), S1/TOC, and vitrinite reflectance $\left(V R_{o}\right)$ values.

\begin{tabular}{|c|c|c|c|c|c|c|c|c|c|c|}
\hline Sample ID & $\begin{array}{c}\text { TOC } \\
\text { Wt. \% }\end{array}$ & $\begin{array}{c}\mathrm{S1} \\
\mathrm{mg} / \mathrm{g}\end{array}$ & $\begin{array}{c}\mathrm{S} 2 \\
\mathrm{mg} / \mathrm{g}\end{array}$ & $\begin{array}{c}\text { S3 } \\
\mathrm{mg} / \mathrm{g}\end{array}$ & $\mathbf{T}_{\max }$ & HI & OI & $\begin{array}{c}\text { S1/ } \\
\text { TOC }\end{array}$ & PI & $\mathrm{VR}_{\mathrm{o}}$ \\
\hline 1FC81.1 & 3.53 & 0.05 & 0.10 & 1.00 & 486 & 3 & 28 & 2 & 0.36 & \\
\hline TW34.3 & 4.05 & 0.41 & 2.25 & 0.30 & 441 & 56 & 7 & 10 & 0.15 & \\
\hline TW37.4 & 3.68 & 0.41 & 3.00 & 0.84 & 453 & 82 & 23 & 11 & 0.12 & \\
\hline TW46.3 & 6.79 & 0.88 & 9.88 & 1.05 & 443 & 146 & 15 & 13 & 0.08 & \\
\hline TW51.9 & 6.87 & 0.50 & 6.99 & 1.18 & 443 & 102 & 17 & 7 & 0.07 & 1.09 \\
\hline TW52.8 & 5.39 & 0.77 & 5.87 & 1.40 & 447 & 109 & 26 & 14 & 0.12 & \\
\hline TW53.15 & 6.15 & 0.55 & 6.35 & 1.15 & 445 & 103 & 19 & 9 & 0.08 & 1.14 \\
\hline TE7 & 5.19 & 1.10 & 6.53 & 0.73 & 442 & 126 & 14 & 21 & 0.14 & \\
\hline TE10.5 & 4.65 & 0.92 & 5.91 & 0.74 & 442 & 127 & 16 & 20 & 0.13 & \\
\hline TE13.6 & 7.78 & 1.47 & 13.49 & 0.96 & 444 & 173 & 12 & 19 & 0.10 & 1.38 \\
\hline TE14.6 & 4.19 & 0.76 & 3.19 & 0.80 & 439 & 76 & 19 & 18 & 0.19 & \\
\hline TE-26.2 & 5.24 & 0.87 & 7.64 & 0.51 & 443 & 146 & 10 & 17 & 0.10 & \\
\hline TE26.6 & 8.55 & 0.98 & 15.69 & 1.29 & 445 & 184 & 15 & 11 & 0.06 & 1.13 \\
\hline A-1 & 3.68 & 0.63 & 4.13 & 0.36 & 446 & 112 & 10 & 17 & 0.13 & \\
\hline$A-3$ & 4.03 & 0.94 & 5.47 & 0.41 & 444 & 136 & 10 & 23 & 0.15 & \\
\hline AG4 & 3.57 & 1.06 & 5.80 & 0.23 & 450 & 162 & 7 & 30 & 0.16 & \\
\hline AG12 & 8.04 & 1.47 & 16.16 & 0.43 & 443 & 201 & 5 & 18 & 0.08 & 1.31 \\
\hline A-17 & 6.42 & 1.35 & 10.16 & 0.62 & 445 & 158 & 10 & 21 & 0.12 & \\
\hline
\end{tabular}




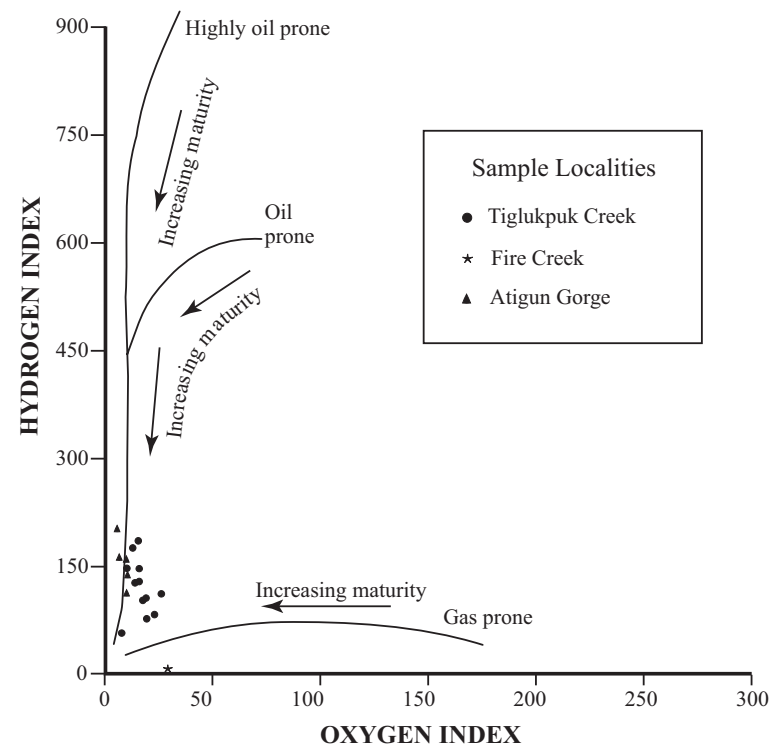

Figure 15. Van Krevelen diagram of hydrogen vs. oxygen index for samples from the three study areas. Note that all samples are mature and most plot in the oil-prone field except for one sample from the Shublik Formation.

oxic environments, suggesting that diagenesis played a role in the $\mathrm{Ce}_{\text {anom }}$ signature. The cerium anomaly thus does not provide unequivocal evidence of bottom water anoxia but we can gain insight into paleoredox conditions through other paleoredox indicators discussed below.

Manganese is another element with potential to provide insight into paleoredox conditions. Mn tends to precipitate as oxides or carbonates in oxic environments but is more soluble in low oxygen environments (QuinbyHunt and Wilde, 1996). Higher concentrations of Mn in the Fire Creek and Tiglukpuk Creek sections appear to indicate significant fluctuations in paleoredox conditions (fig. 16) with high values indicating oxic and low values low oxygen facies. A comparison between TOC and Mn (figs. 14, 16) reveals facies with high TOC content commonly have low Mn values, supporting the interpretation that these are relatively low oxygen facies.

\section{CALCIUM/MANGANESE RATIO}

Quinby-Hunt and Wilde (1996) demonstrated a relationship between the $\mathrm{Ca} / \mathrm{Mn}$ ratio of calcic black shales and pore water oxygenation. They defined four discrete groups that appear to indicate different levels of pore water oxygen content (fig. 17). A plot of the Ca/Mn ratio for samples from Fire Creek (fig. 17) indicate two main groups that appear to correspond to $\mathrm{Ca} / \mathrm{Mn}$ group 1 (oxic bottom water, mildly anoxic pore water) or group 2 (oxic-mildly anoxic bottom water, anoxic pore water) and $\mathrm{Ca} / \mathrm{Mn}$ group 3 or 4 (anoxic bottom and pore waters). In general, those in groups 1 and 2 were deposited within the Fire Creek Siltstone while those in groups 3 and 4 are in shale facies of the Shublik Formation. The Karen Creek Sandstone records a shift back to more oxic environments. $\mathrm{Ca} / \mathrm{Mn}$ ratios for the Tiglukpuk Creek section (fig. 17) show a consistent grouping in the anoxic phase (groups 3 and 4), but a more sporadic configuration outside of the anoxic phase including many outlying points. Higher $\mathrm{Ca} / \mathrm{Mn}$ ratio values commonly correspond to $\mathrm{Ce}_{\text {anom }}$ and $\mathrm{Mn}$ signatures indicative of low oxygen conditions (figs. 16, 17).

\section{PHOSPHORUS AND VANADIUM}

Breit and Wanty (1991) report that vanadium is concentrated in strongly reducing sediments while phosphate accumulations are the result of sediment reworking under slightly less reducing conditions. In the lower part of the shale member of the Otuk Formation, P and V co-vary (fig. 18). However, for samples from Fire Creek and the rest of the Tiglukpuk Creek Otuk section, V and P generally display either antithetical trends or are slightly offset (fig. 18). We interpret this pattern to indicate temporal fluctuations in oxygenation during or just after deposition with higher $\mathrm{V}$ contents indicating anoxic conditions and higher $\mathrm{P}$ signaling more oxic environments. Vanadium and phosphorus may thus be good indicators of the transition between anoxia and more oxic conditions and provide insight into the transit of the OMZ across the shelf.

\section{RARE EARTH ELEMENTS}

REE trends from the Fire Creek and Tiglukpuk Creek sections display very similar patterns (fig. 19) except in the TST of sequence 1 where the geochemical signatures are essentially opposite. Sequences 2 and 3 and the HST of sequence 1 display striking similarities in the values of REEs Dy, Er, Gd, and Yb (fig. 19). The Otuk Formation is much thinner and more condensed than the Shublik Formation and associated units and much tighter sampling would be necessary to document high-resolution correlations (parasequence scale). The general geochemical trends; however, do with few exceptions reinforce the correlations made based on facies stacking patterns and biostratigraphy. In general the covariation of REEs between widely spaced sections implies s that the patterns either record original depositional values or are the result of basin-wide diagenetic processes.

\section{RESULTS AND CONCLUSIONS}

\section{RESULTS}

Upper Lower to Upper Triassic sedimentary rocks of northern Alaska consist of a heterogeneous assemblage of facies. Observations of the rocks from outcrop sections and further investigation of hand samples in the 


\section{Fire Creek Section}

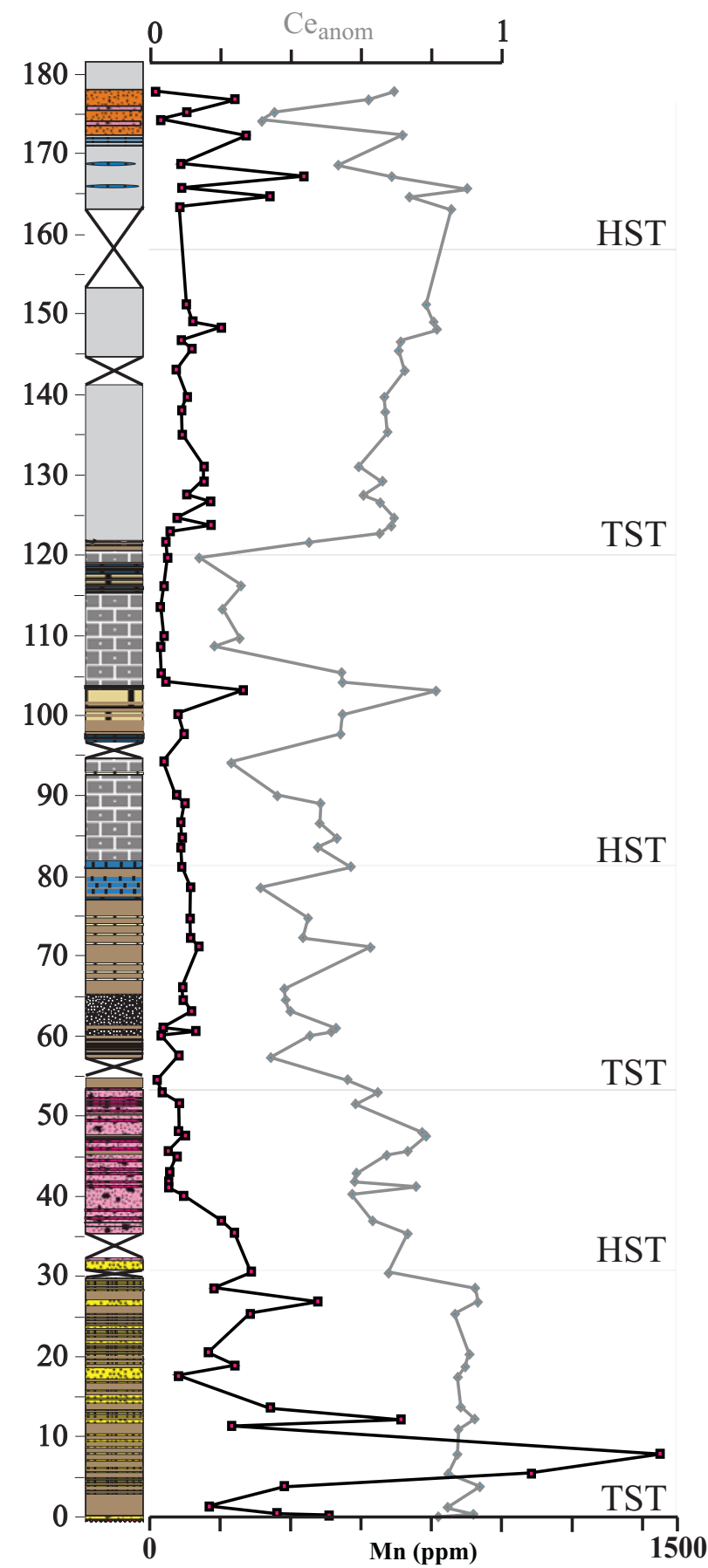

Tiglukpuk Creek Section

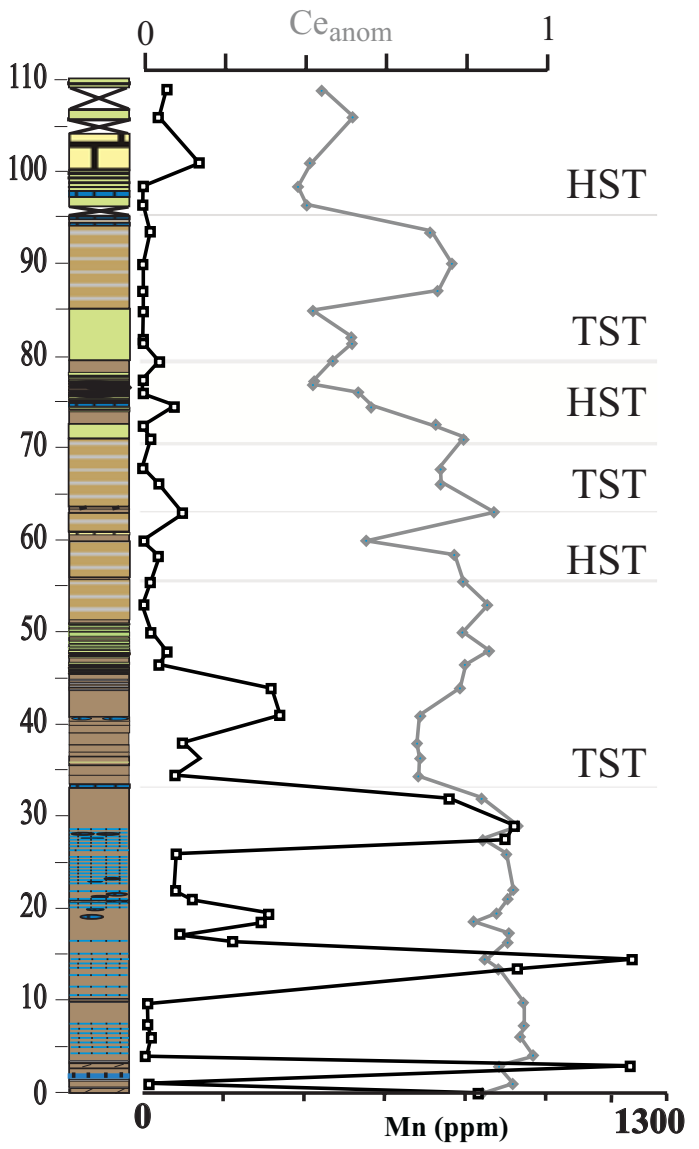

Figure 16. Cerium anomaly ( $\left(e_{\text {anom }}\right)$ and manganese $(\mathrm{Mn})$ trends and sequence stratigraphic subdivisions for the Fire Creek and Tiglukpuk Creek sections. The use of the $\mathrm{Ce}_{\text {anom }}$ as a paleoredox indicator is controversial (see text for discussion) but values greater than -0.1 have been interpreted to indicate anoxia. This leads to the clearly erroneous conclusion that all samples from this study indicate anoxic conditions. Manganese trends appear to be more reliable in terms of interpreting paleoredox conditions with higher Mn values indicating more oxygenated conditions. See figure 11 for key to symbols and patterns. Some thin lithologic units cannot be illustrated at this scale. 
laboratory combined with geochemical analyses have led to the identification of 14 lithofacies. Cyclic sea level changes controlled the development of transgressive (indicated by retrogradational facies stacking patterns) and highstand (indicated by progradational facies stacking patterns) systems tracts of three depositional sequences. Lowstand deposits are either uncommon, difficult to distinguish from transgressive facies, or were reworked by subsequent transgression.

Sequence and chemostratigraphic analyses of these rocks indicate variations in paleoredox conditions within each sequence. Diagenesis may have resulted in alteration of some paleoredox indicators, but analysis of several different redox proxies and basin wide patterns of trace-element enrichment imply either similar diagenetic patterns in very different lithofacies or our preferred interpretation of original syndepositional chemostratigraphic variations. The dominant trend is one of development of low oxygen and potentially anoxic marine bottom waters during early transgression and more oxygenated conditions during late transgression and early highstand. We interpret these trends to indicate the presence of a well-developed OMZ that migrated landward (and possibly dissipated) during transgression and was subsequently forced seaward (or re-established) during highstand as sediment progradation took place (Erbacher et al., 1996; Hoppie and Garrison, 2001; Reichart et al., 2002). OMZ development is directly related to enhanced biological productivity, the oxidation of abundant organic matter, and eventual depletion of oxygen in underlying
A.

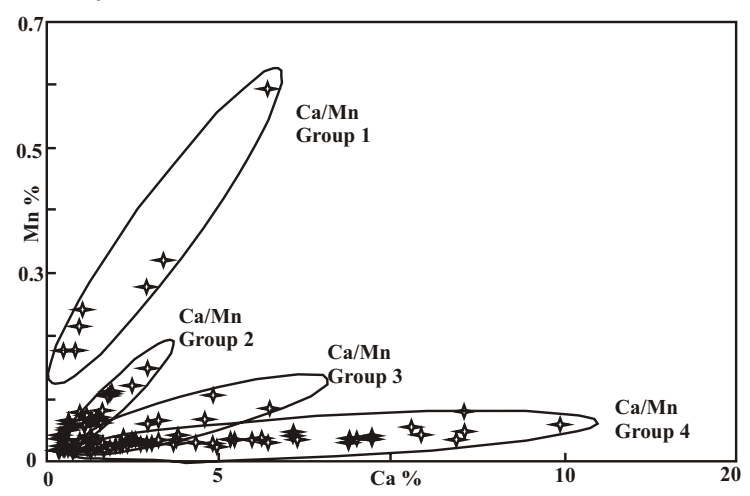

C.

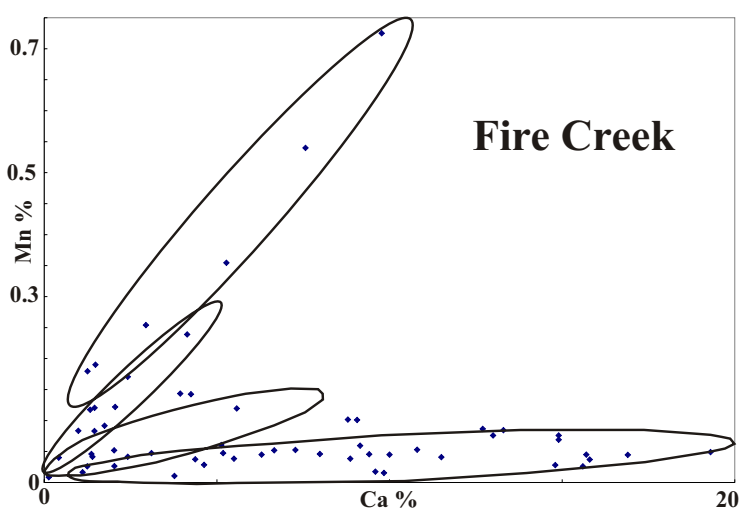

B.

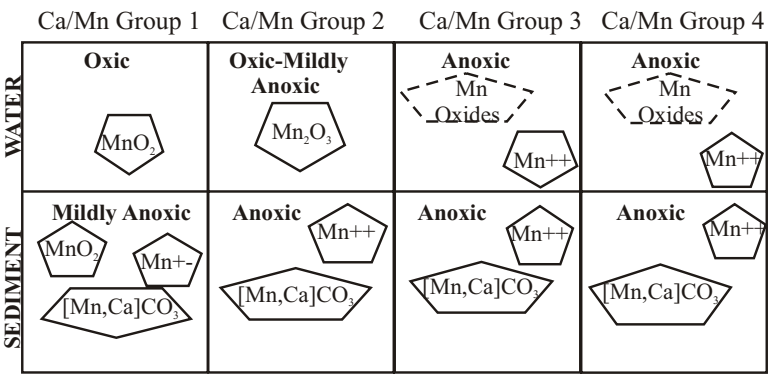

D.

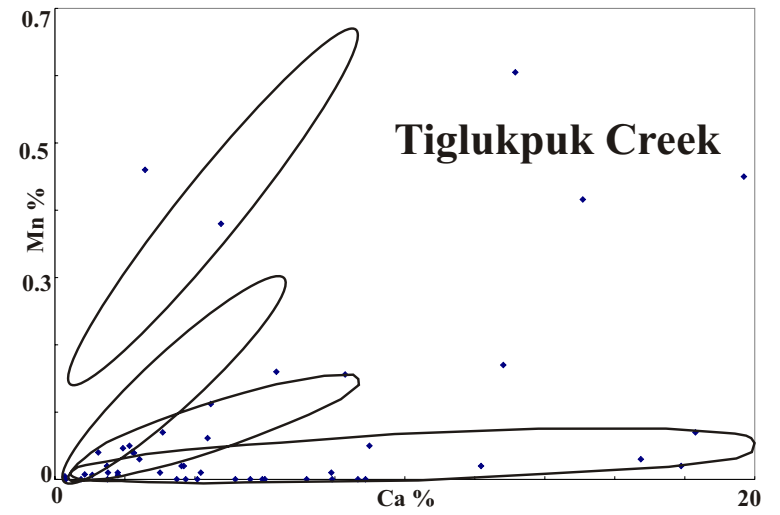

Figure 17.

A. Plot of calcium (Ca) vs. manganese (Mn) concentration for 118 Paleozoic and Mesozoic calcic (>0.4 percent) black shales and groupings related to paleoredox conditions. A higher Ca/Mn ratio (Group 1) indicates oxygenated conditions, while a lower Ca/Mn ratio indicates anoxic conditions (Groups 3, 4). Modified from Quinby-Hunt and Wilde (1996).

B. Different groupings reflect the stability of Mn and Ca minerals in bottom water and interstitial pore water under varying redox conditions. Modified from Quinby-Hunt and Wilde (1996).

C. Scatter plot of Ca/Mn ratios for the Fire Creek section illustrating two distinct groups corresponding to oxic (Group 1) and anoxic conditions (Groups 3, 4) with a few samples plotting in transitional Group 2.

D. Scatter plot of Ca/Mn ratios for the Tiglukpuk Creek section illustrates a well defined grouping indicating anoxic conditions but the rest of the values display considerable scatter. 


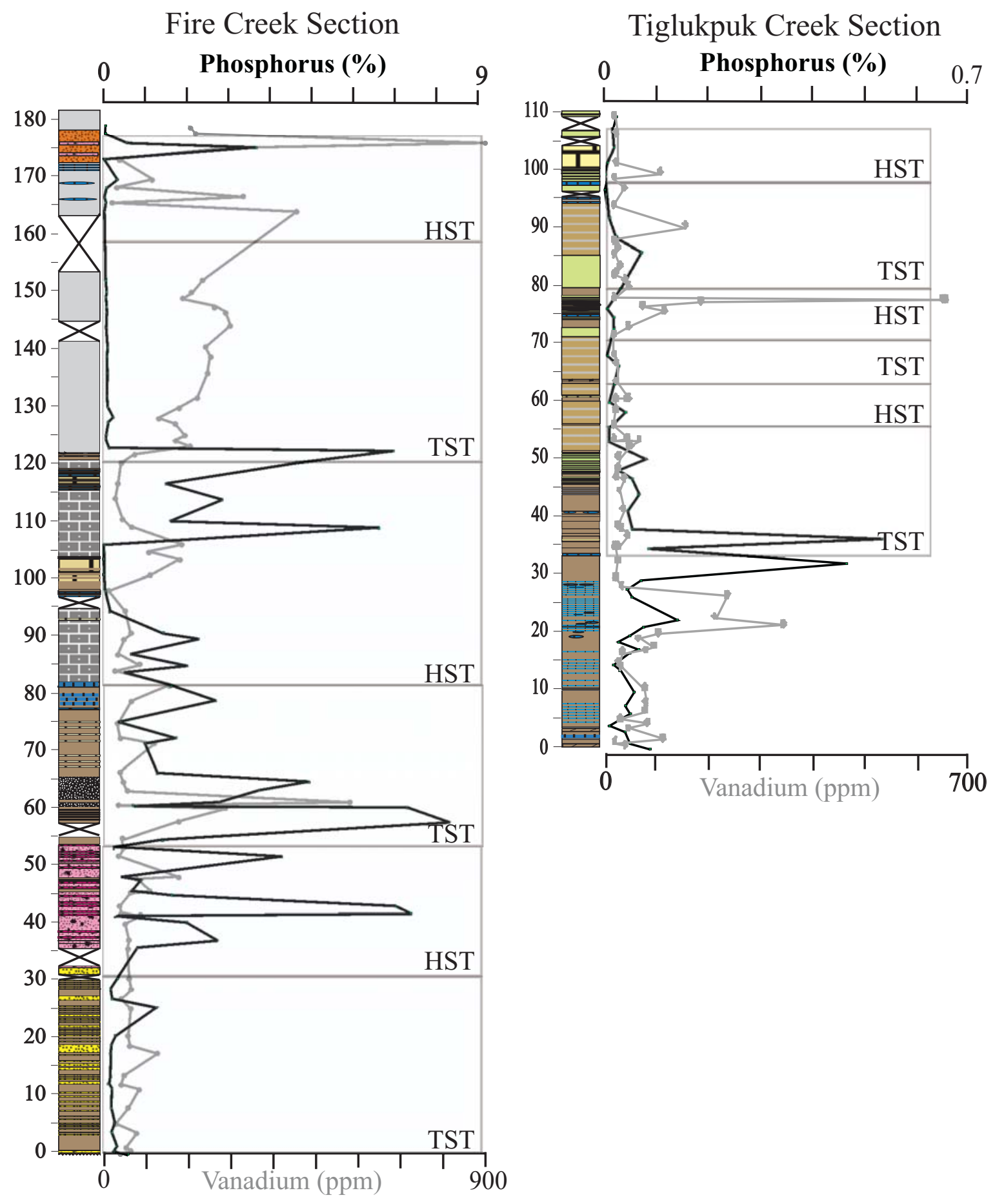

Figure 18. Phosphorus and vanadium trends for the Fire Creek and Tiglukpuk Creek sections. Higher values for each of the phosphorus and vanadium concentrations generally indicate low oxygen environments of deposition. Vanadium values that are higher than phosphorus indicate more dysoxic to anoxic conditions. See figure 11 for key to symbols and patterns. Some thin lithologic units cannot be illustrated at this scale. 


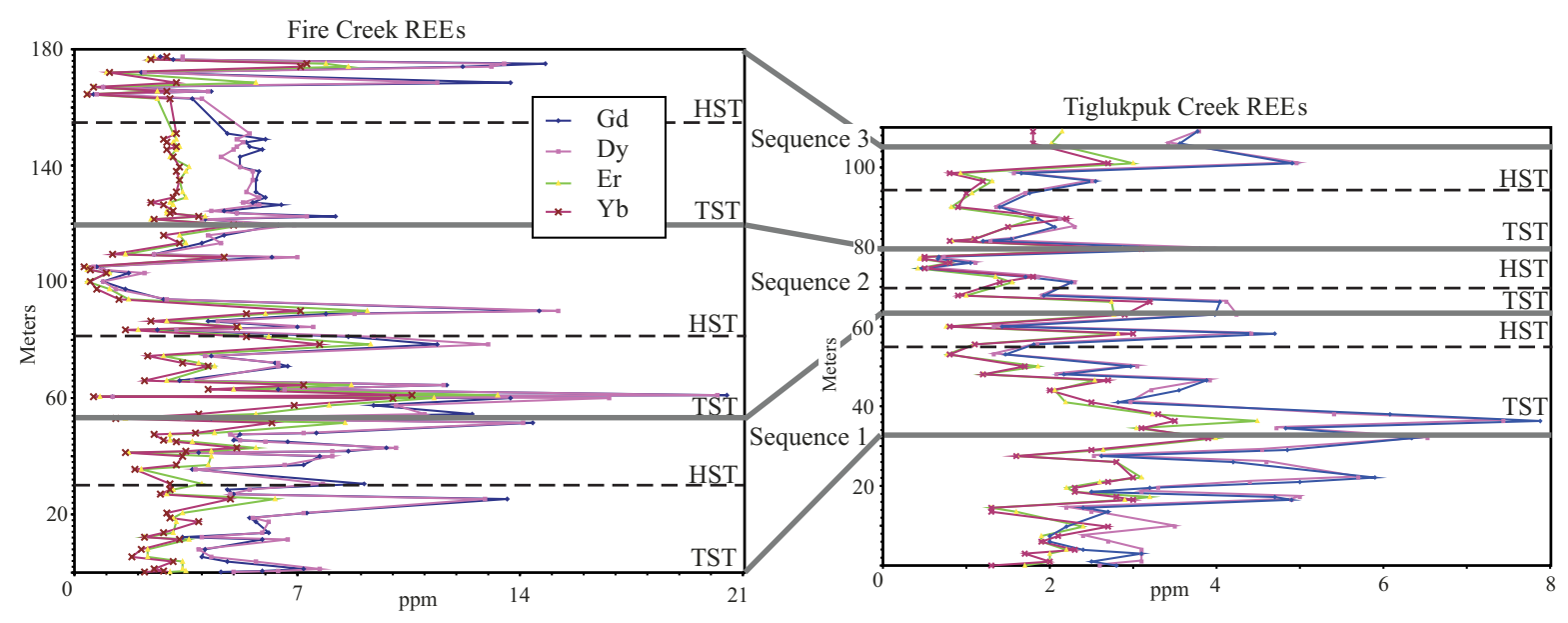

Figure 19. Stratigraphic distribution of the rare earth elements gadolinium (Gd), dysprosium (Dy), erbium (Er), and ytterbium $(\mathrm{Yb})$ in the Fire Creek and Tiglukpuk Creek sections. Note the similarity in pattern between the widely spaced sections implying that values have either not been diagenetically altered or have been altered similarly across the basin.

mid-shelf bottom waters. Enhanced productivity during the Triassic is commonly attributed to upwelling or nutrient-rich waters but the sequence stratigraphic position of proxies for anoxia suggests that enhanced productivity could be related to increased input of nutrients from terrestrial sources during late highstand when fluvial and marginal marine environments had prograded the furthest seaward or during early transgressive reworking of these sediments.

Sea level changes and fluctuating oceanic conditions resulted in heterogeneous vertical facies stacking patterns. Parrish (1987) and Parrish et al. (2001a, b) suggest that the facies successions within the Shublik Formation were a result of minor eustatic sea level variations and processes related to oceanic upwelling conditions (fig. 20). Robison et al. (1996) concluded that such frequent changes in lithology could also be related to changes in climate and water chemistry.

The Shublik Formation displays very similar lithologic and geochemical characteristics to the Phosphoria Formation and was likely deposited under similar oceanographic conditions including a marine upwelling center (fig. 20; McKelvey et al., 1959; Claypool et al., 1978; Parrish, 1982; Whalen, 1996; Piper, 2001; Piper and Link, 2002; Hiatt and Budd, 2003). The accumulation of trace elements in above normal concentrations is generally facilitated by low sedimentation rates (Loutit et al., 1988) and a reducing environment below the sediment-water interface (Quinby-Hunt and Wilde, 1996; Piper and Link, 2002; Algeo and Maynard, 2004). Lowoxygen environments appear to have influenced the accumulation of phosphatic and organic-rich facies especially in the Shublik Formation and likely contributed to the preservation of some organic-rich Otuk Formation facies.
An additional control on paleoredox conditions relates to the degree of marine biologic productivity. High marine productivity, facilitated by upwelling of nutrient-rich water into the photic zone, can create low-oxygen conditions within marine bottom or pore water through oxidation of organic matter, even during periods of accelerated sediment accumulation (Demaison and Moore, 1980; Schuffert et al., 1994). Oxidation of organic matter below the sediment-water interface releases iron and phosphate into the pore water and creates an anoxic environment favorable to the precipitation of phosphates and pyrite (Froelich et al., 1988). This study and the work of others demonstrate that the Shublik and Otuk Formations display high TOC and trace-element contents over a very large area (Parrish, 1987; Robison et al., 1996, Parrish et al., 2001a, b). The highest TOC values are within TSTs but significantly high TOC contents are documented within HSTs as well (fig. 14).

Current paleogeographic reconstructions for Arctic Alaska in the Early to Late Triassic depict a roughly north-south-oriented passive continental margin, connected to the North American craton, with an open ocean basin to the west (fig. 21; Plafker and Berg, 1994; Lawver et al., 2002). Cold water deposits and fauna were cited as evidence of a relatively high latitude setting $\left(\sim 70^{\circ} \mathrm{N}\right)$ for Triassic Arctic Alaska (Plafker and Berg, 1994). Upwelling of cold water onto the shelf, however, could allow certain cool to cold-water species to thrive at a lower latitude, resulting in misinterpretation of the paleolatitude (Hiatt and Budd, 2003). It is possible that Arctic Alaska was at a significantly lower latitude during the Early to Late Triassic and Lawver et al. (2002) suggested a paleolatitude of about $45^{\circ} \mathrm{N}$ (fig. 21A). A recent biostratigraphic study by Mickey et al. (2002) suggests that Point Barrow on the North Slope was juxtaposed with 

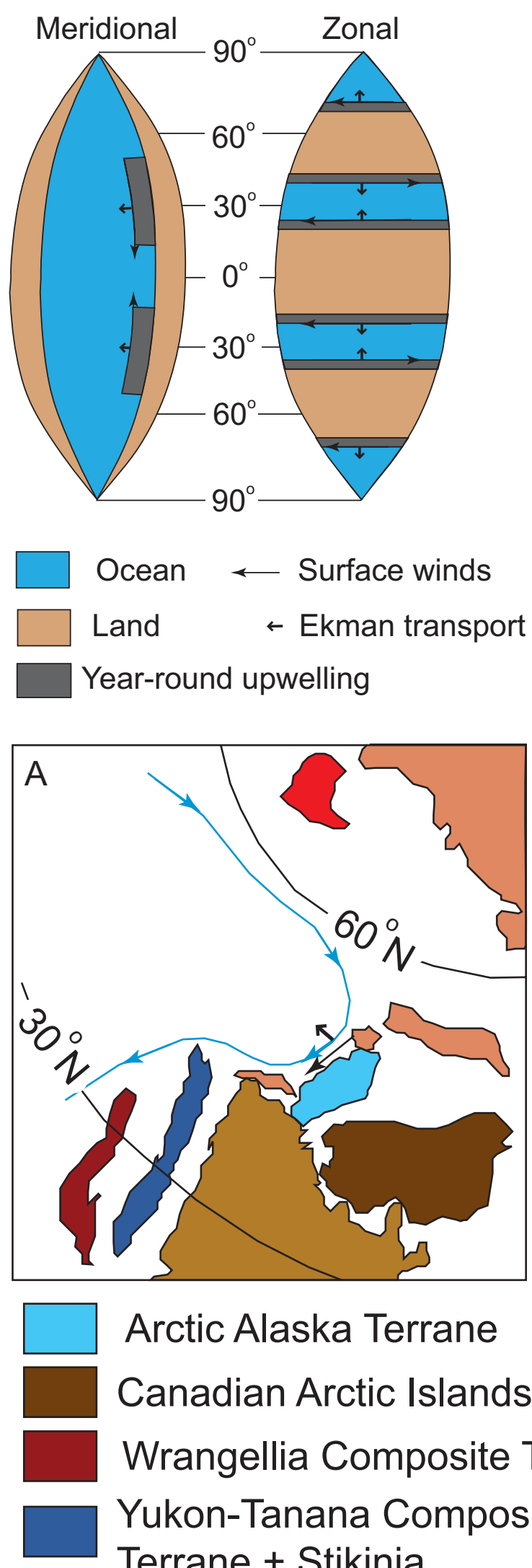

Arctic Alaska Terrane

Canadian Arctic Islands Wrangellia Composite Terrane Yukon-Tanana Composite Terrane + Stikinia $\longleftarrow$ Ocean surface currents
Figure 20 (left). Schematic diagram depicting coastal upwelling models applicable to northern Alaska during the Triassic.

A. Meridional upwelling is driven by shore-parallel winds and associated Ekman transport near subtropical high-pressure cells in eastern ocean basin settings.

B. Zonal upwelling is driven by zonal winds and associated Ekman transport and occurs at the junctures between different atmospheric circulation cells (after Parrish, 1982).

Figure 21 (below). Paleogeographic and paleoceanographic reconstructions for the Late Triassic depicting potential models for marine coastal upwelling.

A. Meridional upwelling driven by northerly winds and Ekman transport in an eastern ocean basin setting.

B. Zonal upwelling driven by polar easterly winds and Ekman transport. Note that this model would require a higher latitude paleogeographic setting and a more east-west-oriented shoreline for Arctic Alaska compared to the meridional upwelling model. Paleogeographic reconstruction after Lawver et al. (2002).

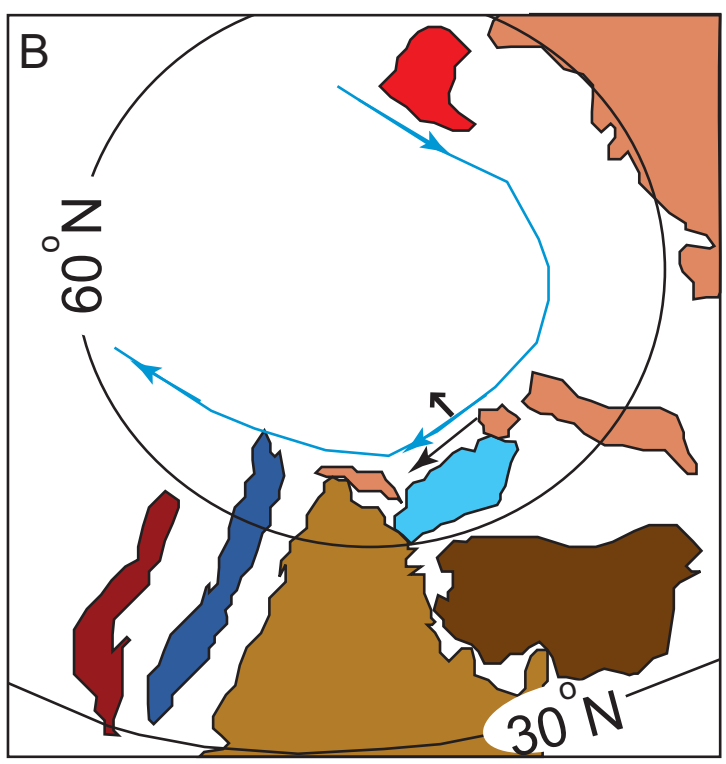

Eurasia

North America

Omolon Massif

$\longleftarrow$ Surface winds

$\leftarrow$ Ekman Transport 
Prince Patrick Island, Canada, although Cecile et al. (1999) argue that the rotational model and connection of Arctic Alaska with the Canadian Arctic Islands during the Triassic was unlikely. Regardless of the tectonic model, if Arctic Alaska were situated with a roughly north-south-oriented passive margin, this setting would readily facilitate meridional oceanic upwelling (figs. 20, 21A) and result in deposition of the glauconitic, phosphatic, and organic-rich facies observed in the Shublik and Otuk Formations (Parrish, 1982).

Alternative explanations for the upwelling deposits of the Shublik and Otuk Formations include a continental margin that was oriented in an east-west configuration or that the deposit is an open-ocean upwelling deposit. Zonal upwelling (on east-west-oriented continental margins) occurs on north- or south-facing coastlines that are oriented at the proper latitude relative to the major zonal wind systems to induce Ekman transport of water offshore (fig. 20; Parrish, 1982). For this type of zonal upwelling to have operated in northern Alaska, significantly more clockwise rotation of Arctic Alaska would be necessary than is called for in the currently accepted tectonic model (Lawver and Scotese, 1990; Mickey et al., 2002). Open-ocean upwelling occurs when there is a wind-induced divergence of ocean surface waters that must be replaced by upwelled, nutrient-rich bottom water (Parrish, 1982). Open-ocean upwelling does not appear to induce sufficient biological productivity to form petroleum source rocks (Parrish, 1982). Stratigraphic analyses indicating shelf environments of deposition also eliminate open-ocean upwelling as a potential model for the Shublik and Otuk Formations (Hulm, 1999; this study).

A synthesis of all the data gathered for this project has resulted in new insights into the sequence stratigraphy, paleoceanography, and paleogeography of upper Lower to Upper Triassic sedimentary rocks along the Brooks Range front and across the North Slope. These data allow the outcrop units in the northeastern Brooks Range to be correlated in detail with the equivalent subsurface units, as well as with equivalent units of the Otuk Formation that crop out in the central Brooks Range.

\section{CONCLUSIONS}

Lithologic, biostratigraphic, gamma ray profile, and chemostratigraphic correlation, including total organic carbon (TOC), major element, rare earth element (REE), and trace-metal analyses, were all utilized to create a high-resolution sequence stratigraphic model and to make interpretations about the depositional history, paleogeography, and paleoceanography of the Triassic rock units under investigation. Fourteen lithofacies are identified for the Fire Creek and Tiglukpuk Creek sections, and facies stacking patterns display evidence for episodes of progradation and retrogradation and changing paleoredox conditions in the upper Lower to Upper Triassic strata. Sequence boundaries are defined by erosional truncation, abrupt facies changes, or changes in facies stacking patterns related to relative sea level change.

The Fire Creek Siltstone, Shublik Formation, and Karen Creek Sandstone and the laterally equivalent portions of the Otuk Formation can be divided into three third-order depositional sequences based on identification of major flooding surfaces and facies stacking patterns. These sequences can be correlated from the subsurface near Prudhoe Bay to the northeastern and central Brooks Range. Sequences are composed of systems tracts that are in turn made up of flooding-surface-bounded parasequences or shallowing-upward cycles or non-cyclic intervals that were likely deposited deep enough to have been unaffected by relative sea level change. Parasequences within the Shublik Formation generally shoal upward from organic-rich shales or fine-grained siltstones through sandy phosphorites or phosphatic wacke/packstones to limestones. Otuk parasequences begin with shale, organic-rich shale, or cherty lithologies, and shoal upward through porcelanite, siltstone, and/or argillaceous/silty limestone or wacke/packstone facies.

Geochemical analyses, both organic and inorganic, of these rock units provide clues to their depositional history, patterns of source rock deposition, paleoredox conditions, and the paleoceanography of the Middle to Late Triassic. The geochemical signature of the Shublik and Otuk Formations indicate that those rocks were deposited in an environment characterized by fluctuating oxygenation. Both organic and inorganic geochemical data allow us to interpret paleoredox gradients.

Organic geochemical analyses for the Shublik and Otuk Formations indicate that the most organic-rich facies in the Otuk Formation (Tiglukpuk Creek and Atigun Gorge sections) occur in porcelanite and shale facies. The most organic-rich facies in the Shublik Formation (Fire Creek section) are within shale and siltstone that is interbedded with calcareous facies, and phosphatic wacke/packstone facies. TOC values are highest in facies interpreted as being deposited in transgressive low-oxygen environments. Organic matter in the Shublik Formation is of both terrestrial and marine origin. Much is thermally altered beyond recognition but terrestrial material includes small structured phytoclasts such as wood, cuticle, or vascular leaf or stem fragments. Pollen and spores were rare but spores from sphagnum moss, sphenopsids, and monosulcate pollen indicative of cycads and/or ginkgos were identified. This suggests that terrestrial organics were delivered to the basin through terrestrial runoff as no wind-transported pollen grains were discovered. Marine organic matter consists of algal matter, acritarchs, and possibly dinoflagellate cysts, 
but much of the preserved kerogen was indeterminate due to alteration.

$\mathrm{VR}_{\mathrm{o}}$ values for the Tiglukpuk Creek section indicate that those rocks are just within the wet gas phase of hydrocarbon generation. Rock-eval and vitrinite reflectance analyses provide data that indicate the Shublik and Otuk Formations are mature to over mature in the central and northeast Brooks Range. Inorganic geochemical signatures also support the interpretation of varying paleoredox conditions. The manganese, phosphorus, vanadium, and TOC values indicate dominantly oxic bottom waters during deposition of the Fire Creek Siltstone and upper shale member of the Otuk Formation and more fluctuating redox conditions during deposition of the Shublik Formation and the remainder of the Otuk Formation. Chemostratigraphic analyses demonstrate that oxygen contents were lower during transgressive events and generally higher at times of sea level highstand, although highstand facies locally display evidence of more reducing conditions. This pattern is also evident in the distribution of the phosphate-rich rock units that lie dominantly within HSTs deposited in middle to inner shelf environments. Organic-rich units in the Shublik Formation tend to underlie or occur at the base of phosphaterich units (figs. 14, 18), implying that oxygenation generally increased as deposition shifted from organicrich to phosphatic lithofacies.

Long-term trends in paleoredox conditions and the distribution of the various upwelling-related facies indicate that the OMZ migrated updip with transgression and downdip during regression. This is interpreted to indicate the transit of the upwelling zone perpendicular to the continental margin during relative sea level rise and fall. Modern zones of well-developed oceanic upwelling occur in geographic regions with strikingly similar characteristics. Ancient upwelling deposits, like the Permian Phosphoria Formation, have commonly been explained based on observations and/or models of modern upwelling zones (Parrish, 1982; Whalen, 1995; Piper and Link, 2002). New evidence is mounting that some ancient upwelling deposits may have formed in environments much different from those in modern oceans (Hiatt and Budd, 2003). Phosphatic sediments of the Shublik and Phosphoria Formations were deposited during a first order (200-400 million year cycle) eustatic sea level lowstand (Vail et al., 1977; Haq et al., 1988). Deposition of these formations did, however, take place during second order (10-100 million year cycle) eustatic sea level highs and this study illustrates that phosphatic sediments of the Shublik Formation were preferentially deposited during high-frequency second or third order sea level highstands.

Paleogeography must be taken into account when making interpretations about ancient oceanic upwelling deposits. Upwelling most commonly occurs on north- south-oriented western continental margins (eastern ocean basins), with predominant northerly along-shore winds in the northern hemisphere and predominant southerly along-shore winds in the southern hemisphere (fig. 20; Baturin, 1982; Parrish, 1982; Notholt and Jarvis, 1990; Föllmi et al., 1991; Whalen, 1995). Upwelling was likely influenced by seasonal changes in temperature and air circulation patterns as well as variation in regional climatic conditions (Hiatt and Budd, 2003). Although there are several different ways in which upwelling can occur, most of the evidence indicates that a north-south-oriented continental margin upwelling zone existed during deposition of upper Lower to Upper Triassic sedimentary rocks of northern Alaska (fig. A; Parrish et al., 2001a, b; this study). The results of this study, while consistent with, do not necessarily provide additional support for the rotational translation of Arctic Alaska from a position near the Canadian Arctic Islands (Lawver and Scotese, 1990; Mickey et al., 2002).

Basin-wide changes in water chemistry are recorded by minor, immobile elements and supplement the correlations made based on facies stacking patterns. The interplay of different orders of sea level change (third order depositional sequences and higher frequency parasequence sets that make up systems tracts) and upwelling dynamics make for a complex assemblage of facies and facies stacking patterns typical of upwelling deposits.

Widely distributed facies across the study area indicate that the continental margin was extremely broad and very gently sloping. Sequence and chemo-stratigraphic analysis of these rocks suggest that deposition took place on a low-angle shelf under fluctuating paleoceanographic conditions and low rates of siliciclastic sediment deposition (Dingus, 1984; Parrish, 1987; Robison et al., 1996; Hulm, 1999; Parrish et al., 2001a, b; and this study). The deposition of organic-rich, cherty, and phosphatic facies at the end of the Middle Triassic is evidence for the birth of an ancient oceanic upwelling zone, which persisted through much of the Upper Triassic. The lack of upwelling-related facies in overlying lower Jurassic rocks indicates that the ancient upwelling zone died out, thus recording a complete cycle from initiation to collapse of an oceanic upwelling system.

\section{ACKNOWLEDGMENTS}

This research could not have been completed without the generous support of the Alaska Department of Natural Resources Division of Geological \& Geophysical Surveys (DGGS). DGGS provided monetary and field logistical support as well as several Rock-eval analyses. Thanks to Ken Bird, project chief, U.S. Geological Survey Alaska Energy Resources Project, for providing funding for inorganic geochemical analyses and for encouraging us to undertake the project. We also thank the University of Alaska Fairbanks for a Natural 
Resources Grant that partially funded this research and the Department of Geology and Geophysics for assisting with the cost of manuscript preparation. Rainer Newberry, UAF, derserves thanks for assisting with interpretation of inorganic geochemical data. Thanks to Julie Dumoulin, USGS, and Erik Hulm, BP, for thoughtful reviews that helped to improve the manuscript. Thanks are also in order to the Nunamiut Corporation for permitting access to outcrops on their land in the north-central Brooks Range and to the Department of Interior for permission to work in the Arctic National Wildlife Refuge.

\section{REFERENCES CITED}

Algeo, T.J., and Maynard, J.B., 2004, Trace-element behavior and redox facies in core shales of Upper Pennsylvanian Kansas-type cyclothems: Chemical Geology, v. 206, no. 3-4, p. 289-318.

Barnes, D.A., 1987, Reservoir quality in the Sag River Formation, Prudhoe Bay Field, Alaska, in Tailleur, I.L., and Weimer, P., eds., Alaskan North Slope geology: Field Trip Guidebook, Pacific Section SEPM and Alaska Geological Society, v. 50, p. 85-94.

2001, Sedimentology and stratigraphy of the Sag River Formation, Northern NPR, Alaska, in Houseknecht, D.W., ed., Petroleum Plays and Systems in the National Petroleum Reserve-Alaska: SEPM (Society for Sedimentary Geology) Core Workshop No. 21, p. 215-230.

Baturin, G.N., 2000, Formation and evolution of phosphorite grains and nodules on the Namibian Shelf, from Recent to Pleistocene, in Glenn, C.R., PrevotLucas, L., and Lucas, J., eds., Marine Authigenesis: From Global to Microbial: SEPM Special Publication No. 66, p. 185-199.

Baturin, G.N., and Vitaliano, D.B., 1982, Phosphorites on the Sea Floor; Origin, Composition and Distribution: Amsterdam, Netherlands, Elsevier Scientific Publishing Co., 343 p.

Bird, K.J., 1985, The framework geology of the North Slope of Alaska as related to oil-source rock correlations, in Magoon, L.B., and Claypool, G.E., eds., Alaska North Slope oil-rock correlation study-analysis of North Slope crude: AAPG Studies in Geology, v. 20, p. 3-29.

1994, Ellesmerian petroleum system, North Slope, Alaska, U.S.A., in Magoon, L.B., and Dow, W.G., eds., The petroleum system; from source to trap: AAPG Memoir 60, p. 339-358.

Bird, K.J., and Molenaar, C.M., 1987, Stratigraphy, Ch. 5 in Bird, K.J., and Magoon, L.B., eds., Petroleum geology of the northern part of the Arctic National Wildlife Refuge, northeastern Alaska: U.S. Geological Survey Bulletin 1778, p. 37-59.
Blodgett, R.B. and Bird, K.J., 2002, Megafossil biostratigraphy and T-R cycles of the Shublik Formation in the Phoenix well, Northern Alaska, AAPG Pacific Section and SPE Western Region joint conference: Energy frontiers; a 2002 perspective; abstracts, AAPG Bulletin, v. 86, no. 6, p. 1137.

Bodnar, D.A., 1984, Stratigraphy, age, depositional environments, and hydrocarbon source rock evaluation of the Otuk Formation, north-central Brooks Range, Alaska: Fairbanks, Alaska, University of Alaska Fairbanks Master's Thesis, 232 p.

1989, Stratigraphy of the Otuk Formation and a Cretaceous coquinoid limestone and shale unit, northcentral Brooks Range, in Mull, C.G., and Adams, K.E., eds., Dalton Highway, Yukon River to Prudhoe Bay, Alaska: Alaska Division of Geological \& Geophysical Surveys Guidebook 7, v. 2, p. 277-284.

Breit, G.N., and Wanty, R.B., 1991, Vanadium accumulation in carbonaceous rocks; a review of geochemical controls during deposition and diagenesis: Chemical Geology, v. 91, no. 2, p. 83-97.

Brosgé, W.P., Dutro, J.T., Mangus, M.D., and Reiser, H.N., 1962, Paleozoic sequence in the eastern Brooks Range, Alaska: AAPG Bulletin, v. 46, no. 12, p. 21742198.

Burchette, T.P., and Wright, V.P., 1992, Carbonate ramp depositional systems: Sedimentary Geology, v. 79, no. 1-4, p. 3-57.

Cecile M.P., Lane, L.S., Khudoley, A.K., and Kos'ko, M.K., 1999, Lower Paleozoic rocks around today's Arctic Ocean; Two ancestral continents and associated plates; Alaskan rotation unnecessary and unlikely: Polarforschung, v. 69, p. 235-241.

Cheel, R.J., 1991, Grain fabric in hummocky cross-stratified storm beds; genetic implications: Journal of Sedimentary Petrology, v. 61, no. 1, p. 102-110.

Claypool, G.E., Love, A.H., and Maughan, E.K., 1978, Organic geochemistry, incipient metamorphism, and oil generation in black shale members of Phosphoria Formation, western interior, United States: AAPG Bulletin, v. 62, no. 1, p. 98-120.

Collinson, J.D., 1969, The sedimentology of the Grindslow Shales and the Kinderscout Grit; a deltaic complex in the Namurian of northern England: Journal of Sedimentary Petrology, v. 39, no. 1, p. 194-221.

Condie, K.C., 1991, Another look at rare earth elements in shales: Geochimica et Cosmochimica Acta, v. 55, no. 9, p. 2527-2531.

Crowder, R.K., 1990, Permian and Triassic sedimentation in the northeastern Brooks Range, Alaska; deposition of the Sadlerochit Group: AAPG Bulletin, v. 74, no. 9, p. 1351-1370. 
Curiale, J.A., 1987, Distribution and occurrences of metals in heavy crude oils and solid bitumenimplications for petroleum exploration, in Meyer, R.F., ed., Exploration of Heavy Crude Oil and Natural Bitumen: AAPG Studies in Geology, v. 25, p. 207-219.

Davranche, M., Pourret, O., Gruau, G., Dia, A., and Le Coz-Bouhnik, M., 2005, Adsorption of REE(III)humate complexes onto $\mathrm{MnO}_{2}$; Experimental evidence for cerium anomaly and lanthanide tetrad effect suppression: Geochimica et Cosmochimica Acta, v. 69, p. 4825-4835.

de Graciansky, P., Hardenbol, J., Jacquin, T., and Vail, P.R., eds., 1998, Mesozoic and Cenozoic sequence stratigraphy of European basins: SEPM Special Publication 60, 786 p.

Demaison, G.J., and Moore, G.T., 1980, Anoxic environments and oil source bed genesis: AAPG Bulletin, v. 64, no. 8, p. 1179-1209.

Detterman, R.L., 1970, Analysis of Shublik Formation rocks from Mt. Michelson quadrangle, Alaska: U.S. Geological Survey Open-File Report 70-101, 1 p., 3 sheets.

Detterman, R.L., Reiser, H.N., Brosgé, W.P., and Dutro, J.T., Jr., 1975, Post-Carboniferous stratigraphy, northeastern Alaska: U.S. Geological Survey Professional Paper 886, 46 p.

Dingus, A.S., 1984, Paleoenvironmental reconstruction of the Shublik Formation on the North Slope of Alaska: Berkeley, California, University of California Master's Thesis, $108 \mathrm{p}$.

Dorning, K.J., 1986, Organic microfossil geothermal alteration and interpretation of regional tectonic provinces: Journal of the Geological Society of London, v. 143 , no. 1, p. 219-220.

Droser, M.L., and Bottjer, D.J., 1986, A semiquantitative field classification of ichnofabric: Journal of Sedimentary Petrology, v. 56, no. 4, p.558-559.

Duke, W.L., Arnott, R.W.C., and Cheel, R.J., 1991, Shelf sandstones and hummocky cross-stratification; New insights on a stormy debate: Geology, v. 19, no. 6, p. 625-628.

Dunham, R.J., 1962, Classification of carbonate rocks according to depositional texture, in Ham, W.E., ed., Classification of carbonate rocks-A symposium: AAPG Memoir 1, p. 108-121.

Ekdale, A.A., Bromley, R.G., and Pemberton, S.G., 1984, Ichnology: the use of trace fossils in sedimentology and stratigraphy: SEPM Short Course Notes, v. 15, $317 \mathrm{p}$.

Elderfield, H., and Greaves, M.J., 1982, The rare earth elements in seawater: Nature, v. 296, no. 5854, p. 214-219.
Embry, A.F., 1988, Triassic sea-level changes; evidence from the Canadian Arctic Archipelago, in Wilgus, C.K., Hastings, B.S., Ross, C.A., Posamentier, H., Van Wagoner, J., and Kendall, C.G.St.C., eds., Sealevel Changes; an Integrated Approach: Tulsa, Oklahoma, SEPM Special Publication, v. 42, p. 249-259.

Embry, A.F., III, and Klovan, J.E., 1972, Absolute water depth limits of Late Devonian paleoecological zones: Geologische Rundschau, v. 61, no. 2, p. 672-686.

Erbacher, J., Thurow, J., and Littke, R., 1996, Evolution patterns of radiolaria and organic matter variations; a new approach to identify sea-level changes in MidCretaceous pelagic environments: Geology, v. 24, no. 6, p. 499-502.

Föllmi, K.B., 1990, Condensation and phosphogenesis; Example of the Helvetic mid-Cretaceous, in Notholt, A.J.G., and Jarvis, I., eds., Phosphorite Research and Development: Geological Society Special Publication no. 52, p. 237-252.

Föllmi, K.B., Garrison, R.E., and Grimm, K.A., 1991, Stratification in phosphatic sediments: Illustrations from the Neogene of California, in Einsele, G., Ricken, W., and Seilacher, A., eds., Cycles and Events in Stratigraphy: Berlin, Springer-Verlag, p. 493-507.

Froelich, P.N., Arthur, M.A., Burnett, W.C., Deakin, M., Hensley, V., Jahnke, R., Kaul, L., Kim, K.H., Roe, K., Soutar, A., and Vathakanon, C., 1988, Early diagenesis of organic matter in Peru continental margin sediments; phosphorite precipitation, in Burnett, W.C., and Froelich, P.N., eds., The origin of marine phosphorite; the results of the R.V. Robert D. Conrad Cruise 23-06 to the Peru shelf: Marine Geology, v. 80, p. 309-343.

German, C.R., and Elderfield, H., 1990, Application of the Ce anomaly as a paleoredox indicator; the ground rules: Paleoceanography, v. 5, no. 5, p. 823-833.

Goldberg, E.D., Koide, M., Schmitt, R.A., and Smith, R.H., 1963, Rare earth distributions in the marine environment: Journal of Geophysical Research, v. 68, no. 14 , p. 4209-4217.

Goldhammer, R.K., Dunn, P.A., and Hardie, L.A., 1987, High-frequency glacio-eustatic oscillations with Milankovitch characteristics recorded in northern Italy: American Journal of Science, v. 287, no. 9, p. 853-892.

Gradstein, F.M., and Ogg, J.G., 2004, Geologic Time Scale 2004-Why, how, and where next!: Lethaia, v. 37, no. 2, p. 175-181.

Grantz, A., May, S.D., and Hart, P.E., 1994, Geology of the arctic continental margin of Alaska, in Plafker, G. and Berg, H.C., eds., The geology of Alaska: Boulder, Colorado, Geological Society of America, The Geology of North America, v. G-1, p. 17-48. 
Halgedahl, S.L., and Jarrard, R.D., 1987, Paleomagnetism of the Kuparuk River Formation from oriented drill core; evidence for rotation of the North Slope block, in Tailleur, I.L., and Weimer, P., eds., Alaskan North Slope Geology: SEPM Pacific Section and Alaska Geological Society, v. 50, p. 581617.

Haq, B.U., Hardenbol, J., and Vail, P.R., 1988, Mesozoic and Cenozoic chronostratigraphy and eustatic cycles, in Wilgus, C.K., Hastings, B.S., Ross, C.A., Posamentier, H.W., Van Wagoner, J., and Kendall, C.G. St. C., eds., Sea-level changes; An integrated approach: SEPM Special Publication 42, p. 72-108.

Harris, P.M., Saller, A.H., and Simo, J.A., eds., 1999, Advances in carbonate sequence stratigraphy; Application to reservoirs, outcrops, and models: SEPM special publication 63, $421 \mathrm{p}$.

Hiatt, E.E., and Budd, D.A., 2003, Extreme paleoceanographic conditions in a Paleozoic oceanic upwelling system; Organic productivity and widespread phosphogenesis in the Permian Phosphoria Sea, in Chan, M.A., and Archer, A.W., eds., Extreme depositional environments; Mega end members in geologic time: Geological Society of America Special Paper 370, p. 245-264.

Holser, W.T., 1997, Evaluation of the application of rareearth elements to paleoceanography, Palaeogeography, Paleoclimatology, Palaeoecology, v. 132, no. 1-4, p. 309-323.

Hoppie, B., and Garrison, R.E., 2001, Miocene phosphate accumulation in the Cuyama Basin, southern California: Marine Geology, v. 177, no. 3-4, p. 353380.

Hubbard, R.J., Edrich, S.P., and Rattey, R.P., 1987, Geologic evolution and hydrocarbon habitat of the 'Arctic Alaska microplate’: Marine and Petroleum Geology, v. 4, no. 1, p. 2-34.

Hughes, W.B., Holba, A.G., and Miller, D.E., 1985, North Slope Alaska oil-rock correlation study, in Magoon, L.B., and Claypool, G.E., eds., Alaska North Slope oil-rock correlation study; analysis of North Slope crude: AAPG Studies in Geology, no. 20, p. 379402.

Hulm, E.J., 1999, Subsurface facies architecture and sequence stratigraphy of the Eileen Sandstone, Shublik Formation, and Sag River Sandstone, Arctic Alaska: Fairbanks, Alaska, University of Alaska Fairbanks Master's Thesis, 98 p.

Jones, D.L., and Murchey, B.L., 1986, Geologic significance of Paleozoic and Mesozoic radiolarian chert: Annual Review of Earth and Planetary Sciences, v. 14, p. 455-492.

Jones, H.P., and Speers, R.G., 1976, Permo-Triassic reservoirs of Prudhoe Bay field, North Slope, Alaska, in Braunstein, J., ed., North American Oil and Gas Fields: AAPG Memoir 24, p. 23-50.

Kelley, J.S., and Brosgé, W.P., 1995, Geologic framework of a transect of the central Brooks Range; regional relations and an alternative to the Endicott Mountains allochthon: American Association of Petroleum Geologists Bulletin 79, no. 8, p. 1087-1116.

Kupecz, J.A., 1995, Depositional setting, sequence stratigraphy, diagenesis, and reservoir potential of a mixed-lithology, upwelling deposit, Upper Triassic Shublik Formation, Prudhoe Bay, Alaska: AAPG Bulletin, v. 79, no. 9, p. 1301-1319.

Lawver, L.A., and Scotese, C.R., 1990, A review of tectonic models for the evolution of the Canadian Basin, in Grantz, A., Johnson, L., and Sweeney, J.F., eds., Geology of North America Volume L, The Arctic Ocean Region: Boulder, Colorado, Geological Society of America, p. 593-618.

Lawver, L.A., Grantz, A., and Gahagan, L.M., 2002, Plate kinematic evolution of the present Arctic region since the Ordovician, in Miller, E.L., Grantz, A., and Klemperer, S.L., eds., Tectonic Evolution of the Bering Shelf-Chukchi Sea-Arctic Margin and Adjacent Landmasses: Geological Society of America Special Paper 360, p. 333-358.

Loucks, R.G., and Sarg, J.F., eds., 1993, Carbonate sequence stratigraphy: recent developments and applications: AAPG memoir 57, 545 p.

Loutit, T.S., Hardenbol, J., Vail, P.R., and Baum, G.R., 1988, Condensed sections; the key to age dating and correlation of continental margin sequences, in Wilgus, C.K., Hastings, B.S., Ross, C.A., Posamentier, H., Van Wagoner, J., Kendall, C.G.St.C., eds., Sea-level changes; an integrated approach: SEPM Special Publication No. 42, p. 183-213.

Magoon, L.B., and Bird, K.J., 1988, Evaluation of petroleum source rocks in the National Petroleum Reserve in Alaska using organic-carbon content, hydrocarbon content, visual kerogen, and vitrinite reflectance data, in Gryc, George, ed., Geology and Exploration of the National Petroleum Reserve in Alaska, 1974-1982: U.S. Geological Survey, Professional Paper 1399, p. 381-450.

McKelvey, V.E., Cheney, T.M., Cressman, E.R., Sheldon, R.P., Swanson, R.W., and Williams, J.S., 1959, The Phosphoria, Park City, and Shedhorn Formations in the Western Phosphate Field: U.S. Geological Survey Professional Paper 313-A, p. 1-47.

McLennan, S.M., 1989, Rare earth elements in sedimentary rocks; Influence of provenance and sedimentary processes, in Lipin, B.R., and McKay, G.A., eds., Geochemistry and mineralogy of rare earth elements: Mineralogical Society of America, Reviews in Mineralogy, v. 21, p. 169-200. 
MacLeod, K.G., and Irving, A.J., 1996, Correlation of cerium anomalies with indicators of paleoenvironment: Journal of Sedimentary Research, v. 66, no. 5, p. 948-988.

McMillen, K.J., and Colvin, M.D., 1987, Facies correlation and basin analysis of the Ivishak Formation, Arctic National Wildlife Refuge, Alaska, in Tailleur, I.L., and Weimer, P., eds., Alaskan North Slope Geology Field Trip Guidebook: Pacific Section, Society of Economic Paleontologists and Mineralogists, v. 50, p. 381-390.

Mickey, M.B., Byrnes, A.P., and Haga, H., 2002, Biostratigraphic evidence for the prerift position of the North Slope, Alaska, and Arctic Islands Canada, and Sinemurian incipient rifting of the Canada Basin, in Miller, E.L., Grantz, A., and Klemperer, S.L., eds., Tectonic evolution of the Bering Shelf-Chukchi SeaArctic margin and adjacent landmasses: Geological Society of America Special Paper 360, p. 67-75.

Molenaar, C.M., Bird, K.J., and Collett, T.S., 1986, Regional correlation sections across the North Slope of Alaska: U.S. Geological Survey Miscellaneous Field Studies Map MF-I 907, 1 sheet.

Moore, T.E., Wallace, W.K., Bird, K.J., Karl, S.M., Mull, C.G., and Dillon, J.T., 1994, Geology of northern Alaska, in Plafker, G. and Berg, H.C., eds., The Geology of Alaska: Boulder, Colorado, Geological Society of America, v. G-1, p. 49-140.

Morford, J.L., and Emerson, S., 1999, The geochemistry of redox sensitive trace metals in sediments: Geochimica et Cosmochimica Acta, v. 63, no. 1112, p. $1735-1750$.

Mozley, P.S. and Hoernle, K., 1990, Geochemistry of carbonate cements in the Sag River and Shublik Formations (Triassic/Jurassic), North Slope Alaska; implications for the geochemical evolution of formation waters: Sedimentology, v. 37, no. 5, p. 817-836.

Mull, C.G., Tailleur, I.L., Mayfield, C.F., Ellersieck, I.F., and Curtis, S., 1982, New upper Paleozoic and lower Mesozoic stratigraphic units, central and western Brooks Range, Alaska: AAPG Bulletin, v. 66, no. 3, p. 348-362.

Mull, C.G., Glenn, R.K., and Adams, K.E., 1987, Tectonic evolution of the central Brooks Range mountain front: Evidence from the Atigun Gorge region: Journal of Geophysical Research, v. 102, no. B9, p. 20,749-20,772.

Newman, G.W., Mull, C.G., and Watkins, N.D., 1979, Northern Alaska paleomagnetism, plate rotation, and tectonics, in Sisson, A., ed., Relationship of plate tectonics to Alaskan geology and resources; Proceedings, Alaska Geological Society Symposium, Anchorage, Alaska, April, 1977: Alaska Geological Society, no. 6, p. C-1 to C-7.
Notholt, A.J.G., and Jarvis, I., eds., 1990, Phosphorite Research and Development: Geological Society Special Publication No. 52, 326 p.

Palmer, A.R., and Geissman, J., 1999, Geologic Time Scale: Geological Society of America, Product code CTS004.

Parrish, J.T., 1982, Upwelling and petroleum source beds, with reference to the Paleozoic: AAPG Bulletin, v. 66, no. 6, p. 750-774.

1987, Lithology, geochemistry, and depositional environment of the Triassic Shublik Formation, northern Alaska, in Tailleur, I.L., and Weimer, P., eds., Alaskan North Slope geology: Field Trip Guidebook - SEPM, Pacific Section, Special Publication 50, p. 391-396.

Parrish, J.T., Droser, M.L., and Bottjer, D.J., 2001a, A Triassic upwelling Zone: the Shublik Formation, Arctic Alaska, U.S.A.: Journal of Sedimentary Research, v. 71, no. 2, p. 272-285.

Parrish, J.T., Whalen, M.T., and Hulm, E.J., 2001b, Shublik Formation lithofacies, environments, and sequence stratigraphy, Arctic Alaska, U.S.A., in Houseknecht, D.W., ed., Petroleum Plays and Systems in the National Petroleum Reserve - Alaska: SEPM (Society for Sedimentary Geology) Core Workshop No. 21, p. 89-110.

Peters, K.E., 1986, Guidelines for evaluating petroleum source rock using programmed pyrolysis: AAPG Bulletin, v. 70, no. 3, p. 318-329.

Pettijohn, F.J., 1975, Sedimentary Rocks, $3^{\text {rd }}$ edition: New York, Harper and Row, 718 p.

Piper, D.Z., 2001, Marine chemistry of the Permian Phosphoria Formation and basin, southeast Idaho, Economic Geology, v. 96, no. 3, p. 599-620.

Piper, D.Z., and Link, P.K., 2002, An upwelling model for the Phosphoria Sea; A Permian, ocean-margin sea in the northwest United States: AAPG Bulletin, v. 86, no. 7, p. 1217-1235.

Plafker, G. and Berg, H.C., 1994, Overview of the geology and tectonic evolution of Alaska, in Plafker, G., and Berg, H.C., eds., The Geology of Alaska: Boulder, Colorado, Geological Society of America, v. G1, p. 989-1021.

Posamentier, H.W., and Allen, G.P. 1999, Siliciclastic sequence stratigraphy-Concepts and applications, in Dalrymple, R.W., ed., Concepts in Sedimentology and Paleontology No. 7: SEPM, p. 191.

Quinby-Hunt, M.S., and Wilde, P., 1996, Chemical depositional environments of calcic marine black shales: Economic Geology, v. 91, no. 1, p. 4-13.

Raine, J.I., Mildenhall, D.C., and Kennedy, E.M., 2005, New Zealand fossil spores and pollen; An illustrated catalogue: Institute of Geological and Nuclear Sciences Information Series 68, version 1. http:// 
www.gns.cri.nz/what/earthhist/fossils/spore_pollen/ catalog/index.htm

Reichart, G.J., Nortier, J., Versteegh, G., and Zachariasse, W.J., 2002, Periodical breakdown of the Arabian Sea oxygen minimum zone caused by deep convective mixing, in Clift, P.D., Kroon, D., Gaedicke, C., and Craig, J., eds., The tectonic and climatic evolution of the Arabian Sea region: Geological Society Special Publication 195, p. 407-419.

Riehle, J.R., Fleming, M.D., Molnia, B.F., Dover, J.H., Kelley, J.S., Miller, M.L., Nokleberg, W.J., Plafker, G., and Till, A.B., 1997, Digital shaded-relief image of Alaska: Reston, VA, U.S. Geological Survey, Miscellaneous investigation series Map I-2585.

Robison, V.D., Liro, L.M., Robinson, C.R., Dawson, W.C., and Russo, J.W., 1996, Integrated geochemistry, organic petrology, and sequence stratigraphy of the Triassic Shublik Formation, Tenneco Phoenix \#1 well, North Slope, Alaska, U.S.A.: Organic Geochemistry, v. 24, no. 2, p. 257-272.

Schuffert, J.D., Jahnke, R.A., Kastner, M., Leather, J., Sturz, A., and Wing, M.R., 1994, Rates of formation of modern phosphorite off western Mexico: Geochimica et Cosmochimica Acta, v. 58, no. 22, p. 5001-5010.

Shields, G., and Stille, P., 2001, Diagenetic constraints on the use of cerium anomalies as palaeoseawater redox proxies: an isotopic and REE study of Cambrian phosphorites: Chemical Geology, v. 175, no. 1-2, p. 29-48.

Sholkovitz, E.R., Shaw, T.J., and Schneider, D.L., 1992, The geochemistry of rare earth elements in the seasonally anoxic water column and porewaters of Chesapeake Bay, Geochimica et Cosmochimica Acta, v. 56, no. 9, p. 3389-3402.

Sholkovitz, E.R., Landing, W.M., and Lewis, B.L., 1994, Ocean particle chemistry; the fractionation of rare earth elements between suspended particles in seawater: Geochimica et Cosmochimica Acta, v. 58, no. 6, p. 1567-1579.

Stone, D.B., and Wallace, W.K., 1987, A geological framework of Alaska: Episodes, v. 10, no. 4, p. 283288.

Swift, D.J.P., Philips, S., and Thorne, J.A., 1991, Sedimentation on continental margins IV; lithofacies and depositional systems, in Swift, D.J.P., Oertel, G.F., Tillman, R.W., and Thorne, J.A., eds., Shelf sand and sandstone bodies; geometry, facies and sequence stratigraphy: International Association of Sedimentologists, Special Publication 14, p. 89-152.

Tailleur, I.L., 1973, Probable rift origin of the Canada Basin, in Pitcher, M.G., ed., Arctic Geology: American Association of Petroleum Geologists Memoir 19, p. 526-535.
Suess, E., and Thiede, J., eds., 1983, Coastal upwelling, its sediment record; Part A, responses of the sedimentary regime to present coastal upwelling: New York, Plenum Press, 594 p.

Tourtelot, H.A., and Tailleur, I.L., 1971, The Shublik Formation and adjacent stratigraphy in northeast Alaska; Description, minor elements, depositional environments and diagenesis: U.S. Geological Survey Open-File Report 71-284, 62 p.

Traverse, A., 1988, Paleopalynology: Boston, Unwin Hyman, 600 p.

Tschudy, R.H., and Scott, R.A., ed., 1969, Aspects of Palynology: New York, Wiley InterScience, 520 p.

Vail, P.R., Mitchum, Jr., R.M., and Thompson III, S., 1977, Seismic stratigraphy and global changes of sea level; Part 4, Global cycles of relative changes of sea level, in Payton, C.E., ed., Seismic stratigraphy; applications to hydrocarbon exploration: AAPG Memoir 26, p. 83-97.

Van Wagoner, J.C., Posamentier, H.W., Mitchum, R.M., Vail, P.R., Sarg, J.F., Loutit, T.S., and Hardenbol, J., 1988, An overview of the fundamentals of sequence stratigraphy and key definitions, in Wilgus, C.K., Hastings, B.S., Ross, C.A., Posamentier, H.W., Van Wagoner, J., and Kendall, C.G.St.C., eds., Sea-level changes: An integrated approach: SEPM Special Publication 42, p. 39-45.

Wallace, W.K., and Hanks, C.L., 1990, Structural provinces of the northeastern Brooks Range, Arctic National Wildlife Refuge, Alaska: AAPG Bulletin, v. 74, no. 7, p. 1100-1118.

Wang, K., Chatterton, B.D.E., Attrep Jr., M., Orth, C.J., 1993, Late Ordovician mass extinction in the Selwyn Basin, northwestern Canada; Geochemical, sedimentological, and paleontological evidence: Canadian Journal of Earth Science, v. 30, no. 9, p. 1870-1880.

Waples, D., 1981, Organic geochemistry for exploration geologists: Minneapolis, Minnesota, Burgess Publishing Company, $151 \mathrm{p}$.

Weimer, P., and Posamentier, H., eds., 1994, Siliciclastic sequence stratigraphy; Recent developments and applications: AAPG memoir 58, 492 p.

Wenger, L.M., and Baker, D.R., 1986, Variations in organic geochemistry of anoxic-oxic black shale-carbonate sequences in the Pennsylvanian of the Midcontinent, U.S.A.: Organic Geochemistry, v. 10, no. 1-3, p. 85-92.

Whalen, M.T., 1995, Barred basins; A model for eastern ocean basin carbonate platforms: Geology, v.23, no. 7, p. 625-628.

1996, Facies architecture of the Permian Park City Formation, Utah and Wyoming; implications for the paleogeography and oceanographic setting of western Pangea, in Longman, M.W., and Sonnenfeld, 
M.D., eds., Paleozoic systems of the Rocky Mountain region: Denver, Rocky Mountain Section SEPM, p. 355-378.

Whalen, M.T., Dumoulin, J.A., Lukasik, J.J., McGee, M.M., White, J.G., and Toendel, T.D., 2005, Carboniferous phosphorite deposition and carbonate platform drowning, Lisburne Group, central Brooks Range, Alaska: Geological Society of America Abstracts with Program, v. 37, no. 4, p. 93.
Wright, J., Schrader, H., and Holser, W.T., 1987, Paleoredox variations in ancient oceans recorded by rare earth elements in fossil apatite: Geochimica et Cosmochimica Acta, v. 51, no. 3, p. 631-644. 